Andrews University

Digital Commons @ Andrews University

1977

\title{
Home, the School of Love: A Seminar in Family Spiritual Enrichment
}

Robert Howard Cowan

Andrews University

Follow this and additional works at: https://digitalcommons.andrews.edu/dmin

Part of the Practical Theology Commons

\section{Recommended Citation}

Cowan, Robert Howard, "Home, the School of Love: A Seminar in Family Spiritual Enrichment" (1977).

Professional Dissertations DMin. 502.

https://dx.doi.org/10.32597/dmin/502

https://digitalcommons.andrews.edu/dmin/502

This Project Report is brought to you for free and open access by the Graduate Research at Digital Commons @ Andrews University. It has been accepted for inclusion in Professional Dissertations DMin by an authorized administrator of Digital Commons @ Andrews University. For more information, please contact repository@andrews.edu. 


\begin{abstract}
HOME, THE SCHOOL OF LOVE: A SEMINAR

IN FAMILY SPIRITUAL ENRICHMENT
\end{abstract}

\title{
by
}

Robert Howard Cowan

Chairperson: John Youngberg 


\title{
ABSTRACT OF GRADUATE STUDENT RESEARCH \\ Project
}

\author{
Andrews University
}

Theological Seminary

Title: HOME, THE SCHOOL OF LOVE: A SEMINAR IN FAMILY SPIRITUAL ENRICHMENT

Name of researcher: Robert Howard Cowan

Name and title of faculty adviser: John Youngberg Ed.D

Date completed: August 1977

\section{Problem}

The families of the Seventh-day Adventist Church must develop deepening love relationships with God, with each other, and with people outside their own homes if they are to fulfill the will of christ. Three factors may be hindering the development of love on these three levels: (1) a lack of understanding about what love really is, (2) a lack of understanding of how love develops in human and divine/human interrelationships, and (3) a lack of understanding that the home is the central focal point where this love is to be developed. 


\section{Methods}

The methods used involved three phases: (1) preparation, (2) presentation, and (3) evaluation. The preparation phase involved a select survey of contemporary literature in the field of family enrichment; becoming involved as a learner in several marriage and/or family enrichment seminars; and the preparation of a questionnaire, evaluation sheet, and seminar materials.

The presentation phase involved conducting two family spiritual enrichment seminars; one in Michigan and one in California.

The evaluation phase involved the analysis of questionnaire results and evaluation sheets, with a goal toward improving the seminar content and procedures and the personal skill of the leader in leading a seminar.

\section{$\underline{\text { Results }}$}

The majority of the seminar participants reported the seminar had been successful in meeting its objectives and in helping them to develop deeper love relationships on all three levels.

Suggestions for improvement included having more time for the seminar and having some sort of follow-up meetings after the seminar was over. 


\section{Conclusions}

The results of these two seminars suggest that since this family spiritual-enrichment seminar has been helpful in meeting the needs of some of the families in two Adventist churches, it might also be helpful in meeting the needs of some other Adventists elsewhere. Therefore, the following eight recommendations are made for the future: (1) at least one family seminar each year should be conducted by the leader in his home church, (2) regular follow-up meetings for seminar alumi should be provided, (3) these same materials should be used in marital and premarital counseling, (4) the leader should be available occasionally to conduct seminars away from his local church, if needed, (5) this format could be tried as a means of evangelism, (6) a family study group could be formed, (7) these materials should be offered for publication to permit other pastors or laymen to conduct these seminars, and (8) the leader should make family-life education a specialization in his ministry. 


\title{
Andrews Uniyersity \\ Seventh-day Adventist Theological Seminary
}

HOME, THE SCHOOL OF LOVE: A SEMINAR

IN FAMILY SPIRITUAL ENRICHMENT

\author{
A Project Report \\ Presented in Partial Fulfillment \\ of the Requirements for the Degree \\ Doctor of Ministry
}

by

Robert Howard Cowan

August 1977 

HOME, THE SCHOOL OF LOVE: A SEMINAR

IN FAMILY SPIRITUAL ENRICHMENT

A project report presented

in partial fulfillment of the requirements

for the degree

Doctor of Ministry

by

Robert Howard Cowan

APPROVAL BY THE COMMITTEE:

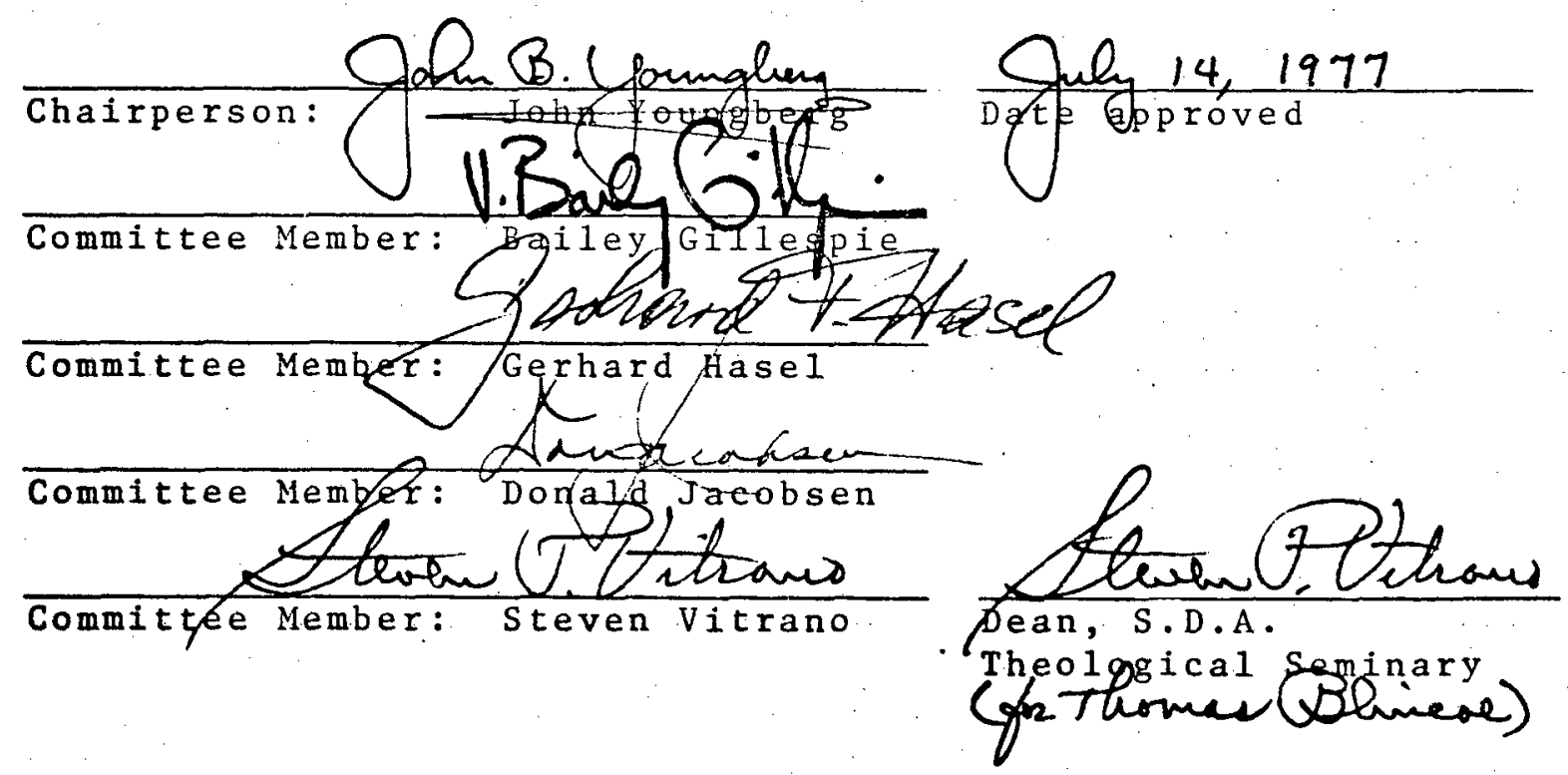


TABLE OF CONTENTS

LIST OF CHARTS . . . . . . . . . . . . . . xi

LIST OF TABLES . . . . . . . . . . . . . . . . . xii

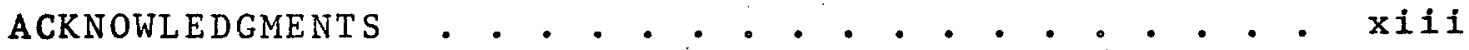

Chapter

I. INTRODUCTION . . . . . . . . . . . . . . .

Statement of the Problem . . . . . . . . 1

Justification of the Problem. . . . . . . 2

The Problem in Society . . . . . . . . . 2

The Influence of Family Problems on.

the Seventh-day Adventist Church . . . . 8

Assumptions and Implications... . . . . 10

Clarification of Terms Used . . . . . . 12

Love... . . . . . . . . . . . . 13

Home... . . . . . . . . . . . . 23

School. . . . . . . . . . . . . 24

Seminar . . . . . . . . . . . . . 24

Family ................. . . . . 24

Enrichment............... . . . 25

Image of God. . . . . . . . . . . . . 25

Research Design, Instrumentation, 26

and Populations Studied . . . . . . . . 26

II. A SELECT SURVEY OF CONTEMPORARY LITERATURE IN THE FIELD OF FAMILY ENRICHMENT . . . . . . . 28

Introduction . . . . . . . . . . . . . . 28

Premarital Preparation........... . . 28

Marriage Enrichment . . . . . . . . . . 31

Marriage Counseling . . . . . . . . . 36

Child Development and Training . . . . . . 39

Self-Esteem . . . . . . . . . . . 40

Discipline... . . . . . . . . . . . 42

Adult Education in Small Groups . . . . . . 47

Family Enrichment . . . . . . . . . 55

Communicaition............ . . . . 58

Some Distinctive Features of
Home, the School of Love. . . . . . . . 65

III. HOME, THE SCHOOL OF LOVE . . . . . . . . . . 67

Introduction .... . . . . . . . . . 67 
Love as a Part of the Image of God in Man.

The Loss and Restoration of Love as a

Part of the Image of God in Man ....

The Home as a School for the Development

IV. THE BENTON HARBOR SEMTNAR . . . . . . . . . . 87

Introduction... . . . . . . . . . . 87

Arranging for the Seminar . . . . . . . 87

Gaining Approval from the Benton

Harbor Church . . . . . . . . . 87

Staffing the Seminar . . . . . . . . . 88

Conducting the Seminar . . . . . . . . . . 90

Invitations . . . . . . . . . . . 90

Schedule... . . . . . . . . . . . 90

Format of the Seminar Meetings . . . . . 90

The Data Reported . . . . . . . . . . 99

Evaluation Sheets . . . . . . . . . . 99

Family Surveys . . . . . . . . . . . 101

V. THE HEMET SEMINAR . . . . . . . . . . . . 104

Introduction . . . . . . . . . . . . . . . 104

Functioning as a Consultant Compared

to Leading a Seminar in one's

Own Church............... . . 105

The Eight-day Format as Compared

to the Three-day Format . . . . . . . 107

The Advantages of the Eight-day

Seminar ............... . . 107

The Advantages of the Three-day

Seminar . . . . . . . . . . . 108

Differences in Resource People. . . . . . 108

Improvements in the Hemet Seminar

from Lessons Learned in the Benton

Harbor Seminar... . . . . . . . . 109

Age of Participants . . . . . . . . 109

Witnessing Module . . . . . . . . . . 109

Seminar Scheduling Procedure . . . . . . 110

Meeting Schedule... . . . . . . . . . 111

Subject Outine for Seminar Sessions . . . . 112

The Data Reported . . . . . . . . . . 123

Evaluation Sheets . . . . . . . . . 123

The Family Surveys... . . . . . . . 125

VI. SUMMARY, EVALUATION, AND RECOMMENDATIONS • . . 127

Summary . . . . . . . . . . . . . 127

Evaluation . . . . . . . . . . . . . . . 128

Evaluation Sheets . . . . . . . . . . 129

The Family Surveys . . . . . . . . . . 131

Seminar Leader's Self-evaluation. . . . . 133 
Learning goals for the leader..... 133

Learning goals for the church members . 135

Recommendations . . . . . . . . . . 136

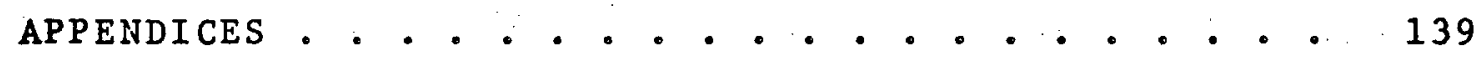

APPENDIX A . • . . . . . . . . . . . . . . 140

Additional Ellen G. White Quotations

on the Restoration of the Image of

God in Man.................. . . 141

APPENDIX B . . . . . . . . . . . . . . . . 143

Additional Ellen G. White Quotations

on Love ... . . . . . . . . . . . . . 144

APPENDIX C . . . . . . . . . . . . . . . . . 148

Additional Ellen G. White Quotations

on the Home as a Training School

For Love... . . . . . . . . . . . . 149

APPENDIX D . . • . . . . . . . . . . . . . 152

Additional Ellen G. White Quotations

on the Importance of the Home From the

Book The Adventist Home . . . . . . . 153

APPENDIX E . . . . . . . . . . . . . . . . 155

Some Samples of the Materials Used

in Conducting Family Spiritual

Enrichment Seminars . . . . . . . . . . . 156

SELECTED BIBLIOGRAPHY - . . . . . . . . . . . . 204

VITA SHEET . . . . . . . . . . . . . . . . . . 213 


\section{LIST OF CHARTS}

I. Introductory Meeting, Sabbath, November 16,1974 . . . . . . . . . . . 91

II. First Group Session, Sunday, November 17,1974 . . . . . . . . . . 92

III. Second Group Session, Monday, November 18,1974 . . . . . . . . . . . . 93

IV. Third Group Session, Tuesday, November 19,1974 . . . . . . . . . . . 94

V. Fourth Group Session, Wednesday,
November 20, 1974 . . . . . . . . . 95

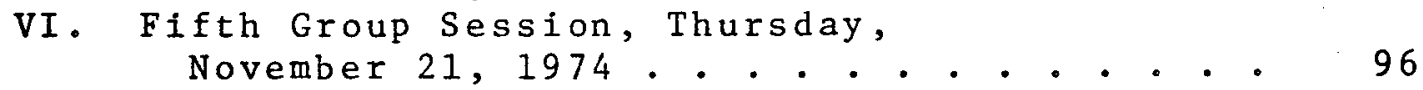

VII. Worship Service, Sabbath,
November 23,1974 . . . . . . . . . . . . . 97

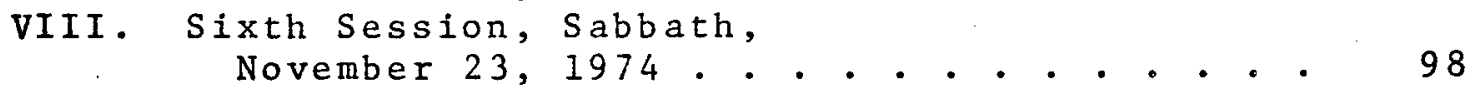

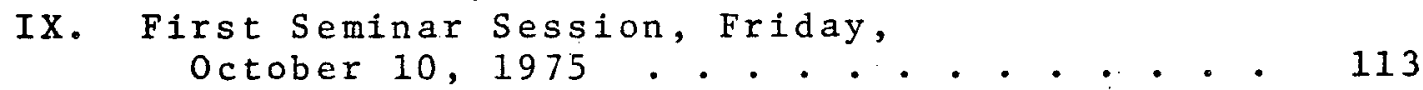

X. Second Seminar Session, Friday,
October 10,1975 . . . . . . . . . 114

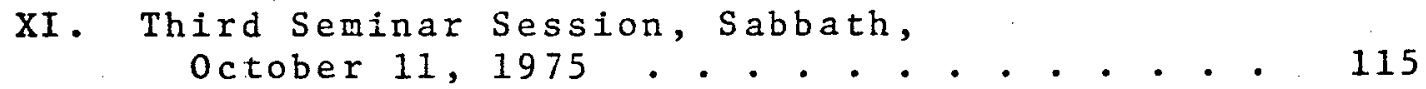

XII. Fourth Seminar Session, Sabbath, . . . . . . . . . . . . 116

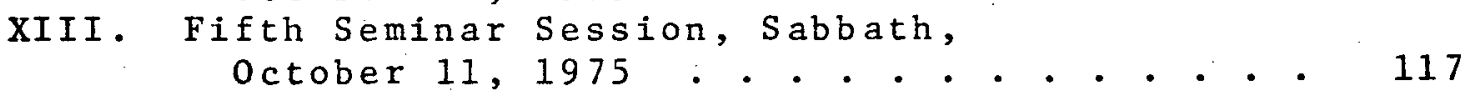

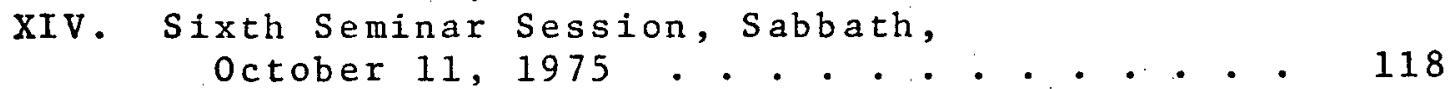

XV. Seventh Seminar Session, Sabbath,

XVI. Eighth Seminar Session, Saturday
night, october $11,1975 . .$.
. . . . . 120

XVII. Ninth Seminar Session, Sunday,
October 12,1975 . . . . . . . . . . 121

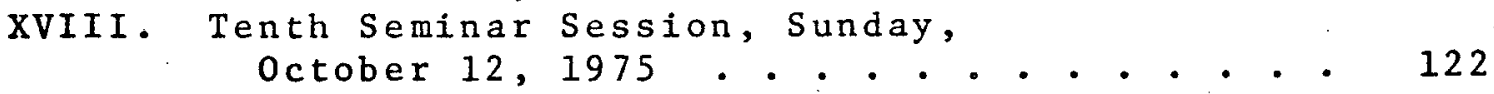


LIST OF TABLES

I. Observed Change From Pretests

to Posttests . . . . . . . . . . . . . 103

II: Observed Change From Pretests

to Postests................ 126 


\section{ACKNOWLEDGMENTS}

The help of many people has contributed toward the completion of this report. Special appreciation is hereby expressed to my project committee: Dr. John Youngberg, Chairman; Dr. Bailey Gillespie, Dr. Gerhard Hasel, Dr. Donald Jacobsen, Dr. Steven Vitrano; to Dr. Arnold Kurtz, the Chairman of the Doctor of Ministry program; to Mrs. Hazel Roller for typing the first draft of the paper; to Mrs. Joan Riese for typing the final draft; to Miss Ruth Ann Plue of Andrews University computing center for her help in analyzing the questionnaires; to the Southeastern California Conference of Seventh-day Adventists who granted me the necessary time and financial resources to complete this project; to my wife, Janet, and our children, Bobby and Michelle, who have encouraged their husband and $f$ ather to pursue this topic through to its ultimate completion in spite of the fact that it sometimes took him away from the family life about which he was reading and writing; and to my family of origin--my father, Howard Cowan; my mother, Isabe1 Downing; my sister, Joyce Laub; and my. brother, Michael Cowan--who were my first human teachers in what it means to be a family. 


\section{CHAPTER I}

\section{INTRODUCTION}

Family-life education is a rapidly growing interdisciplinary field of study. Since the writer of this project report is a Christian pastor, and not a sociologist, psychologist, or professional educator, he is concerned about helping families in the local church situation. Because his orientation is that of a commitment to the strengthening and improving of the family unit, his views offer a sharp contrast to some other contemporary writers who are suggesting that the family unit be dissolved as an institution. 1

\section{Statement of the Problem}

The problem that is being approached in this project report is a twofold problem having both an inward and an

$1_{\text {While some authors openly advocate the dissolution }}$ of the family unt, e.g., see David Cooper, The Death of the Family (New York: Pantheon Books, a division of Random House, 1970), others seriously challenge those who hold the conventional assumptions about the necessity of the nuclear family, the inherent nature of male and female sex-role differences, and the unchangeability of human nature, e.g., see Arlene S. Skolnick and Jerome H. Skolnick, Family In Transition (Boston, Mass.: Little; Brown and Co., 1971); David A. Shultz and Robert A. Wilson, eds., Readings on the Changing Family. (Englewood Cliffs, N.J.: Prentice-Hall, 1973); Norman Sheresky and Marya Mannes, Uncoupling: The Art of Coming Apart (New York: Viking Press, 1972); Edward Shorter, The Making of the Modern Family (New York: Basic Books, 1975). 
outward manifestation. The inward problem is that of unsatisfactory relationships between Seventh-day Adventist family members and God. The outward problem is that of unsatisfactory relationships within Seventh-day Adventist families. While the first problem relates to divine-human relationships, the second area has to do with human-interpersonal relationships.

\section{Justification of the Problem}

The awareness of this twofold problem did not come to the writer in a day. Instead it grew into his awareness during his first decade of pastoral ministry in the congregations he has served. The years since then have reinforced his determination to make a meaningful contribution in the Adventist church toward the solution of this problem of strained, fractured, and broken relationships.

\section{The Problem in Society}

Seventh-day Adventists are not the first group of people to experience problems in family relationships. The Biblical record is clear that the first human family had its share of problems, too. One example is that of a sibling murder when Cain killed his brother, Abel.

From then until now, all of human society has struggled with the problem of unsatisfactory human relationships, both inside and outside the family structure. Some people today are asking questions about the ability of the family to survive as an institution. A brief survey of 
recent thinking on this subject will illustrate this point of view. An editor for a religious book publisher writes of his concern for family survival in a recent issue of the Fuller Theological Seminary Alumni Newspaper (Pasadena, California) which was devoted to "The Family in the Christian Community."

Is there a future for the family? Or will the family soon become an antiquated vestige of the past like horse-drawn carriages and ice boxes in the kitchen?

An abundance of prophets of doom are running to and fro, predicting the end of the family as an

In the same issue, a professor of pastoral theology at Gordon-Conwell Theological Seminary in South Hamilton, Massachusetts, observes that "Today perhaps more than at any other time in human history, the nuclear family is under serious attack."2 As evidence for this statement he quotes a portion of David Cooper's book, The Death of the Family, and describes the quotation as a "disturbing and vitriolic attack on the family." 3

Newspaper and news magazine articles from the early 1970 s have often carried stories about experiments in marriage in such countries as Sweden, Denmark, and America, citing such free-wheeling ideas as group families, househusbands, unwed mothers, and trial marriages as evidences

${ }^{1}$ David A. Stoop, "Editorial," Theology, News and Notes 20 (December 1974):2.

${ }^{2}$ George Ensworth, Jr., "Biblical Foundations for the Family," Theology, News and Notes 20 (December 1974): 3 . ${ }^{3}$ Ibid. 
that the modern family structure is undergoing serious societal change. One such article, entitled "The American Family: Future Uncertain," is quoted in part here as an example.

"Can the family survive?" asks anthropologist Margaret Mead rhetorically. "Students in rebellion, the young people living in communes, unmarried couples living together call into question the very meaning and structure of the stable family unit as our society has known it." The family, says California Psychologist Richard Farson, "is now often without function. It is no longer necessarily the basic unit in our society."1

Five years later, another news weekly devoted thirteen pages to a special section discussing the same issues, two sentences of which are quoted here.

A turbulent era of experimentation and change is under way in the American family.

Marriage bonds are loosening under the strains of broad social and economic shifts in the nation at large--among them the quest for equality in the home and "fulfillment" in outside careers.2

The nearer the articles get to the present day,

the more open and flagrant become the attacks on the family. One outspoken critic of the family and of fidelity in marriage who openly advocates committing adultery says, "Sex with one's doctor can be rewarding as a 11 these case histories have demonstrated." 3

$1_{\text {Time, }}$ December $28,1970, \mathrm{p} .34$.

2"The American Family: Can it Survive Today's Shocks?" U.S. News \& World Report, October 27, 1975, p. 30 .

3Isobel Silden, "Should You Have Sex With Your Doctor?" Pageant 32 (January 1977) :48. 
Dr. Paul Popenoe, founder of the American Institute

of Family Relations, has sounded a warning about these trends.

"No society has ever survived after its family life deteriorated." 1

Urie Bronfenbrèner, a Cornell psychologist, regarding the signs of declining family stability in America, says:

One of the signs that a society is beginning to lose its vitality is that children cease to be central in the lives of people. If you want to turn society around, it's around children that you have the hope
of doing it. 2

Bruno Bettelheim, a professor of psychology and psychiatry at the University of Chicago, defined some of the factors which have resulted in dissension and disorganization in the family in a lecture he gave at Pacific Union College in Angwin, California (1976).

"An astonishing fact," said Bettelheim, "is that the average marriage is expected to last much longer than ever before." Two hundred years ago the average length of one marriage was 17 years but today the average length is 39 years because of increased life expectancy. "I submit to you," said Bettelheim, "that it is much easier to live successfully for 17 years than for 40 years."

In addition to longer marriages, there are also longer parent-child relationships. 3 ,

"Bettelheim also noted in this same lecture on "The Difficulty between Parents and Children in the Modern Family" that,

Girls mature physically much earlier than ever

$1_{\text {Time, }}$ December 28,1970, p. 34 .

2 Ibid., P. 37 .

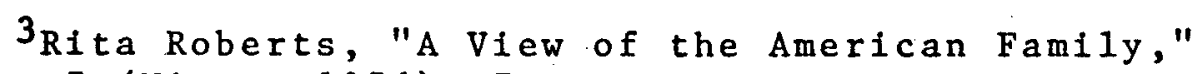
viewpoint 7 (Winter 1976) : 7 . 
before. In the 1700's menstruation began when girls reached an average age of 18 ; in 1900 the average age dropped to 14 ; today it is 12 . Although scientists are unsure of the reasons, a young girl's early physical maturity does create problems with sexual overtones that the average parent in the past did not have.1

Dr. Reuben Hill, a professor of sociology at the University of Minnesota, contributed an article entitled "The Family and Population Change" to a book on family life in which he identified six major changes in family structure and functions. According to Hill, the modern American family is changing

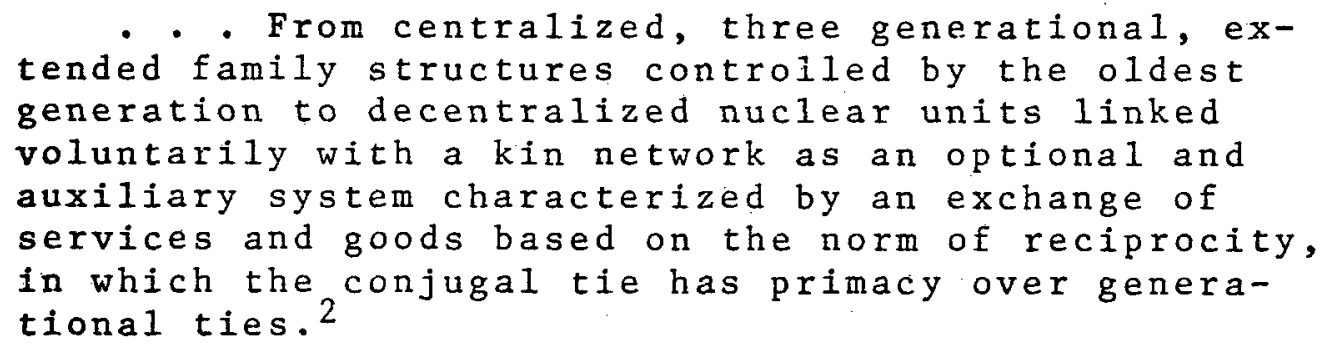
tended family structures controiled by the oldest generation to decentralized nuclear units linked voluntarily with a kin network as an optional and auxiliary system characterized by an exchange of services and goods based on the norm of reciprocity, in which the conjugal tie has primacy over generational ties. ${ }^{2}$

To say it more simply, whereas the family of yesterday was larger, with grandma and grandpa living in the same house with their children and grandchildren on a farm where they all depended on each other, today, mom, dad, and the kids live by themselves in the city independent of the influence of grandparents, and often independent even of each other.

\section{IIbid.}

2 Arthur A. Campbell et a1, eds., The Family in Transition, A Round Table Conference sponsored by the John E. Fogarty International Center for Advanced Studies in the Health Sciences, Proceeding No. 3, (Bethesda, Md.: National Institute of Health, 1969), p. 27. 
For those who believe in the sanctity and perpetuity of the family, it is encouraging to note that not all of what is being written today about family life in America is negative.

David Stoop, whose editorial was quoted in part ear1ier in this chapter, is one who sounds a positive note.

We hope this issue [of Theology, News and Notes] will help you raise your voice higher in the growing crescendo of the prophets of hope [for family survival].1

Bettelheim expresses hope that the family can adjust itself to a society in transition and still remain a significantly strong institution. He suggests this can best be accomplished as family members learn how to cope with problem solving in an atmosphere of love and acceptance.

Says Bettelheim:

Modern technological society has not only separated the child's activities--and therefore his life-from that of his parents, our population's mobility has put a great deal of physical distance between family members.

Since neither ties of work nor ties of place any longer bind us the only bond that can now hold families together is an emotional one. It is essential, therefore, when difficulties arise, that we refrain from blaming each other. We must instead accept problems as challenges to be met together, because it is only through trying to cope with these by our combined best efforts that we can regain the feeling that we truly belong to each other.2

One reason why so many family members today believe

\section{${ }^{1}$ stoop, p. 2 .}

${ }^{2}$ Bruno Bettelheim, "Recreating Family Life: The Means Are in Our Hands," Parents' Magazine \& Better Homemaking, October 1976 , p. 72 . 
their family is failing, according to Bettelheim, is their mistaken concept that good families never have any problems.

The worst impediment to a satisfying family life today is the conviction that it should be free of serious difficulties, and should run like a smoothlyworking machine. If the correct view prevailed--that when people live together this, in itself, creates problems--then it could be seen that the good family isn't one in which problems don't occur, but one in which the members work together to solve problems as they happen. 1

\section{The Influence of Family Problems on the Seventh-day Adventist Church}

The idea that only the non-Christian families in

America are in trouble, if it has ever been true, is no

longer true today. Christian and non-Christian family mem-

bers are both under great pressure from modern society to abandon their commitments to each other and let the family die like a sinking ship beneath the ocean waves of change.

For a Christian pastor to agree that such a sacred, God-ordained institution as the Christian family is in trouble is hard enough, but to go a step beyond that and admit that the families in his own denomination are in trouble is even more difficult. And the difficulty of admission increases as the circle is drawn closer to him personally by focusing the attention upon his own local congregation, extended family, or nuclear family.

He need not see the disintegration of "Christian" families as a crisis to his faith, but rather as an evidence of the priority the evil one places in his attack on 
marriage and the family. The Apostle Peter says: "Be sober, be vigilant; because your adversary the devil, as a roaring lion walketh about, seeking whom he may devour."1 since every person who is devoured by the devil is a member of someone's family, it is not difficult to see why the families of the church are affected also. However, the Christian pastor will desire to contest this battleground with the enemy, for the well being of his members and the glory of God Who chartered the marriage and family institutions.

This writer's observations as a minister have convinced him that families in the Seventh-day Adventist Church today are experiencing a divorce rate that is higher than ever before. In addition, he has come to realize that many Adventist families are experiencing growing unrest, unhappiness, and lack of fulfillment. These latter families may not experience a divorce, but they are certainly not happy. Some husbards and wives have stopped caring for or communicating with each other, if they ever really knew how to do either in the first place. Some parent-child relationships are so strained that both parents and children are relieved when the younger members of the family are old enough to move out and go away from home. Whether they go to a boarding school or college, get a job or get married is less important than that they leave. Some sibling relationships are so strained that brothers and sisters rarely say a kind

\section{$1_{1} \operatorname{Pet} \cdot 5: 8$}


word to each other, if they speak at all, except at mealtime when they say, "Please pass the salt." We must face the reality of the situation that serious problems exist in Seventh-day Adventist families and that no church is immune to the pervasive culture which surrounds it.

What therefore is the problem being addressed in this project? How can it be solved? The surface problem is the strained, fractured, and broken human relationships within the Adventist family. But the real problem doesn't stop there. It goes deeper than the problem of unhappy human relationships to its underlying causes which almost always have to do with problems in the sphere of divinehuman relationships. That is, whenever two or more people are not getting along well with each other, there is a high probability that one or more of them is having some degree of difficulty in getting along with God.

\section{Assumptions and Implications}

The writer states the following assumptions and their implications which are part of the philosophical framework from which he has worked.

1. God is an integral part of success or failure in building happy family relationships.

2. The giving and receiving of genuine love is an essential, if not the most essential, ingredient in building successful human, or divine-human relationships.

3. The family should be the first and the best 
place (but not the only place) to learn how to love both God and man.

4. The church can help families become better environments for learning how to love.

5. The seminar format is one means by which a church can help families grow spiritually.

6. When families grow in their love to God and for each other, one of the natural results will be a desire to bear witness of this inward change to other people outside the family circle.

The development of true love for both God and man is seen in this report as the most viable solution to the problems facing Seventh-day Adventist Christian families. It is further the approach of this report that the ideal place for true love to be developed is within the home. The church has both an opportunity and a responsibility to help its families grow spiritually. Therefore the writer has attempted to put together a seminar format in which small groups of Adventist families can be helped to learn how to love God and each other better.

As a natural outgrowth of developing greater love for God and for one's own kindred, the writer has anticipated that love for those outside the immediate family will also occur. To aid in the development of this awareness of love beyond the home circle, part of the seminar deals with the concept of the Christian's witness for Jesus Christ in the world. 
It is further anticipated that many, if not all, of the principles that will help Adventist families develop love for God, for each other, and for other people beyond their family. will apply to Christian families of other denominations also. As evidence that love for God and man is a universal Christian principle that transcends denominational barriers, this quotation is offered.

No matter how many good qualities we may have, however honorable and refined we may consider ourselves, if the soul is not baptized with the heavenly grace of love to God and one another, we are deficient in true goodness and unfit for heaven, where all is love and unity. 1

The writer therefore hopes this project report will contribute toward the betterment of mankind in general and Adventist families in particular, with the long range view of assisting. in the preparation of men and women, boys and girls to spend eternity with the redeemed of all ages of this earth's history enjoying the presence of the Godhead.

\section{Clarification of Terms Used}

The terms to be clarified, as used in this paper are love, home, school, seminar, family, enrichment, and image of God. The clarifications are not considered to be final; rather they are suggestions toward a better understanding of the above-mentioned words. Since love is the

1Ellen G. White, Testimonies for the Church, 9 vols. (Mountain View, Calif.: Pacific Press Pub.Assn., 1948), 4: 224 . 
central issue, more space will be given to its clarification than will be given to any of the other words discussed here.

\section{Love}

To understand the meaning of the word "love" as used in this paper requires a brief investigation into the biblical usages of some of the words translated in English as "love" from both the $01 \mathrm{~d}$ and the New Testaments. The $01 \mathrm{~d}$ Testament usages will be explored first followed by the New Testament undergirding for the word "love."

The first 01d Testament word to be considered here is 'ahabah. Regarding this word Siegfried H. Horn suggests:

The OT word generally translated "love", is 'ahabah and the verb translated "to love" is 'ahab. These terms comprehend love in its widest scope, from God's love for the righteous (Ps 146:8, etc.) man's love to God (Dt 11:1; Ps 116:1, etc.), and for the things of God (Ps 119:97, etc.), a man's love for his family and friends (Gen 22:2;24:67; Lev 19:18, etc.), to the illegitimate love born of passion ( $2 \mathrm{Sa} 13: 1 ; 1 \mathrm{Ki} 11: 1$, etc.). 1

Norman Snaith maintains that there are

three main elements for the understanding of Hebrew 'ahabah (love). First God's love for Israel is an unconditional sovereign love. Second, Israel's love for God is a conditioned, dutiful love, showing itself in the proper fulfillment of God's requirements as laid down in the covenant. Third, Israel must obey, not only because he must, but also because he must "love, and with al1 his will

${ }^{1}$ Siegfried H. Horn, Seventh-day Adventist Bible Dictionary, (Washington, D.C.: Review and Herald Pub. Assn., 1960), s.v. "Love." 
(nephesh, desire, self), and with all his strength."1 This broad, general word for love then embraces a wide concept of love with many different specific meanings or applications. Another word used in the old Testament that has a narrower or more restricted usage is the term chesed. Snaith observes that the Hebrew word chesed is translated in the English versions "with few exceptions, by 'mercy, loving-kindness,' the latter being a rendering which we owe in the first place to Miles Coverdale. Luther used the word Gnade, his New Testament rendering of charis (Grace)." 2

The same author points out that a distinction must be made between chesed and 'ahabah, since both mean "love". The difference lies in the fact that chesed, in all its varied shades of meaning, is conditional upon there being a covenant. . . on the other hand 'ahabah is unconditional love... 'Ahabah is the cause of the covenant; chesed is the means of its continuance. Thus 'ahabah is God's Election-Love, whilst chesed is His Covenant-Love. ${ }^{3}$

In this quotation, Snaith defines love in the light of the concept of coveriant with His people Israel, which is a recurring motif throughout the $01 \mathrm{~d}$ Testament.

George Buttrick sees a harmony between love and Law in the old Testament because of the covenant relationship between God and Israel. Says he:

${ }^{1}$ Norman Henry Snaith, The Distinctive Ideas of the old Testament (Philadelphia: Westminster Press, 1946), p. 172 .

$$
\begin{aligned}
& { }^{2} \text { Ibid., p. } 118 . \\
& 3_{\text {Ibid., }}, 119 .
\end{aligned}
$$


- . Those who love Yahweh are those who keep his commandments (Ex 20:6; Dt 5:10; 7:9; 11:1; Neh 1:5; Dan 9:4; etc.). There is in the OT, therefore, no antithesis between love and 1 aw. The love of God is primary, and man loves both God and man in response to God's love. But the life of love is a life lived out in the relationship of the covenant. The law is the gift of God's love in order that man may have a framework in which he orders his devoted obedience. 1

Gerhard Kittel, in discussing the word "love" in relationship to the covenant, refers to the usage of the word "love" in the book of Deuteronomy. Says Kitte1:

- . the thought of love in Dt serves predominantly to undergird the thought of election and covenant. The irrational singularity of love is presented, therefore, in a way which is strictly formal and ineffective. Thus we are told that Yahweh has chosen Israel of all the nations on earth as His peculiar people. It was not because Israel was more numerous than others, on the contrary, it is the smallest of all peoples--but because He loved Israel that He bound Himself. . to it (Dt $7: 6 \mathrm{ff}) .2$

Snaith concurs with kittel here when he writes that

God chose Israel because He willed to choose them, Deuteronomy vii. 6-8. It was not because of any necessity laid upon Him from outside. It was all of His own free, unfettered, and sovereign will. The realization of this is essential to the understanding of both $01 d$ and New Testaments. ${ }^{3}$

The same author makes four important points in the following quotation about God's love in relationship to God's covenant with Israel.

${ }^{1}$ George Arthur Buttrick et. a1., eds., The Interpreter's Dictionary of the Bible, 4 vols. (New York: Abingdon Press, 1962), 3:168.

${ }^{2}$ Gerhard Kittel, ed., Theological Dictionary of the New Testament, 10 vo1s. (Grand Rapids, Mich.: Wm. B. Eerdmans Pub. Co., 1964), 1:33.

${ }^{3}$ Snaith, p. 137 . 
Firstly, Jehovah existed before Israel. Secondly, if He once existed without them, He could do so again. Thirdly, if He chose them, He could also reject them. Fourthly, He was different from other gods in the demands He made upon His people as their part in the Covenant. These four points are of the utmost importance. Without them, Israel's religion could never have grown to what it actually did become. The development is wholly wrapped up with the special relations between God and His people. These relations were centered in, and sumed up in the Covenant. The Covenant involved these four special and peculiar conditions. 1

God's steady and persistent love for Israel in spite of its waywardness is extremely important, for snaith, to an understanding of the 0ld Testament concept of God's love.

Wonderful as is His love for His covenant-people, His steady persistence in it is more wonderful still. The most important of all the distinctive ideas of the 01d Testament is God's steady and extraordinary persistence in continuing to love wayward Israel in spite of Israel's insistent waywardness. ${ }^{2}$

In harmony with Snaith, Merrill C. Tenney emphasizes God's "steadfast love" as an attribute of God that is both permanent and enduring.

Though love itself is an attribute (of God), it in turn consists of attributes. It is through these attributes, functional characteristics, and fruits, that love is portrayed in the Bible rather than through definitive terms. From the earliest patriarchal records (Gn 24:12), the durability and permanence of love is portrayed in the continual recurrence of the phrase "steadfast love". It occurs in nearly every book in the OT, totaling at least 171 times in the RSV, and is particularly frequent in the Psalms and the later writings. It appears seven times in 2 Chronicles $(1: 8 ; 5: 13 ; 6: 14$; etc.), and twenty-six times in Psalm 136. This is a thanksgiving psalm for the Lord's great deeds on behalf of

$$
\begin{aligned}
& { }^{1} \text { Ibid., pp. } 136,137 . \\
& { }^{2} \text { Ibid., p. } 129 .
\end{aligned}
$$


His people, in which the response is, "For his steadfast love endures forever." The same quality appears in Jeremiah when God promises joyful restoration from Babylonian exile, declaring to Israel, "I have loved you with an everlasting love; therefore I have continued my faithfulness to you" ( Jer $31: 3) .1$

George Buttrick stresses the importance of under-

standing the old Testament idea of love before one can understand the New Testament ideas of love and grace. Says he:

Love in the $O T$ is the basic character of the relationship between persons, a relationship with the qualities of devotion, loyalty, intimate knowledge, and responsibility. It is not simply an emotion but is the total quality of relationship. In its personal character, love is closely related to the sexual realm, even when the subject is God's love.. And the "person" may be collective, as in the case of God's love for Israel as a whole. In a11 cases, love is the force which both initiates and maintains relationships, be it among persons or between. God and man. The OT idea of the love of God is decisive for the NT ideas of love and grace. It includes the relationships of friendship, sex, covenant, loyalty, kindness, and sometimes mercy or pity. 2

Tenney writes further about God's love when he states

that

- . The revelation of diety as the God of love is a distinctive of the Judeo-Christian religions. . . - . Love in divine-human relationships and in interhuman relationships is at the heart of Christian life and teachings. . . - Love emanates from God ( 1 John 4:7 f.). . . Love is also a prerequisite to being a good citizen, a good neighbor, or a good husband or wife or parents. 3

${ }^{1}$ Merrill $c$. Tenney, ed., The Zondervan Pictoral Encyclopedia of the Bible, 5 vols. (Grand Rapids, Mich.: Zondervan Pub. House, 1975), 3:990.

2 But,trick, $3: 164$.

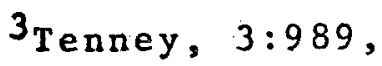


Beyond the covenant and election motifs in the old

Testament, there are other 111ustrations of God's love

which depict Him as a Husband or as a Father. Both of these

concepts can be found, for example, in the book of Hosea,

as is observed by Kittel:

- - Love as a basic motif in Yahweh's dealings

with His people seems first to have been experienced

by Hosea, so far as we can see... . Hosea clearly

perceives at the depths of the thought of the elec-

tion and the covenant the spontaneous love of the

acting God. . . He [Hosea] depicts this God as a man

who against custom, legal sense and reason woos a

worthless woman (Hos. 3:1). Hosea has to love the adultress as Yahweh loves the children of Israel. . . The prophet is to take a harlot to wife, for only a marriage which is nonsensical in the eyes of men and dishonoring to the husband can really give a faithful picture of the relationship of Yahweh to the land of Israel (Hos. 1:2). . . He [Hosea] pulls down the structure of the covenant theory in order to lay bare the foundation in the love of God... .

With the same tenderness and depth Hosea introduces the thought of God's love in other motifs which cause us to think of fatherly love, although the actual terms father and son are perhaps deliberately avoided and we are simply given a picture of the fatherly instructor who is disappointed but who for this very reason loves the more passionately. 1

Snath also discusses God's love in Hosea and sees

there clear evidence of a love that is both "sure" and "unswerving."

Hosea's own domestic experience taught him what chesed could mean to Jehovah. Because of his own attitude to his wayward wife, he came to know that the chesed of God meant steadfast determination to be true to His share of the Covenant obligation whatever Israel did on her part. Hosea's love for Gomer-bath-Diblaim was so strong and sure that not all her adulteries could kill it. He realized that Jehovah's love for Israel was at least

${ }^{1}$ Kitte1, $1: 31,32$. 
as sure and strong as his own love for his wife. Jehovah's love was both a "sure love" and a "love unswerving." 1

Collin Brown also refers to Hosea in his discussion of the meaning of God's love. After referring to Hos 11:8

(and the following verses) where God is portrayed as a

Father who does not wish to give up His son, Ephraim, he writes :

This description by Hosea of the passionate and zealous love of God is unprecedented in its boldness. For, according to Hosea, the God-ness of God does not express itself in destructive power, but in tender and compasionate love, which precedes any responsive human love, and which suffers through the faithlessness of his people. $(6: 4)$ and does not hand them over to ultimate ruin. 2

God as a Father loving His child is also seen in Mal 1:6; $3: 17$.

Tenney also clearly perceives God's love in the husband-wife motif in Hosea.

Even in Israel's apostasy, God revealed to the prophet Hosea His undying love for His chosen people. Divine compassion that would not let Israel go was realistically portrayed through Hosea in the domestic drama of a faithful husband's love to an unfaithful wife (Hos $1: 2 f ; 3: 1-5) \cdot 3$

The last 01d Testament motif of God's love that will be mentioned here is that of Isa 49:15 which portrays God's love as more enduring than a mother's love: "Can a woman forget her sucking child, that she should not have compasion on the son of her womb? Yea, they may forget,

${ }^{1}$ Snaith, pp. 140,141 .

2 Collin Brown, ed., The New International Dictionary of the New Testament, 3 vols. (Grand Rapids, Mich.: Zondervan Pub. House, 1976), 2:540.

${ }^{3}$ Tenney, $3: 991$. 
yet will I not forget thee."

Moving on now to the New Testament undergirding of

love, it is first observed that John agrees with what the

01d Testament has been saying all along, that "God is love."

(1. Jn 4:8).

The Apostle Paul goes a step further as he identi-

fies some important attributes about what love really is.

Love is very patient and kind, never jealous or envious, never boastful or proud, never haughty or selfish or rude. Love does not demand its own way. It is not irritable or touchy. It does not hold grudges and will hardly even notice when others do it wrong. It is never glad about injustice, but rejoices whenever truth wins out. If you love someone you will be loyal to him no matter what the cost. You will always believe in him, always expect the best of him, and always stand your ground in defending him. 1

Earl Palmer observes that while it is true that

men learn something about love in early childhood, and seek it all the rest of their lives, yet "there is hardly a word or an experience that is as misunderstood, or as partially understood as this one." 2

We have said so much and have written so much about love, it would seem by now that we should have clarified, if not exhausted, the subject.... When we consider God's love, we are still usually confused. We seem to have an especially difficult time understanding love as a way of living. And surely not enough has been said to help us clearly understand the unique, 1 ife-changing kind of love that unfolds in the New Testament. 3

${ }^{1}$ Cor 13:4-7, The Living Bible, paraphrased, (Wheaton, I11.: Tyndale House Publishers, 1972), p. 927.

2Earl F. Palmer, Love Has Its Reasons: An Inquiry into New Testament Love (Waco, Tex.: Word Books, Pub., 1977), p. 22 .

3 Ibid. 
According to Sherrill, the experience of love "is so rich with meaning that no one word can ever include it all."1

- . we who speak English must press this one word into service as a symbol for what is, in fact, a galaxy of experiences. . . But the Greek language . . made good use of the terms Eros and Agape.. - love. . Eros is love whose motive is to enhance the status of the self. within a relationship. . agape is love whose motive is to enhance the status of the one loved. ${ }^{2}$

Siegfried Horn identifies phileo as another New Testament word that is translated 'to love,' 'to like,' 'to kiss,' [and notes that] it occurs much less frequently than agapao." 3 He also provides a helpful distinction between the meanings of agapao and phileo which is reported here:

The love represented by phileo is affectionate or sentimental love based more on feelings and emotions than the love represented by agapao. Examples of its usage are $\mathrm{Mt} 6: 5 ; 10: 37 ; 23: \overline{6 ; \mathrm{Jn}} 11: 3,36$, etc. This kind of love is never commanded in the Bible, for it is more or less spontaneous, as is a parent's love for his child and a child's love for his parents (Mt 10:37); but the love represented by agapao is commanded (Mt 5:44; Eph 5:25; etc.). This is possible because agape is a principle, and may be described as a love of respect and esteem, a love bringing into play the higher powers of the mind and intelligence. It is this kind of love that the Christian is to exercise even toward his enemies (Mt 5:44). That is, he is to treat his enemies with proper respect, but he is not commanded to have a warm emotional affection toward them, such as would be required of him if he were commanded to show them the love represented by phileo. 4

$1_{\text {Lewis }} \mathrm{J}$. Sherrill, Guilt and Redemption, rev. ed. (Richmond, Virginia: C. D. Deans, 1957), p. 97.

2 Ibid.

3orn, s.v. "Love.".

4 Ibid. 
In Schuller's view,

- . It takes great courage to love. For love means involvement, the risk of disapointment, the chance of exposing our intimate life to another person. Only the person who is really deeply selftrusting has the courage to love on this vulnerable leve 1 . 1

One of the amazing things about God is His ability

to love His created beings in such a vulnerable way. His

love for man is revealed best in the life and death of

Christ. "For God so loved the world, that he gave his only

begotten Son, that whosoever believeth in him should not

perish, but have everlasting life." 2

Sherrill. says that the cross of Christ reveals what

"the character of God is. God is Agape--Love--and the cross not only demonstrates what that means, but also demonstrates that an inexhaustible supply of it is available in our universe. 3

Love begins with God's initiative and finds its fulfillment in man's response. Human love is awakened by God's love. 4 Love includes both vertical and horizontal dimensions-communion with God and community with persons. In its simplest essence, love is togetherness and belonging.

Love, then, as used in this paper, is that

$1_{\text {Robert H. Schuller, Self-Love: the Dynamic Force }}$ of Success (New York: Hawthorn Books, 1969), p. 192 .

$2 \mathrm{Jn} 3: 16$.

${ }^{3}$ sherril1, p. 170 .

${ }^{4}$ Ellen G. White, The Desire of Ages (Mountain View, Calif.: Pacific Press Pub.Assn., 1940), p. 22. 
multi-faceted positive attribute of God's character which is Inwardly experienced by the Christian and outwardly expressed by him in his relationships with others (human or divine). Love involves a total response of oneself as a whole person. As such, love involves the emotions, the will, and the physical being, but it is not limited to any one of these three.

Love is a principle, 1 a decision-event, 2 and a description of $\operatorname{God}^{3}$ all at the same time. It is not dependent on moods 4 for its expression. It has beneficient characteristics which are without peer among human experiences. "Real love is unconditional, uncalculating, non-selective and non-judgmental." 5

\section{Home}

A home is more than a building, it is an environment of love, acceptance, and encouragement--a place where people, as a family, interact with each other. But is is also a training ground for interaction in a wider circle of contacts--with God, people, and things. It includes the concepts of sacrifice, giving, and discipline. The people who live in a home are more than occupants--they are participants in life together.

\footnotetext{
1White, Testimonies, $2: 169$. 


\section{School}

A school is a place and an atmosphere in which learning happens. It has no restrictions as to time or place. Instead, it occurs in a variety of times and places. Learning will take place in settings that are formal and structured or informal and unstructured.

\section{Seminar}

A seminar is a special kind of school that convenes for a relatively short time period. It offers many opportunities for student-teacher interaction. It is a taskoriented activity that may have learning or behavior modification as its goal. The objectives of a seminar will determine what is expected of the participants.

\section{Family}

Ideally, a family is a group of people, usually three or more, who are related to each other by legal or blood ties, usually living within close physical proximity to one another, and having a basic attitude of mutual trust and helpfulness toward each other. One's family of origin is his first nuclear family. The family he establishes at his marriage is his second nuclear family. 1 when other relatives are included, whether they live near or far, they are the extended family.

${ }^{1}$ Also called the conjugal family or the family of procreation. 
In virtually all societies, the family is the institutional structure carrying the responsibility for replenishing societal membership as well as the protection, physical maintenance, socialization, and social placement of the young. Closely allied with the family is the institution of marriage, which serves to legitimatize parenthood and to ensure the offspring will be recognized and supported. "In many respects, the family is the mediating agent of the culture. It is the chief agency for transmitting values and attitudes." 1

\section{Enrichment}

The term enrichment as used here does not connote the increase of material wealth. Instead it describes spiritual growth within people's lives. It includes the development of increased maturity, awareness, and understanding about life as Christian families.

\section{Image of God}

The image of God, as used in this paper, means that likeness or similarity to God which is present in any given human being at any given time in history. God's image in man was nearly lost due to man's fall into sin. One of the goals of the plan of redemption is the restoration of the image of God in man. "The central theme of the Bible, the

${ }^{1}$ Donald H. Blocker, Developmental Counseling, (New York: Ronald Press Co., 1966), p. 189. 
theme about which every other in the whole book clusters, is the redemption plan, the restoration in the human soul of the image of God."I

\section{Research Design, Instrumentation, and Populations Studied}

The research design for these seminars was to offer the seminar to a small group of fifty people or less by a self-selecting method. That is, the seminar would be announced and let those who wished to attend.

The instruments used were a Family Survey and an evaluation sheet. The Family Survey questionnaire was designed by the writer in an attempt to determine attitudes and present experience of seminar participants with regard to their love for God, love for family, and love for those outside the family.2

This survey was given as a pretest the first night of the seminar to all participants, and the same survey (minus the biographical information) was given at the end of the seminar as a posttest. The data were key punched and fed into a computer for analysis.

The computer-printout results were compared to see if participants showed any change in attitude or present experience that might be partly attributable to the trainIng in the seminar.

1Ellen G. White, Education (Mountain View, Calif.: Pacific Press Pub. Assn., 1952), P. 125.

${ }^{2}$ see appendix E for sample of Family survey. 
In addition, an evaluation sheet asking for suggestions for improvement was completed by each participant at the last meeting of the seminar. ${ }^{1}$

The popliations studied were Seventh-day Adventists who voluntarily attended a week-long seminar in Benton Harbor, Michigan and a weekend seminar at Pine Springs Ranch, an Adventist Retreat Center, near Hemet, California.

Chapter IV will report on the Benton Harbor Seminar and chapter $V$, the Hemet Seminar. These are being reported separately for three reasons: (1) the first seminar was held in another pastor's church while the second seminar was held for the writer's own church members; (2) the resource persons and some of the content was different in the two seminars; and (3) the week-long style is different than the weekend style.

${ }^{1}$ See appendix $E$ for sample for Evaluation Sheet. 
CHAP TER I I

\section{A SELECT SLRVEY OF CONTEMPORARY LITERATURE IN THE FIELD OF FAMILY ENRICHMENT}

\section{Introduction}

Books on the subject of family life continue to proliferate. Libraries and bookstores are well-stocked with'literature in this field, much of it being written from a sociological or psychological point of view.

In this study, an attempt is made to survey a selection of currently available literature related to the subject of family enrichment. No claim is made that this survey is exhaustive or complete, but contributions of the literature which have undergirded this project are highlighted. The materials are organized under the following headings: (1) pre-marital preparation, (2) marriage enrichment, (3) marriage counseling, (4) child development and training, (5) adult education in small groups, (6) family enrichment, and (7) the distinctive features of "Home, the School of Love."

\section{Premarital Preparation}

It is recognized in family-life literature that marriages which begin we 11 have a greater chance of 
succeeding than those that begin poorly. To help young people prepare for marriage, Arthur Spalding, 1 and Harold Shryock ${ }^{2}$ have prepared books on this topic. Since then many books have been written by authors of various philosophical orientations--even as high-school or college textbooks for courses in preparation for marriage--which provide a general overview of the family in America. ${ }^{3}$ other works are directed more specifically at sex education for couples contemplating marriage. ${ }^{4}$

A cursory survey of book titles on marriage and the family from the early period following World War II suggests a strong sociological emphasis. In contrast to these, however, are the books written by David Mace, an author from the postwar era who writes from a Christian philosophical perspective. His concept of marriage originates in the old

${ }^{1}$ Arthur W. Spalding, Love, Courtship and Marriage (Washington, D.C.: Review and Herald Pub. Assn., 1929).

2 Harold Shryock, Happiness for Husbands and Wives (Washington, D.C.: Review and Herald Pub. Assn., 1949).

${ }^{3}$ See Francis E. Merril1, Courtship and Marriage rev. and exp. ed. (New York: Henry Holt \& Co., 1959); Paul H. Landis, Your Marriage and Family Living, 2 d ed. (St. Louis, Mo.: McGraw-Hil1 Book Co., 1954); and Judson T. Landis and Mary G. Landis, Building a Successful Marriage, 6 th ed. (Englewood Cliffs, N.J.: Prentice-Ha11, 1973).

${ }^{4}$ See Hugo G. Beigel, Encyclopedia of Sex Education (New York: Wm. Penn Pub. Corp., 1952); S. A. Lewin and John Gilmore, Sex Without Fear rev. ed. (New York: Medical Research Press, 1962); and Ralph G. Eckert, Sex Attitudes in the Home (New York: Association Press, Popular Library Edition, 1963). 
Testament design for the Hebrew people.1 Mace stresses the point that marriage involves an extended and complex process of interpersonal adjustment.2. He also suggests that some of this adjustment can be made before the wedding day through proper premarital preparation.

While premarital preparation should include a broad spectrum of principles and attitudes, some parents feel unqualified to supply their children with information on sexual adjustment in marriage. Most parents could read some books about premarital preparedness and thereby improve their ability to help their children be ready for the establishment of their own homes. One author on premarital preparation, Charlie Shedd, wrote letters, which he later printed as books that provide some of the most interesting reading in the field from a Christian perspective to his daughter ${ }^{3}$ and to his son. 4

Tim and Beverly La Haye who have written on sex from a Christian standpoint, stress that expressing one's love physically does not come naturally. It must be

${ }^{1}$ David R. Mace, Hebrew Marriage (London: Epworth Press, 1953).

2 David R. Mace, Success in Marriage (Nashville, Tenn.: Abingdon Press, 1958), p. 23.

${ }^{3}$ Charlie W. Shedd, Letters to Karen: On Keeping Love in Marriage (Nashville, Tenn.: Abingdon Press, Spire Books, 1973).

${ }^{4}$ Charlie W. Shedd, Letters to Philip: On How to Treat a Woman (01d Tappan, N.J.: Fleming H. Revell Co., Spire Books, 1973). 
learned.1 For that reason they say: "A couple must seriously study this subject just prior to marriage, and then after their marriage they can begin their practice to learn satisfying techniques." 2

\section{Marriage Enrichment}

Marriage enrichment generally has the goal of strengthening successful marriages. Its focus is more on the prevention of serious marital conflict than it is on the solving of deep-seated problems at the eruption of a crisis. This latter area is more in the domain of marriage counseling.

Love between the marriage partners is the most often emphasized theme in the literature on marriage enrichment. Loving is viewed by Erich Fromm as more an art than a sentiment that can be easily indulged in by anyone. It results from maturation and the development of one's total personality. Hence the truly loving person is a rarity because so few are really mature. 3

For Spa1ding,

Love is the greatest power in the world. It is the greatest power in the home, where the problems of conduct are first encountered. No

${ }^{1}$ Tim La Haye and Beverly La Haye, The Act of Marriage: The Beauty of Sexual Love (Grand Rapids, Mich.: Zondervan Pub. House, 1976).

IIbid., p. 59 .

${ }^{3}$ See Erich Fromm, The Art of Loving (New York:

Harper \& Row, Pub., Bantam Books, 1963). 
stern command, no weight of authority, can accomplish, in the formation of character and the direction of will, what love will accomplish. 1

other authors such as Mace and Fagal, agree that couples of deep religious faith

- . see their love as partaking of, and reflecting back, the love of God. They see their union as ordained within the unfolding of divine purpose which embraces them and all mankind. . .

Their happiness is deep and enduring precisely because they never make happiness their first objective. For one of 1 ife's strange but inexorable paradoxes is that the pursuit of happiness is a self-defeating activity. ${ }^{2}$

Now as of old, the true inner bond that sustains a marriage is love--not a superficial sentiment, but a deep sustained, outgoing concern for the loved one. 3

If in marriage each partner can seek out the best in the other, enlarging encouragingly on these good points, he or she will receive rewarding love and life-long appreciation in return. Expressions of confidence and faith always bring out the very best in another. Since love thrives on these positive virtues, use them 1 avish 1 y. 4

In another place, Mace, a co-founder of ACME, 5

stresses the importance of coping adequately with the pressures in the rapidiy changing society during the early years of marriage to help build loving relationships (which he believes to be the basis of a "good" family) by identifying

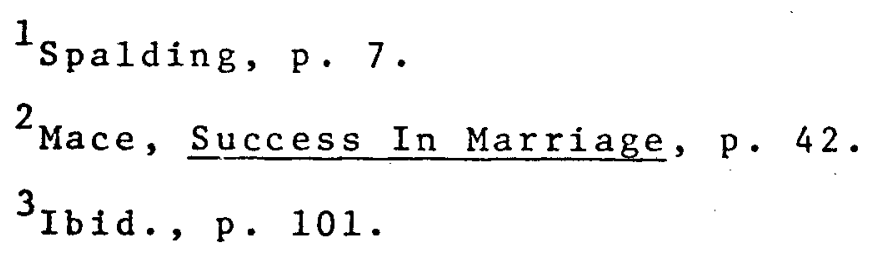

${ }^{5} \mathrm{ACME}$ is an acronym for the Association of Couples for Marriage Enrichment. 
six ways of preventing a marital crisis: (1) later marriage,

(2) later parenthood, (3) help in early marital adjustment,

(4) "staggering" husband-wife vocational goals, (5) family

clusters, and (6) marriage and family enrichment. 1

While the early years of marriage are very important in building love relationships, the importance of the middle and later years of a couple's life together must not be overlooked. A husband-wife team emphasize this last point and suggest:

The vast majority of married couples can, on their own achieve more satisfying relatedness, providing they are willing to pay the price of selfinvestment and mutual effort over an extended period. (Italics mine.) $)^{2}$

Marriage is the most difficult and the most demanding, but also the most potentially rewarding of all human relationships, because it is potentially the most intimate. Because it is the most intimate, it also holds the greatest potential for conflict. ${ }^{3}$

Marriage is described by Erickson and Hogan as "the on1y we11-known, long-term collaborative relationship."4 As such, marriage has four characteristics: "It is a voluntary; permanent; exclusive; and goal-oriented relationship."5 This intimate relationship of marriage is greatly

${ }^{1}$ David R. Mace, "Making Marriage Work," Parents" Magazine \& Better Homemaking, October $1976, \mathrm{p} .18$.

${ }^{2}$ Howard J. Clinebell, Jr. and Charlotte H. Clinebe11, The Intimate Marriage (New York: Harper and Row, Pub., $1970)$, p. 11 .

${ }^{3}$ Ibid., p. 96 .

${ }^{4}$ Gerald D. Erickson and Terrance P. Hogan, eds., Family Therapy, An Introduction to Theory and Technique (Monterey, Calif.: Brooks/Cole Pub.Co., 1972), p. 7 . 
influenced by certain factors called "dynamics" by Ernest

Ligon and Leona Smith ${ }^{1}$ who look upon the husband (and

father) as the cornerstone of the family. It is the wife, however, who creates the climate in the home which permits the husband to develop the necessary skilis, to achieve that role we11. It is the husband's influence that determines his wife's emotional outlook, be it temperamental or sparkling. By these examples, it can be seen that relationships are influenced by dynamics and spouses influence each other's dynamics.

Another author, who agrees that the man is the head of the house, insists that to have a happy Christian home the husband must really get involved with his wife and children. He suggests that "one reason men have lost the respect of their families is because they have become spectators in the family situation." 2

While Williams sees the husband as the initiator and aggressor in all areas of the marriage relationship and the wife as the responder, he believes "it takes the whole family working together to help each other to mature in love." 3

${ }^{1}$ See Ernest Mayfield Ligon and Leona. Jones Smith The Marriage Climate: A Book of Home Dynamics (St. Louis, Mo.: Bethany Press, 1963); For a study manual based on this book that can be used in group sessions, write to: Union College Character Research Project, 207 State St., Schenectady, New York, 12305.

${ }^{2}$ H. Page Williams, Do Yourself a Favor: Love your Wife (Plainfield, New Jersey: Logos International, 1973), P. 5 .

${ }^{3}$ Ibid., p . 33 . 
Williams believes that the most important gifts a man can give to his wife and children are his time, attention, appreciation, and understanding--not his money. The theme of his book is Eph 5:28: "This is how husbands should treat their wives, loving them as part of themselves. For since a man and his wife are now one, a man is really doing himself a favor and loving himself when he loves his wife."l Most authors surveyed here agree with Tim La Haye that "A happy home doesn't just happen." 2 But only the Christian authors agree with La Haye's concept of how a home can be happy. "It is the result of two things: proper adjustment to each other and incorporation into daily life of the principles of marriage outlined by God in the Bible." 3

Another author who stresses the importance of love in marriage is Dennis Guernsey, who identifies three facts about mature love based on 1 Jn $3: 16-18$ :

First, love is a giving of yourself irrespective of whether or not there are feelings attached. . . .

The second fact that hit me was that mature love seeks to practical1y and demonstrably meet the other person's needs. . .

Finally, a third truth struck me. Mature love relies not on good thoughts and tender words to demonstrate its reality. Instead it relies upon

1 The Living Bible.

${ }^{2}$ Tim La Haye, How To Be Happy Though Married (Wheaton, I11.: Tyndale House Pub., 1976), p. 9 .

${ }^{3}$ Ibid. 
actions and sincere practice. 1

James Dobson indicates there is a great need for men to understand their wives if the homes of America are going to be truly happy.

- too many men do not understand the emotional needs of their wives. . . women have needs which men do not comprehend. It is this breakdown of understanding, that has motivated this book and its title: . . . 2

Some additional resource information is available

from the Marriage Encounter Resource Comminity in local

Catholic parishes which are participating in the Marriage Encounter movement. Marriage enrichment material is only a part of the literature in this field. A large contribution to the body of research available is information concerning major crises in family life.

\section{Marriage Counseling}

Once a family's problems have advanced to the crisis point, marriage counseling becomes more necessary than enrichment. The family members need to be referred to a competent marriage counselor either individually or together. In an effort to more adequately prepare physicians to provide counseling, the University of Pennsylvania School of Medicine provided a five-year experiment in communicating information and attitudes on marriage and family living to

${ }^{1}$ Dennis Guernsey, Thoroughly Married (Waco, Tex.: Word Books, Pub., 1976), P P. 24-26.

2 James Dobson, What Wives Wish Their Husbands Knew about Women (Wheaton, I11.: Tyndale House Pub., 1975), P. 13 . 
their senior medical students. The stated goal of the experiment was

- . to make available to professional persons working intimately with people, and to the intelligent layman who as husband, wife, or parent is personally involved in close human relationships, material which has proved itself to be informative, stimulating, and practically useful in understanding and helping people with their development and with their problems. 1

Paul Tournier suggests that one of the most impor-

tant goals of marriage counseling is to help people understand each other. This requires careful 1 istening on the part of the counselor and the family members because the person who is listened to feels understood.

In order really to understand, we need to listen, not to reply. We need to listen long and attentively.2

The essential part of psychotherapy is listening, long and passionate listening, with love and respect and with a real effort at understanding. 3

A great deal of time must be taken in order to build a true marriage. . . A deep encounter rarely takes place in a few moments. It must be ${ }_{4}$ prepared for by hours of careful drawing together. ${ }^{4}$

It is quite clear that between love and understanding there is a very close link. It is so close that we never know where the one ends and the other begins, nor which of the two is the cause or the effect. He who feels understood feels loved, one who feels loved, feels sure of being understood. 5

${ }^{1}$ Emily Hartshorne Mudd and Aron Krich, eds., Man and Wife (New York: W. W. Norton \& Co., 1957), p. xxi.

${ }^{2}$ Paul Tournier, To Understand Each Other (Richmond, Va.: John Knox Press, 1967), P. 25.

$$
{ }^{3} \text { Ibid., p. 50. } \quad{ }^{4} \text { Ibid., p. 18. }{ }^{5} \text { Ibid., p. } 28 .
$$


The importance of developing mature love as one of the goals in marriage counseling is further emphasized by William Glasser who places love at the top of the list of psychological needs.

First is the need to love and be loved. In all its forms, ranging from friendship through mother love, family love, and conjugal love, this need drives us to continuous activity in search of satisfaction. From birth to old age we need to love and be loved. Throughout our lives, our health and our happiness will depend upon our ability to do so. To either love or to allow ourselves to be loved is not enough; we must do both. When we cannot satisfy our total need for love, we will without fail. suffer and react with many familiar psychological symptoms, from mild discomfort through anxiety and depression to complete withdrawal from the world around us.

Equal in importance to the need for love is the need to feel that we are worthwhile both to ourselves and to others. 1

One procedure for counseling with married couples is to follow a study manul that was designed for use by marriage counselors and couples together, such as the one written by James R. Hine. It has two parts-one for the husband and one for the wife--which provide worksheets and questionnaires intended to assit in analyzing the good and bad points of the marriage. Hine hopes that couples will discover more good than bad points, and the marriage relationship will improve. His goal is to help stop the rise in the divorce rate or even "to reverse the trend altogether." 2

${ }^{1}$ William B. Glasser, Reality Therapy (New York:

Harper \& Row, Pub., 1965), pp. 9-10.

2 James R. Hine, Alternative to Divorce (Danville,

I11.: Interstate Printers \& Pub., 1957), p. iv. 


\section{Child Development and Training}

One pair of writers, Fagal and Fagal, suggests that - - parenthood is a more important career than being the greatest artist, sculptor, author, or musician in the land. If these spend years and much effort acquiring skill in their chosen fields, a parent should expect to work with even more diligence and care in developing in a "human soul the likeness of the Divine."

Another writer, Koller, marvels at what little train-

ing is offered people to become effective parents.

What is astounding to some, but true, is the minimal or relative neglect of preparations for parenthood in the United States, in sharp contrast to the elaborate preparations, strategies, and efforts that go into entering marriage. ${ }^{2}$

Many married couples get along fine with each other

until their first child is born. With the arrival of the third member of the family, however, the potential for parental conflict over proper discipline and child training is introduced. With the addition of each new child the chances for conflict increase. If married couples were better prepared to understand child development and training, some of these areas of conflict could be more easily solved. Hence the need is observed for helping parents in the church grow in their understanding of children.

Parents would do well to read first a general book

${ }^{1}$ Fagal and Fagal, p. 41.

${ }^{2}$ Marvin R. Koller, Families, A Multigenerationa 1 Approach (New York: McGraw-Hi11 Book Co., 1974), p. 263 . 
on psychology. 1 Next they would do well to read something on child psychology. Justin Pikunas, a professor of psychology at the University of Detroit, has contributed a book which helps in understanding a child's psychological development from prenatal influences through senescence. ${ }^{2}$ From there, the parents may wish to study other areas of child training which concern them. Some authors limit their discussions to a few years of the child's life. 3 other authors have written books that concentrate more on subject areas than on chronological development. Two of these subject areas that will be reviewed next are selfesteem and discipline.

\section{Self-Esteem}

Self-esteem is an important subject because it is very easy for adults to lower a child's self-esteem by the way the adult relates to the child. Parental caution is needed to ensure the development of proper self-esteem in a child.

Strommen states that "it is well to observe that

${ }^{1}$ see Percival M. Symonds, Dynamic Psychology (New York: Appleton-Century-Crofts, 1949).

2 Justin Pikunas, Human Development: A Science of Growth (New York: McGraw-Hil1 Book Co., 1969), p. v.

${ }^{3}$ See Genevieve Millet ed., Guiding Your Child from 5 to 12 (New York: Parents' Magazine Enterprises, 1965); and Bertrand Williams, The Christian Boy's Problems, 4 th ed. (Grand Rapids, Mich.: Zondervan Pub. House, 1945). 
low self-esteem is passed on in families." 1 Therefore he concludes that:

Fostering self-esteem is an important goal for home and church. Given a congenial atmosphere and reaffirming adults, youth can change their selfperceptions and gain a new outlook on life. The awareness that one is loved by God and man can be encouraged. 2

Schuller also emphasizes the importance of selfesteem, which he says is closely related to self-love, selfworth, self-confidence, and self-image. ${ }^{3}$

Dobson observes that the world offers self-esteem by measuring a child's beauty, intelligence, wealth, and athletic ability. Those who lack these qualities develop strong feelings of inferiority and inadequacy. The Christian concept offers self-worth on an entirely different basis, maintains Dobson.

The healthy self-concept which Christ taught, then, involves neither haughtiness and pride nor. inferiority and worthlessness. It is one of humble reverence for God and every member of His human family. We are to see our fellowman as neither better nor worse than ourselves; rather we are to love them as ourselves, and that prescription puts the entire matter of self-worth into its proper perspective. 4

Most writers agree that self-esteem is best learned by a child in an atmosphere of love in the home.

Love is the basis for emotional security and

${ }^{1}$ Merton P. Strommen, Five Cries of Youth (New York: Harper \& Row, Pub., 1974), p. 26.
2 Ibid., p. 12 .
${ }^{3}$ schuller, p. 52 .
${ }^{4}$ James Dobson, Hide or Seek (01d Tappen, N.J.:

Fleming H. Revell Co., 1974), p. 159. 
stability in the individual. It is love from parents that helps to establish the secure personality. in infancy...

Love is the basis for effective personality development. The finest individuals are those who have been nourished in an atmosphere of love. 1

The findings of the psychology of personality indicate that fatherly love is the best possible motivation about which to integrate one's personality. Furthermore, fatherly love is a type of motivation which can be sustained. It is not subject to the fluctuations which most motivations undergo. It is based on a strong instinctive drive in human nature, and therefore can be easily taught to the child.2

\section{Discipline}

Regarding the importance of home training, Ligon and Smith say, religious and character education in the home are the "greatest source of impregnable strength." 3 They also maintain that "the home is an indispensable force without which the other [good influences] are usually ineffective. " 4

Glasser also emphasizes the need for an atmosphere of love in the home and suggests that discipline and love must go together.

Children ordinarily learn by means of a loving relationship with responsible parents, an involvement which implies parental teaching and parental

${ }^{1}$ symonds, p. 357 .

${ }^{2}$ Ernest Ligon, The Psychology of Personality (New York: Macmillan Co., 1944), p. 63.

${ }^{3}$ Ligon and Smith, The Marriage Climate, p. 204. ${ }^{4}$ Ibid., p. 239 . 
example. In addition, responsibility is taught by responsible relatives, teachers, ministers, and friends with whom they become involved. The responsible parent creates the necessary involvement with his child and teaches him responsibility through the proper combination of love and discipline. 1

Discipline and love, for Glasser, are not mutua11y exclusive alternatives, but parts of the same whole. "Discipline must always have within it the element of love."2

Josephine Edwards agrees with this point of view.

Children need a lot of loving at the turningout-the-light time. They need a lot of loving every minute. Love is the balm which heals the wounds of the world. 3

With regard to loving discipline, Cooper writes:

Children actually feel deprived if their parents do not correct them. Most youngsters flourish on loving discipline. It is a solid proof to a child-on the important level of the subconscious--that he is loved and cared about. Even teen-agers, we are told by the behavioral experts, want to be told when they make mistakes. 4

Josephine Edwards suggests some other good points on child discipline that are worthy of consideration. "One of the greatest requisites in discipline is that the punishment fit the offense."5 "A beautiful and holy character is dependent upon obedience."6. "Reward and praise obedience, and punish disobedience every time. Never make an exception."7

$$
\begin{aligned}
& { }^{1} \text { Glasser, p. } 16 . \quad 2 \text { Ibid., p. } 19 . \\
& { }^{3} \text { Josephine C. Edwards, Children Can Be Taught }
\end{aligned}
$$
(Nashville, Tenn.: Southern Pub. Assn., 1960), p. 37.

${ }^{4}$ Douglas Cooper, Living God's Love (Mountain View, Ca1if.: Pacific Press Pub. Assn., 1975), P. 117.

$$
{ }^{5} \text { Edwards, p. 39. }{ }^{6} \text { Ibid., p. 27. }{ }^{7} \text { Ibid., p. } 30 .
$$


Behavior modification by positive reinforcement is suggested by Edwards in the last quotation above, even though she does not use those terms, and it is reiterated below. "If children can see gains and results; if they can get warm praise, encouragement, and appreciation, they will run their legs off to help you."l

Edwards views children as friends of parents and teachers. "The a11-important thing is to have the friendship, love and confidence of the children committed to our care." 2

Ligon and Smith emphasize this last point also. "You discipline only those children who make themselves your disciples. The key to successful discipline therefore, is not how, when or whether you punish, but how to win and keep the child's discipleship."3

All parents are faced with daily decisions. with regard to child training. One author offers his book as "a practical guide" offering "concrete suggestions and preferred solutions for dealing with" these daily situations. He also claims that his book "sets forth basic principles to guide parents in living with children in mutual respect and dignity. $" 4$

${ }^{1}$ Ibid., p. $21 . \quad 2$ Ibid., p. 63.

${ }^{2}$ Ligon and Smith, . p. 55 .

$3_{\text {Haim G. Ginot, Between Parent and Child (New }}$

York: The Macmillan Co., Avon Books, 1965), p.xiv. 
Some authors are quite permissive and liberal in their attitudes toward child training. One example is Fitzhugh Dodson, a psychologist from Redondo Beach, California, who founded the La Primera Preschool. While he gives some helpful hints to fathers in one of his books, there are several areas in which his views differ sharply from less permissive, more conservative authors. He is against censoring what movies, $\mathrm{TV}$ shows, or books his children view; ${ }^{1}$ he regards masturbation as normal and accepted; ${ }^{2}$ he is opposed to sending high-school teenagers away to boarding schools; 3 and he suggests fathers should acknowledge having romantic and sexual feelings toward their teenage daughters but should keep these feelings to themselves. 4

Thomas Gordon is another author, whose attitudes toward child training and discipline are somewhat permissive. He has written several books on improving human relationships, including one on parent-child relationships.

Gordon, referring to Carl Rogers' book ClientCentered Therapy, admits "This book contains the origins of much of Dr. Gordon's philosophy and basic attitudes about persons." 5

Although Gordon does not specifically label his book

${ }^{1}$ Fitzhugh Dodson, How to Father (New York: New American Library, Signet Books, 1975), p. 203.

2Ibid., p. 232. ${ }^{3}$ Ibid., p. 260. ${ }^{4}$ Ibid., p. 271.

${ }^{5}$ Thomas Gordon, P.E.T.: Parent Effectiveness Training (New York: Peter H. Wyden, Plume Books, 1975), p. 329 . 
sociological or psychological in approach, he does identify 1t as "our humanistic philosophy."l His logic for training people for effectiveness is basically the same whether he is working with parents, teachers, school principals, leaders in industry, youth workers, or any other authority figure. He says,". - for a relationship to change in any significant way, he who holds the power must change." 2

Gordon really views his training method as". . People Effectiveness Training. . . based on a theory of human relationships that is applicable to any and a 11 relationships between people, not only to the parent-child relationship."3

The essence of Gordon's approach can be summarized by the following quotations.

How conflicts are resolved is probably the most critical factor in parent-child relationships. Unfortunately, most parents try to resolve them by using only two basic approaches, both of which are ineffective and harmful to the child as well as the relationship. 4

In P.E.T. we refer to the two "win-1ose" approaches to conflict resolution simply as Method I and Method'II [In Method I, the parent wins and the child loses; in Method II, the child wins and the parent loses]. Each involves one person winning and the gther losing--one gets his way and the other does not.

It comes as a revelation to parents, locked in by tradition to either of the "win-lose" power methods of resolving conflicts, that they do have an alternative. Almost without exception, parents are relieved to learn that there is a third method....

$$
\begin{aligned}
& { }^{1} \text { Ibid., p.xv. }{ }^{2} \text { Ibid. } \quad 3^{3} \text { Ibid., p. xii. } \\
& { }^{4} \text { Ibid., p. 149. 5Ibid., p. } 153 .
\end{aligned}
$$


The alternative is the "no-lose" method of resolving conflicts--where nobody loses. In P.E.T. we call it Method III. 1

Method III, then, is a method by which each unique parent and his unique child can solve each of their unique conflicts by finding their own unique solutions acceptable to both. 2

While much of what Gordon suggests is good and helpful, it is a more permissive approach to child training than some authors with a distinctively Christian approach can accept.

For example, James Dobson warns that the childmanagement philosophies of the past twenty years that advocate tolerance and permissiveness are unworkable and illogical in solving conflicts that involve rejection of parental authority by the child.

- . many we11-meaning specialists have waved the banner of tolerance, but offered no solution for defiance. They have stressed the importance of parental understanding of the child, and $I$ concur, but we need to.. . know when to punish, how to set limits, and what behavior to inhibit. This disciplinary activity must occur within the framework of love and affection, which is often.difficult for the parent who views these roles as contradictory. 3

\section{Adult Education in Small Groups}

Some authors discuss this topic from the viewpoint of business management. The pastor, on the other hand, is working with a volunteer organization (the church), and it

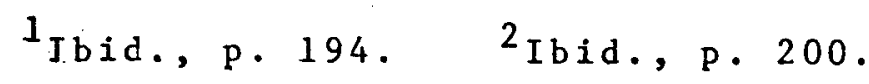

${ }^{3}$ James Dobson, Dare to Discipline (Wheaton, I11.: Tyndale House Pub., 1971 ), p. 13 . 
poses some different kinds of problems than does the business community. Still, some of the principles and concepts in the field of business can be applied to the church.

Richard Walton suggests that confrontations on all

levels among superiors and subordinates in industry can be helped toward a solution by a knowledgeable third-party consultant. He calls the end result "conflict resolution."

We increasingly understand that psychological and social energy is tied up in suppressing conflict, that conflicts not confronted may be played out in. indirect and destructive ways, and that the differences that underlie interpersonal conflict often represent diversity or complementarity of significant potential value to the organization. An interpersonal or organizational system that can acknowledge and effectively confront its internal conflicts has a greater capacity to innovate and adapt. 1

One book suggests handling conflicts openly in order to solve them in church groups.

- . it is blind obedience to the norm (especially prevalent in churches) that conflict is wrong or unchristian that sends individuals scurrying to the woods when conflict may be imminent. The problem with conflict, in most situations, is not that it will be destructive of the group--probably just the opposite is true--but its occurrence disregards the group norm that conflict is a no-no. Persons who try to deal openly with conflict are placed on the list of those to be avoided, shunned and cast out. In the minds of church members, any conflict is conflict gone awry. This group norm is highly debilitating to the life of the group because it gets in the way of possibilities for growth, change, and development. 2

${ }^{1}$ Richard E. Walton, Interpersonal Peacemaking: Confrontation and Third-Party Consultation (Reading, Mass: : Addison-Wesley Pub. Co., 1969), p. v.

${ }^{2}$ speed Leas and Paul Kittlaus, Church Fights: Managing Conflict in the Local Church (Philadelphia: Westminster Press, 1974), p. 13. 
Another author who recognizes the potential for conflict in local church groups writes: "From the first moment a young pastor steps into the pulpit or presides at a board meeting he is caught in the cross fire of conflicting expectations for the ministry."1

Since the role of a pastor is perceived in different ways by different people, a pastor should expect some misunderstanding and criticism when starting something new, like conflict resolution in small groups. If he doesn't feel able to cope with certain criticism in this new area of group leadership, he had better not start a smal1-group ministry in his church. If he does decide the possibilities of success are worth the risk of criticism, however, there are books available that offer some help.

For example, Robert $C$. Leslie in Sliaring Groups in the Church suggests that intimate group life fills an important gap in the lives of church members today that has been opened up by the increasing impersonalization in human relationships in modern secular culture.

Leslie sees the Biblical basis for the small intimate sharing group in the example of Jesus Christ and His twelve disciples who spent three and a half years in close contact with each other. Leslie believes that small sharing

${ }^{1}$ Donald P. Smith, clergy in the Cross Fire: Coping with Role Conflicts in the Ministry (Philadelphia: Westminster Press, 1974), p: 13 . 
groups offer "the best hope for church renewal."1

Clyde Reid's book Groups Alive--Church Alive

addresses itself to the effective use of small groups in the local church. He suggests that ". . the average church anywhere can be greatly strengthened by the proper use of the power of the small group." 2

one reason why small groups of church members meeting together offer hope for church renewal is the present lack of involvement by a significant number of members in the life and work of the church throughout the week without involvement in small groups. For too many, church is a place where people go one morning a week and then forget the other six and a half days. This problem is not unique to modern times, however. Ellen White wrote of similar conditions prevailing in some Adventist churches in the twelve years prior to 1900 when her sixth volume of the Testimonies for the Church was first printed.

Today a large part of those who compose our congregations are dead in trespasses and sins. They come and go like the door upon its hinges. For years they have complacently listened to the most solemn, soul-stirring truths, but they have not put them into practice. 3

${ }^{1}$ Robert C. Leslie, Sharing Groups in the Church: An Invitation to Involvement (Nashville, Tenn.: Abingdon Press, 1971), p. 7 .

2 (New York: Harper \& Row, Pub., 1969), p. 11 .

${ }^{3}$ White, Testimonies for the church, $6: 426$. 
Eyery soul should take an active part in advancing the cause of God. Whatever our calling, as Christians we have a work to do in making christ known to the world. We are to be missionaries, having for our chief aim the winning of souls to Christ. 1

Yet there are many people in the church whose concepts of the term missionary are limited to someone who works for Christ in a foreign country or to an activity which is reserved for doctors and ministers. Such a concept, however, is far too narrow.

These persons need first to be taught and disciplined at home. True faith and love for christ would create in them a most earnest desire to save souls right at home. . .

Let those who desire to work for God begin at home, in their own household, in their own neighborhood, among their own friends. Here they will find a favorable missionary field. This home missionary work is a test, revealing their ability or inability for service in a wider field.2

Since the church as a caring community is considered by many to be more easily discerned in a smallgroup setting, small groups are seen as helping to meet the need in the church for the renewal of spiritual life. It is hoped, therefore, that the present seminar may become a part of the solution for spiritually complacent Adventist families.

The impersonalization and depersonalization of our society has struck deeply into the life of the church and robbed us of our heart and warmth. To love Jesus' way, we have to really know and really care about one another as persons. It is precisely the awareness of lost contact with others that has

$$
{ }^{1} \text { Ibid., p. 427. } \quad{ }^{2} \text { Ibid., pp. 427-28. }
$$


led so many to join or form groups. 1

One reason why the cocktail lounge is so eagerly patronized in America today is because it has been filling a need that isn't being met in the home, at work, or at church. In today's society, bartenders and hairdressers perform a function not unlike the minister, counselor, or psychologist as listeners and sounding boards for the release of the tensions and anxieties of their customers. One writer suggests that the renewal of the church today is centering in the "rediscovery of the lay ministry and smal1 group fellowship." 2 Another writer, who sees the small group as a significant adjunct to the church, says,

The conclusion I've come to over the years is simple. The small groups of Christians meeting together can succeed--or fail. There is no magic in the "small group" itself, but when in that smaller group we experience the meeting of the Body of Christ for Ministry, exciting and positive things do happen. 3

He continues by clarifying the relationship he sees

between small groups and corporate worship in the church.

Does the small group replace the church? Not at a11! The small group should never be viewed as a replacement for the congregational gathering. Nor is small group Bible study a substitute for preaching the Word. The healthy church has both the smallgroup-type activity and a strong corporate ministry

${ }^{1}$ Lawrence 0. Richards, Sixty-nine Ways to Start A Study Group and Keep it Growing (Grand Rapids, Mich.: Zondervan Pub. House, 1973), p. 13 .

2 Bruce Larson, Groups That Work (Grand Rapids, Mich.: Zondervan Pub. House, 1967), p. 23.

${ }^{3}$ Richards, p. 8 . 
of worship and Bible teachings. ${ }^{1}$

While small groups for Bible study are one form groups in the church will take, the possiblity of a counseling group led by a capable pastor or laymen is another. Merle Ohlsen suggests that couselors ought to understand the dynamics of therapeutic groups. They also ought ". . to recognize and use the therapeutic forces within a counseling group, to facilitate changes in their clients' behavior, and to help clients learn to assist others while they obtain assistance for themselves." 2

Significantly, some small groups naturally occur in the church and these can be utilized to deepen spirituality instead of arranging contrived or artificial groupings. These natural groups are families. Other nonfamily groups in the church may be helpful and even necessary for lonely or isolated adults, and seminars can be arranged to aid in directing human lives constructively. This report suggests, however, that the family is God's answer to the expressed need of so many in American society today--fulfilling the desire to know and to be known, to understand and to be understood, to give and to receive love. It was God who established the family in Eden. He preserved it in the flood, and He emphasizes it throughout human history as is recorded by His inspired authors. From this point of view,

\footnotetext{
$1_{\text {Ibid., p. } 15 .}$

${ }^{2}$ Merle M. Ohlsen, Group Counseling (New York: Holt
} Rinehart and Winston, 1970$)$, p. ix. 
the family is God's ideal human structure in which primary group intergenerational love relationships are to be experienced.

If small-group family seminars can help to awaken the Adventist Church to the potential of the Christian family today, the time invested will be well spent. But these seminars should not be considered substitutes for the family. Rather they are designed as helping agencies for the family.

The growing body of literature on church growth also has something to say about working in groups and for groups, especially for family groups, in evangelizing people in America and around the world.

Donald McGavran and Win Arn say:

- . If you can win a whole family, it is better than if you pull someone out of the family... . I can illustrate it in the sunday School movement in America. If a church brings in only children, many of them are going to fall away. But if the entire family can be reached as a unit, the stability of the converts will be much greater. 1

The First Baptist Church in Dallas, Texas, pastored by Dr. Wally Amos Criswell, has 15,000 members. It also has one of the ten largest Sunday Schools in America.

When Dr. Criswell first came [in 1944] the congregation was made up of many middle aged teachers and older folks. A massive drive was put on to attract young couples to the downtown church. . . The largest group joining the church week by week is

${ }^{1}$ Donald A. McGavran and Win Arn, How to Grow A Church (Glendale, Calif.: G/L Pub., Regal Books, 1974), pp. 33-34. 
still composed of young families. 1

Overseas, the church growth emphasis should also be on winning families, according to Donald McGavran, referring

to Africa as an example.

The strong sense of community, the tribalism which is the life of Africans, makes group accessions available to speed sound church growth. A trickle of converts, each ostracized by his family as he is baptized, is unnecessary in Africa. ${ }^{2}$

\section{Family Enrichment}

In a discussion of family enrichment such as this,

it must be recognized that not all families are alike.

Marvin Koller, a sociology professor at Kent State University, recognizes the wide variety and diversity among

families in the following quotation.

It would be relatively easy to deal with family if it were a unique, simple social form. But such is not the case. Instead, an almost endless variety of families exists. There are families composed of single.parents and their dependent offspring; childless couples; both parents with one to a dozen or more children; unmarried brothers and sisters trying to make a home for themselves in the absence of both parents; and young, middle-aged, or elderly couples struggling for existence.

There are "other" qualities that bring about variations in families. Some families are rural and some are urban. Some are deeply immersed in ethnic, religious, or racial experiences and others are not. Some are impoverished and others live at

${ }^{1}$ Elmer Towns, The Ten Largest Sunday Schools, and What Makes Them Grow (Grand Rapids, Mich.: Baker Book House, 1969), p. 40 .

2 Donald A. McGavran, How Churches Grow (New York: Friendship Press, 1970), p. 7 . 
the peak of prestige and opulence, with a myriad varlations in between. Some have members who have been educated at the highest formal levels, while others have members who are illiterate. Some families are happy and content with their circumstances. Others are frustrated by conditions beyond their control. Some are at peace, others are at odds with the current social order.

For which family variant are we preparing, or should we be preparing, in family life study? In this text, we will emphasize that no ideal family, satisfactory to all, has yet been found or devised. Instead, there are families that have both strengths and weaknesses, abilities and disabilities, while individual family members try to follow some dimly defined model. Whatever models we choose, families of almost infinite variety will emerge, and these remain our central concern. 1

Some authors approach family enrichment more from the viewpoint of psychotherapy and behavior modification, 2 than from the perspective of helping small groups (families) in the local church.

Other authors have more of a sociological orientation. For example, Urie Bronfenbrenner, in his lead article in a recent book edited by Vaughan and Brazelton, asserts that more working mothers, fewer adults in the home, more single-parent families, and more children of unwed mothers are some of the major problems facing Anerican families today. Because of these and other related factors in family disorganization, one sees change in American children that is building roots of alienation. The demands of the labor market, the popularity of day-care centers, the impact of television, and the nonavailability of parents to their

${ }^{1}$ Koller, Families, A Multigenerational Approach, p. 2. ${ }^{2}$ see Erickson and.Hogan, Family Therapy. 
children are creating an impact of weakness in American families.

Says Bronfenbrenner: "The Future belongs to those nations that are prepared to make and fulfill a primary commitment to their families and to their children."1

Bronfenbrenner urges Americans to be reawakened to a concern for fundamental values.

- among them [values] none should be more dear than a renewed commitment to the nation's children and their families. . in the demanding and richly gratifying task of enabling the young to develop into competent and compassionate human beings. ${ }^{2}$

Other contributors in the same source wrote of

parental deprivation in both dual-parent and single-parent

families as an important problem to overcome. Another problem identified was how to define families in the light of current trends of immorality: ". . . we now define families as at least 1 adult and 1 child, acknowledging the separation of marriage from childbearing." 3

The book ends on a positive note, however.

In answer to the question "can the family be saved?" my answer would be undoubtedly, yes, if we have the courage and the drive to tackle the complex organizations that we live in and make them work for us. 4 .

In spite of the many forces and influences in modern society that threaten the family, this report takes the

${ }^{1}$ Victor C. Vaughan, III, and T. Berry Brazelton, eds., The Family--Can It Be Saved?. (Chicago: Year Book Medical Pub., 1976), P. 32.

$$
{ }^{2} \text { Ibid. } \quad{ }^{3} \text { Ibid., p. } 235 . \quad{ }^{4} \text { Ibid., p. } 306 .
$$


position that it is possible for family members to grow closer together in establishing a happy home. The following quotation undergirds this view.

Home should be made all that the word implies. It should be a little heaven upon earth, a place where the affections are cultivated instead of being studiously repressed. Our happiness depends upon this cultivation of love, sympathy, and true courtesy to one another.1

For a family to grow toward this ideal for the home will require careful communication. This topic will therefore be explored briefly as a part of the field of family enrichment.

\section{Communication}

The importance of communcation between marriage partners and between parents and children is emphasized by one author:

Talk is absolutely essential in marriage. It's married strangers who quarrel most readily. Silence may be golden--sometimes. But silence can also kill. Buttoned-up lips too often indicate an unsteady heart. Without verbal spillways the tension inside becomes too great, and tragedy can result. The very first barrier to communication should be a danger signal. ${ }^{2}$

Yes, youth want help. They want guidance. They want restriction. They want love that cares enough to set some rules. They want consistent example. But too often these are lacking. In a shocking number of cases there is no real communication between parents and youth. 3

${ }^{1}$ Ellen G. White, The Adventist Home (Nashville, Tenn.: Southern Pub. Assn., 1952), p. 15. For additional quotations from Ellen white on the importance of the home, see appendix D.

${ }^{2}$ George E. Vandeman, Happiness Wall to Wall (Mountain View, Calif.: Pacific Press Pub.Assn., 1968), p. 46.

${ }^{3}$ Ibid., p: 60 
Since families are smaller and more isolated today

than they were formerly, family members look more to each other within the family unit to meet their emotional needs. One pastor identifies the four most basic emotional needs that the family ought to meet for its members.

Every person needs an intimate response. This involves tenderness, sensitivity, and appreciation of the special nature of one's personhood. . . .

- . Second, there is the need for adventure. No 1 ife is emotionally whole without a sense of expectancy. . :

- . Our third basic need is for security. . . If your emotional need for security is not being met by persons, you will inevitably seek it in becoming attached to material objects. . .

- . The final basic need $I$ want to mention is recognition. You and I need to be singled out as special. 1

With regard to building effective parent-child reIationships, Huffman asks four questions: 1) "Do I care enough to make any sacrifice for my children?" 2) "Do I take my child seriously as a person?" 3) "Do I respect the privacy of my children's personhood?" and 4) "Do I love my child enough to provide firm discipline?" 2

Koller reports a formula for teenagers to use in getting along with their parents.

With tongue in cheek, one anonymous writer has suggested the following: Suggestions to teenagers on How to Get Along with Their Parents.

Don't be afraid to speak their language. Try using strange-sounding phrases like "I'11 help you wash the dishes" and "yes."

${ }^{1}$ John A. Huffman, Jr., Becoming A Whole Family (Waco, Tex.: Word Books, Pub., 1975), pp.66-72, passim.

2Ibid., pp. 85-96, passim. 
Try to understand theirmusic. Play Glenn Mil1er's "Moonlight Serenade" on the stereo until you become accustomed to the sound.

Be patient with the underachiever. When you catch your dieting Mom sneaking salted nuts, don't show your disapproval. Tell her you like fat mothers.

"Encourage" them to talk about their problems.

Try to keep in mind that to them, things like

earning a living and paying off the mortgage seem important.

Be tolerant of their appearance. When your Dad gets a haircut, don't feel personaly humiliated. Remember its important to him to look like his peers.

And most vital of all: If they do something you consider wrong, let them know it's their behayior you dislike, not themselves.

Remember, parents need to feel they're loved: 1

Another aspect of family enrichment has to do with

recreation. Marion Jacobsen suggests that

Families need a strong, happy sense of togetherness, and most parents want to help create it. But a family's actual experience of being together often proves to be uncomfortable if not painful. Personalities clash and interests conflict. . .

- . This book is about what parents can do to make family living fun--a happy, treasured experience that will reinforce and enrich family relationships for all the coming years. 2

After many practical suggestions on family fun ideas at home and away from home, Jacobsen concludes her book with this good counsel: "Whatever else you do or don't do, enjoy the family God has given you while you have them." 3

It is refreshing for a pastor to read books by other

$1_{\text {Koller, p. } 222 .}$

2 Marion Leach Jacobsen, How To Keep Your Family Together and Still Have Fun (Grand Rapids, Mich.: Zondervan Pub. House, 1973), p. 7 .

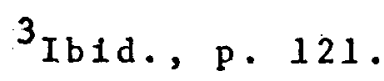


pastors on family life that emphasize God's interest in

families. Larry Christenson has authored such a book.

Most books on family life start with man, then try to include God as a helpful additive. A kind of celestial STP, guaranteed to pep up sluggish family life.

This book comes at it the other way around. The family belongs to God. He created it. He determined its inner structure. He appointed for it its purpose and goal. By divine permission, a man and a woman may cooperate with God's purpose and become a part of it. But the home they establish remains His establishment. 1

\section{- . the secret of good family life is simply}

this: To cultivate the family's relationship with

Russell Becker, a pastor who writes about helping

families in the church, sees the solution for pastoral care as residing not in the pastoral staff alone but in a mutual ministry among the laity to one another, guided by the pastoral staff.

This solution is necessary, Becker believes, because the normative pattern of family life in America is "the isolated conjugal family in a highly mobile society." 3 The circle of caring for others is thus drawn very small and all emotional needs and intimate caring must be provided by a very few others.

Therefore, an ongoing couples Christian concern

${ }^{1}$ Larry Christenson, The Christian Family (Minneapolis, Minn.: Bethany Fellowship, 1970), p. 21 .

2 Ibid., p. 144 .

${ }^{3}$ Russell J. Becker, Family Pastoral Care. (Englewood Cliffs, N.J.: Prentice-Hall, 1965), p. 21. 
group was formed as a. . ministry of the laymen to each other in mutual caring and burden bear-

ing. . . It is a natural constitution of the life of the congregation through which contemporary parents may minister to each other as parents. 1

Becker's couples Christian Concern Group has as its

goal to be more than a self-serving introverted nurture

group. It also wanted to embrace the concept of outward

directed mission. The solution they arrived at was to

consider the family members who worked outside the home as

the missionaries. from the nurture group who went out into

the world. Says Becker:

At one and the same time the couples christian Concern Group addresses itself to the crisis of purpose in the contemporary family and culture and the crisis of introversion and organizational selfserving which afflicts the churches. It is the family which sends a missioner to the world each day in the person. of its breadwinner. 2

In this way, the church members become the new.extended family. The size of the group is ideally kept to six couples although it may vary from five to seven couples, and they found that "one meeting every other week was a frequency that could be sustained on a long-term basis." 3

In addition to the books surveyed in preparation for this project, the writer also attended several seminars on various aspects of marriage, family life, child-training, and human relations, ${ }^{4}$ listened to tape recordings by family

$$
{ }^{1} \text { Ibid. } \quad{ }^{2} \text { Ibid., p. 31. } \quad 3 \text { Ibid., p. } 47 .
$$

${ }^{4}$ Institute in Basic Youth Conflicts, by Bill Gothard, Basic Seminar, Long Beach, Calif., 1971, and the Advanced and Pastor's Seminars, U.C.L.A., 1973; ACME Marriage Enrichment Seminar, Andrews Univers1ty, 1973; Human Relations 
Iife educators, ${ }^{1}$ and surveyed one syllabus, ${ }^{2}$ one doctoral dissertation, ${ }^{3}$ and two doctoral project reports ${ }^{4}$ that related to his report in some way. In addition, several other doctoral dissertations have been discovered which other students of family-life education may wish to consult. 5

Workshop, by Dr. C. C. Crider, Andrews University, 1974; Marriage Enrichment Seminar, by Dr. Edward C. Banks, Andrews University, 1974; Family Leadership Seminar, by Drs. John and Millie Youngberg, along the banks of the Pere Marquette River, Michigan, 1974; and a Camp Au Sable Retreat, Family Seminar, by Drs. John and Millie Youngberg, Michigan, 1974 .

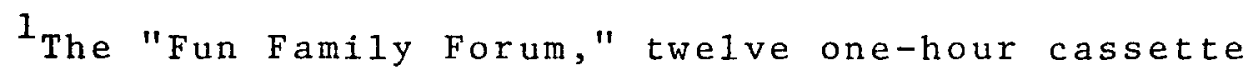
tapes, by Charlie Shedd, available from Creative Resources, A Division of Word, 4800 West Waco Dr., Waco, TE 76703; and the "Happy Christian Home," six one-hour cassette tapes by Tim La Haye, Family Life Seminars, P.0. Box 1299, E1 Cajon, CA 92022 .

2 syllabus for "Together Again" seminar on Marriage by Shirley Macaulay, 6659 Sunset Circle, Riverside, CA 92505 .

3 John B. Youngberg, "A Study of Leadership Concepts and their Application in Family-life Education Training Courses in a Seventh-day Adventist Community" (Ed.D. dissertation, Western Michigan University, 1974).

${ }^{4}$ Elwood E. Staff, "An Inquiry into the Needs and Problems of the Seventh-day Adventist One-Parent Family" (D.Min. Project Report, Andrews University, 1974); Gordon G. Bietz, "The Development and Formative Evaluation of Instructional Materials and Procedures Designed to Teach the Concept of Christian Witness" (D.Min. Project Report, Andrews University, 1976).

5 Ross Thomas Bender, "The Role of the Contemporary Family in Christian Nurture: A Theological Interpretation" (Ph.D. dissertation, Yale University, 1962); Samue1 H. Cox, "Family Background Effects on Personality Development and Social Acceptance" (Ph.D. dissertation, Texas Christian University, 1966); John Frances Doherty, "A Study of Change in the Religious and Social Attitudes of 85 Members of the Christian Family Action Movement in a Suburban Parish" (Ph.D. dissertation, Fordham University, 1963); Jean Bonner Howell, "A Family Ministry Approach to Christian Education for 
From the preceding pages, which have surveyed the literature of family enrichment, several conclusions may be drawn: (1) premarital preparation is advisable, (2) good marriages can be improved, (3) relationship crises oftén require counseling, (4) proper child training is very important, (5) a smali group ministry can benefit Christian families, and (6) family relationships can be improved. In addition, two trends have been observed in the currently available literature. Firstly, most of the available information on family life is compartmentalized to deal separately with husband-wife or parent-child relationships. Very few works discuss the whole family together. Secondly, most works view these relationship problems as human interactions without much influence from God in the development of love for one another in families.

Studying family dynamics compartmentally and focusing on them outside the context of God's influences in building love in families are seen by this writer as

Southern Baptist Churches" (D.R.E., the Southern Baptist Theological Seminary, 1967); Margaret R. Owen, "A Philosophy for Christian Family Life" (Ph.D. dissertation, Columbia University, 1952); Arthur James Powel1, "The Influence of Family Life in the Development of Christian Personal Morality" (Ph.D. dissertation, Southern Baptist Theological Seminary, 1963); Lawrence 0. Richards, "Pre-evaluative Research on a Church/Home Christian Education Program" (Ph.D. dissertation, Northwestern University, 1972); Ernest Stricklin, "Christian Family Life Education Implied in the Covenant Life Curriculum of the Presbyterian Church in the United States" (Th.D. dissertation, Boston University School of Theology, 1964). 
limitations in the avallable literature in the field of family enrichment.

An attempt has therefore been made, in this project, to develop a family spiritual enrichment seminar that will eliminate these two weaknesses.

\section{Some Distinctive Features of Home, the School of Love}

Since the family-life seminars of which this writer is aware seem to follow one of three patterns, namely, (1) they are usually limited to one phase of familylife education, such as: (a) marriage enrichment or (b) parent-child relationships; ${ }^{1}$ (2) they are often strong1y teacher/leader centered rather than group centered; or (3) their goals are task oriented toward a different goal from the development of love, such as clarifying roles in family-leadership patterns; a need was perceived for a different approach.

The present seminar is therefore distinctive because it (1) includes elements that address themselves to developing love in divine-human relationships, marriage relationships, parent-child relationships, and sibling relationships; (2) it is centered partly in the small-group interaction process and party in the seminar leader, rather than so exclusively centered in the seminar leader;

${ }^{1}$ An exception to this rule is Youngberg, who includes family members of all ages and in their varying relationships to each other within the family. 
and (3) its task orientation lies in helping families learn how to develop love at home for God, each other, and for those outside the family. 
CHAPTER III

HOME, THE SCHOOL OF LOVE

\section{Introduction}

This chapter presents a context for "Home, the

School of Love: A Seminar in Family Spiritual Enrichment." While the concept of the home is a very important part of this seminar, it is not the central issue. Love is the central issue, with the home as an important environment for nuturing the development of love for God and man. Therefore this chapter presents a context for love as we11 as for the family.

For convenience, the subject is divided into three parts. In part one, love as a part of the image of God in man is discussed. In the second section, the loss and the restoration of love as part of the image of God in man is given consideration. Thirdly, the importance of the home as a place for the development of love will be investigated.

Love as a Part of the Image of God in Man

Moses declares that "God created man in his own image."1 The Apostle John asserts that "God is love." 2

$$
\begin{aligned}
& { }^{1} \text { Gen } 1: 27 \\
& 21 \text { Ji } 4: 8
\end{aligned}
$$


While there is no statement in either the 01d or New Testaments that explicitly connects these two ideas, one could deduce that when these two biblical statements are taken together love is a part of the image of God in man. To explore this hypothesis further will be the task of the next few pages.

The image of God in man is first mentioned in the scriptures in Gen 1:26, 27.

And God said, Let us make man in our image after our likeness: and let them have dominion over the fish of the sea, and over the fowl of the air, and over the cattle, and over all the earth, and over every creeping thing that creepeth upon the earth. So God created man in his own image, in the image of God created he him; male and female created he them. (Italics mine.)

To understand the nature of man at his creation requires a look into the meaning of the Hebrew words which are translated here as "image" and "likeness." The English word "image" is translated from the Hebrew word tselem, 1 This Hebrew word is translated once as "form" and sixteen times as "image." 2

A second passage in Genesis where tselem is translated "image" with reference to man's original creation is found in Gen 9:6: "Whoso sheddeth man's blood, by man shall. his blood be shed: for in the image of God made he man."

${ }^{1}$ Robert Young, Analytical Concordance to the Bible, (Grand Rapids, Mich.: Wm. B. Eerdmans Publishing Company, $22 \mathrm{~d}$ American Edition), p. 509. p. 51 .

2Ibid., "Index-Lexicon to the old Testament," 
Both the Gen 1:26, 27 and the Gen 9:6 passages proclaim the exalted position of man because of the honor bestowed upon him by God at creation in making man in His own image. There is a third passage, however, in which tselem does not refer to such a divine-human comparison. This third passage is Gen 5:3. "And Adam lived an hundred and thirty years, and begat a son in his own likeness, after his image; and called his name Seth." Tselem is used here to describe a human to human comparison which is different from the previously mentioned divine-human comparisons.

In this last reference, the world "1ikeness" is also used, as it was in Gen 1:26. The Hebrew word translated in these two places as "likeness" is demuth. 1 This word is translated once each as "fashion," "manner," "1ike as," twice as "similitude," and nineteen times as "1ikeness." 2

The word "likeness" is also used in Gen $5: 1,2$.

This is the book of the generations of Adam. In the day that God created man, in the likeness of God made he him; male and female created he them; and blessed them, and called their name Adam, in the day when they were created.

It can be seen from these verses that the same two Hebrew words, tselem and demuth, are used to describe the similarity of relationship between God and man as are used to describe the similarity of relationship between Adam and

${ }^{1}$ Young, p. 608.

${ }^{2}$ Ibid., "Index-Lexicon to the old Testament, p. 14. 
Seth. One must be careful, however, not to stretch these similarities too far. Whereas Adam and Eve were related to God by creation, they were related to seth by procreation-and there is as vast a difference between these two methods of generation as there is between divine beings and human beings .

While believing that man is a whole person, ${ }^{1}$ he can still be discussed compartmentally. Therefore four suggested ways in which Adam was like God can be stated briefly as socially, menta11y, spiritual1y, and physica11y.

Socially, Adam and Eve were created to be together, to love each other, to live in harmony with one another in a satisfying and close personal relationship. The fact that God is not alone but exists as three persons comprising the one triune Godhead suggests the sociability of the Creator. It also provides a strong suggestion of God as one who 1oves.

Menta11y, Adam and Eve were capable of engaging in a meaningful relationship with each other and with God. They were also entrusted by God with the responsibility of having dominion over the flora and fauna of the world, which would have required the exercise of intelligence and wisdom.

${ }^{1}$ For a discussion of the scriptural emphasis of man as a whole person and not as a dualistic or pluralistic being, see G. C. Berkouwer, Man: The Image of God (Grand Rapids, Mich.: Wm. B. Eerdmans Pub. Co., 1962), pp. 77, 203 ; and Sherrill, pp. 190-91. 
Spiritually, man was created with the capacity for knowing, understanding, and worshipping his creator. This capacity for expressing love and adoration for divine beings and to exercise decision-making abilities on the moral level in distinguishing right from wrong, such as at the tree of knowledge of good and evil, also set man apart from the rest of the creatures of earth.

It is suggested by some that man also bore a physical resemblance to God.

Created to be "the image and glory of God" ( 1 Corinthians 11:7), Adam and Eve had received endowments not unworthy of their high destiny. Graceful and symmetrical in form, regular and beautiful in feature, their countenances glowing with the tint of health and the light of joy and hope, they bore in outward resemblance the likeness of their Maker. Nor was this likeness manifest in the physical nature only. Every faculty of mind and soul reflected the Creator's glory.1

While the similarities between God and man have been described in this section under four separate headings, man is none the less to be regarded as a holistic being. Greek philosophers have suggested a dichotomy in human nature as both body and soul, while Hebrew thinkers saw man as a unity.2 It is from the latter source of antiquity that Christianity has a greater affinity.

$$
\frac{\text { The Loss and Restoration of Love as a Part }}{\text { of the Image of God in Man }}
$$

Biblical revelation has informed us that man fell from his high position of likeness to God when he disobeyed 
God and committed sin. ${ }^{1}$ God had forbidden Adam and Eve to eat of the fruit of the tree of knowledge of good and evil. The consequence of disobeying this prohibition was separation from God, Who is the source of life. The natural result of separation from God was a diminishing of every aspect of the image of God in man.

The Scriptures plainly declare both modern man's inheritance of the death penalty through the transgression of man's first parents and the possiblity of the restoration of life through Christ. "For as in Adam all die, even so in Christ shall all be made alive." 2

The extent to which man has lost (by his fall into sin) the image of God in which he was originally created is appalling. The first hint of what man had lost is given in Gen 3:7-24. Some of these losses here indicated include an awareness of their nakedness followed by shame; fear of God; blaming each other; the cursing of the serpent; the promise of the Savior's future death; the husband to "rule over" the wife; cursing the ground; eventaully returning to dust; animals dying so "coats of skins" could be made for clothing; and losing his beautiful garden home. The depravity of sinful man is described further in Rom 1:18-32, where three times God is said to have given men "up" or given them "over" to their "uncleanness," their "vile

${ }^{1}$ See Gen 3:1-19 for a description of the Fal1.

21 cor 15:22. 
affections," and "to a reprobate mind," because they were

"filled with all unrighteousness." This great loss is portrayed still further in the following quotation.

Through sin the divine likeness [in man] was marred, and well-nigh obliterated. Man's physical powers were weakened, his mental capacity was lessened, his spiritual vision dimmed.

Since the whole image of God in man was marred by sin, and since the capacity to love is understood to be one feature of the image of God in man, it follows that man's capacity to love was also seriously impaired. Any attempt to restore the image of God in man must also include the restoration of man as a lover of God and man. Since man's fall in Eden, it has ever been God's plan for a complete restoration in man of the image of God. This restoration is the great objective of the plan of redemption.

To restore in man the image of his Maker, to bring him back to the perfection in which he was created, to promote the development of body, mind, and soul, that the divine purpose in his creation might be realized--this was to be the work of redemption. This is the object of education, the great object of life. 2

The importance of this restoration is emphasized in

the following quotation:

Though the moral image of God was almost obliterated by the sin of Adam, through the merits and powers of Jesus it may be renewed. Man may stand with the moral image of God in his character; for. Jesus will give it to him. Unless the moral image of God is seen in man, he can never enter the

$1_{\text {White, Education, }}$ p. 15. 2Ibid. 
city of God as a conqueror. 1

This restoration of God's image in man is not to be accomplished by man's own works of righteousness. Instead this transformation of character results from an experience of righteousness by faith in Jesus Christ.

The above quotation stated clearly that this change takes place "through the merits and powers of Jesus" and that "Jesus will give it [the moral image of God] to him [man]." (Italics mine.) It is true therefore that, "None but christ can fashion anew the character that has been ruined by sin." 2

In the beginning, man was created in the likeness of God, not only in character, but in form and feature. Sin defaced and almost obliterated the divine image, but christ came to restore that which had been lost. He will change our vile bodies and fashion them like unto His glorious body. . . The last lingering traces of sin will be removed, and Christ's faithful ones will appear in "the beauty of the Lord our God," in mind and soul and body reflecting the perfect image of their.Lord. 3

It is evident from these statements that the restoration of the image of God in man will include a complete restoration of the physical, mental, spiritual, and social

${ }^{1}$ E11en G. White, Review and Herald, June 10, 1890, as quoted in Francis D. Nichol, ed. The Seventh-day Adventist Bible Commentary, 7 vols. (Washington, D.C.: Review and Herald Pub. Assn., 1957), 6:1078.

${ }^{2}$ White, Desire of Ages, p. 38 .

${ }^{3}$ Ellen G. White, The Great Controversy (Mountain View, Calif.: Pacific Press Pub. Assn., 1950), pp. 644-45. 
powers to their original purity.l This holistic restoration embodies character development in all of its aspects, including man's capacity for giving and receiving love. This character development is precisely what God is waiting for in order to return to earth again.

Christ is waiting with longing desire for the manifestation of Himself in His church. When the character of Christ shall be perfectly reproduced in His people, then He will come to claim them as His own.

It is the privilege of every Christian not only to look for but to hasten the coming of our Lord Jesus Christ (2 Peter 3:12 margin). 2

The centrality of love in character development as it relates to the restoration of the image of God in man is indicated by the nature of God.

"He that loveth not, knoweth not God; for God is love." 3 Since God is love, and since man was created in God's image, the restoration of the image of God in man must also include the restoration in man of love--love for God and love for man. The importance of love for God can be seen in the following quotation:

Love, the basis of creation and of redemption, is the basis of true education. This is made plain in the law that God has given as the guide of life. The first and great commandment is "Thou shalt love the Lord thy God with all thy heart, and with all thy soul, and with all thy strength, and with all thy mind." Luke 10:27. To love Him, the infinite,

${ }^{1}$ For additional Ellen $G$. White quotations on the restoration of the image of God in man, see appendix A.

${ }^{2}$ Ellen G. White, Christ's Object Lessons (Washington, D.C.: Review and Herald Pub. Assn., 1941), p. 69.

31 Jn $4: 8$. 
the omniscient one, with the whole strength, and mind, and heart means the highest development of every power. It means that in the whole being--the body, the mind, as well as the soul-the image of God is to be restored. 1

The importance of love for man, can also be seen in

this same work.

Like the first is the second commandment-"Thou shalt love thy neighbor as thyself."

Matthew 22:39. The law of love calls for the devotion of body, mind, and soul to the service of God and our fellow men. And this service, while making us a blessing to others, brings the greatest blessing to ourselves. Unselfishness underlies all true development. Through unselfish service we receive the highest culture of every faculty. More and more fully do we become partakers of the divine nature. We are fitted for heaven, for we receive heaven into our hearts. 2

This same author identifies the connection between

love and the purpose of the incarnation of Christ in the

fol1owing words:

It is the gospel of the grace of God alone that can uplift the soul. The contemplation of the love of God manifested in His son will stir the heart and arouse the powers of the soul as nothing else can. Christ came that He might recreate the image of God in man; and whoever turns men away from christ is turning them away from the source. of true development; he is defrauding them of the hope and purpose and glory of life. (Italics mine.) ${ }^{3}$

Another statement from this same author equates

God's character with love." . . the character of God,

whose likeness we are to receive, is benevolence and love." 4

${ }^{1}$ White, Education, p. $16 . \quad 2$ Ibid.

${ }^{3}$ White, Desire of Ages, p. 478 .

${ }^{4}$ Ellen G. White, Patriarchs and Prophets (Mountain

View, Calif.: Pacific Press Pub. Assn., 1913), p. 595. 
Another author who identifies love as the essential primary element in the image of God is G. C. Berkouwer.1 To clarify the relationship between love and law, Ellen White states that:

Christ came to the world, with the accumulated love of eternity. Sweeping away the exactions which had encumbered the law of God, He showed that the law is a law of love, an expression of Divine Goodness. He showed that in obedience to its principles is involved the happiness of mankind, and with it the stability, the very foundation and framework, of human society. ${ }^{2}$

Thus one can see that love is a vital ingredient, if not the central quality, in the restoration of the image of God in man. Even the biblical concept of the remnant people who "keep the commandments of God"3 encompasses the principle of love--"For this is the love of God, that we keep his commandments."4 "Love is the fulfilling of the law."5 "If we love one another, God dwelleth in us, and his love is perfected in us."6 "Only the service of love can be acceptable to God." 7

There is nothing that Christ desires so much as agents who will represent to the world His spirit and character. There is nothing that the world needs so much, as the manifestation through humanity of the Saviour's love. All heaven is waiting for channels through which can be poured the holy oil to be a joy and blessing to human hearts. 8

$1_{\text {Berkouwer; pp. } 49,60 .}$

${ }^{2}$ White, Education, p. $76 . \quad 3_{\text {Rev }} 12: 17$.

${ }^{4} 1$ Jn $5: 3 . \quad{ }^{5}$ Rom $13: 10.6{ }_{1}$ Jn $4: 12$.

7 White, patriarchs and prophets, p. 42.

${ }^{8}$ White, Christ's Object Lessons, p. 419. 
Therefore, love for God and man in the life of the Christian is the goal to be sought, the experience to be desired, and the highest form of motivation in character development. When genuine love for God and man are present in the life of a Christian, he will live a life characterized by obedience to God and helpfulness toward people. To assist people in experiencing deepening love relationships with God and man is therefore the primary goal of the seminar project reported in this paper.

It is recognized, however, that much more time will be spent by the participants outside the seminar than in one. Some degree of love is already developed, or underdeveloped, in every home before the participants come to the seminar. Likewise, the development of love will continue to be a life-long process after the seminar is over. 1 Because of this, the home needs to be recognized as the place where love is really going to be developed with continuity.

It needs to be emphasized at this point that the meaning of the word love is explored, and hopefully clarified, in chapter I of this report. To understand the development of love in the home, the reader should familiarize himself with the material on love in chapter I. It will be stated here briefly, however, that love is a word that describes a whole range of personal, human experiences.

IFor additional quotations on love by E1len White, see appendix $B$. 
It is not just an isolated, abstract idea. Yet it cannot be completely understood in sociological terms. The meaning of love for the Christian is rooted in its theologica 1 , Judeo-Christian undergirding as found in both the old and New Testaments.

Love is understood best when one sees it in the context of God's love for man and in its relationship to the home. Perhaps this is why the biblical description of love so often involves the home. For example, God's love in the 01d Testament is variously compared to a father's love for his child (Hos 11:8), a mother's love for her child (Is 49: 15), a husband's love for his harlot wife (Hos 1:2ff), and His covenant love for His chósen people (Dt 7:6-9). In addition, God's people are commanded in the New Testament to love their enemies (Mt 5:44), to love their neighbor as themselves (M.t. 22:39), and to love each other as Jesus has loved them (Jn 13:34). While husbands are urged to love their wives as themselves (Eph 5:33), as Christ loved the church and gave Himself for it (Eph 5:25), wives are urged to reverence their husbands (Eph 5:33). These comparisons of the love experience are al1 set in the framework of human interpersonal relationships, either among family members within the home or as family members relate to people outside their homes. It is suggested in this study, therefore, that the home is the crucial place for the development of love. 
The Home as a School for the Development of Love

It is in the home that the early lessons of child-

hood are learned. The home is therefore the child's first school.1. The Christian family is to be a training school from which children are to graduate to a higher school in the mansions of God.2

It is in the home that the education of the child is to begin. Here is his first school. Here, with his parents as instructors, he is to learn the lessons that are to guide him throughout life-lessons of respect, obedience, reverence, selfcontrol. The educational influences of the home are a decided power for good or for evil. They are in many respects silent and gradual, but if exerted on the right side, they become a far-reaching power for truth and righteousness. If the child is not instructed aright here, Satan will educate him through agencies of his choosing. How important then, is the school in the home. 3

Jesus secured His education in the home. His mother was His first human teacher. From her lips, and from the scrolls of the prophets, He learned of heavenly things. He lived in a peasant's home and faithfully and cheerfully acted His part in bearing the household burdens. He who had been the commander of heaven was a willing servant, a loving, obedient son. He learned a trade, and with His own hands worked in the carpenter's shop with Joseph.4

Too much importance cannot be placed on the early training of children. The lessons that the child learns during the first seven years. of life have more to do with forming his character than all that it learns in future years. 5

${ }^{1}$ Ellen G. White, Child Guidance (Nashville, Tenn.: Southern Pub. Assn., 1954), p. 17 .

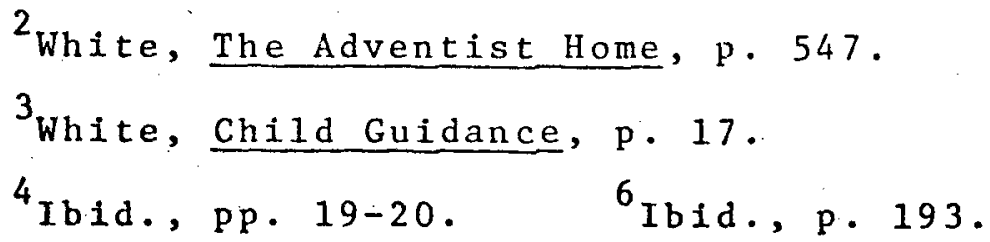


One pair of authors suggests that most children would do best in school if they were to stay in their homes and be cared for by their own parents until they reach their Integrated Maturity Level (I.M.L.), which is not usually reached until the child is from eight to ten years old. 1 Erik H. Erikson, who is credited by one writer ${ }^{2}$ as having blazed the trail in the developmental psychology of religion and having made his great contribution by hypothesizing "an eight-stage series of life crises that includes what happens to people from birth to death," 3 suggests that:

The most fundamental prerequisite of mental vitality - . is a sense of basictrust, which is a pervasive attitude toward oneself and the world derived from the experiences of the first year of life. By "trust" I mean an essential trustfulness of others as well as a fundamental sense of one's own trustworthiness. 4

If the parental home were a place where the preschool child would learn the first lessons of basis trust, would he not be off to the best possible start in his young life? The biblical record reveals that the home can be a

${ }^{1}$ For details on this concept see Raymond $S$. Moore and Dorothy $N$. Moore, Better Late Than Early: A New Approach to Your Child's Education (New York: Reader's Digest Press, dist. by E. P. Dutton \& Co., 1975).

${ }^{2}$ See John J. Gleason, Jr., Growing Up to God: Eight Steps in Religious Development (Nashville, Tenn.: Abingdon Press, 1975).

3 Ibid., p. 17 .

${ }^{4}$ Erik H. Erikson, Identity: Youth and Crisis

(New York: W. W. Norton \& Co., 1968), p.96. 
successul nurture center. It was for Moses (Ex 2:1ff),

for Samue1. ( 1 Sam 1:19ff), for Jesus (Mt 1:23ff; 2:11ff;

Lk 1:40ff; etc.), and for Timothy (2 Tim 1:5;3:14, 15),

One author observes that Timothy "learned the

Scriptures we 11 from mother and grandmother. It is clear

that [for Timothy] nurture was a family affair. And it still is." 1

The same author suggests that,

While all Christian education is not to take place in the home, a "iamily relationship" or "family feeling" is to be of concern in every teaching/learning setting. Rather than abandoning the home as the nurture center for children in favor of an imitation of school, we are to reaffirm the centrality of the home, and take seriously our task of devising educational systems which will support parents in that task. ${ }^{2}$

While parents "still are the primary socialization agents for young children," 3 not a 11 of a child's religious education takes place in his home or by the members of his family

- . friends, teachers, parents, and God can establish a quality of relationship that enhances feelings of esteem, changes the way of perceiving the self, and helps young people to believe in their worth and significance: 4

Regarding the influence of a parochial school in addition to the home, one author states:

${ }^{1}$ Lawrence 0 . Richards, A Theology Christian Education (Grand Rapids, Mich.: Zondervan Publishing House, 1975), p. 195 .

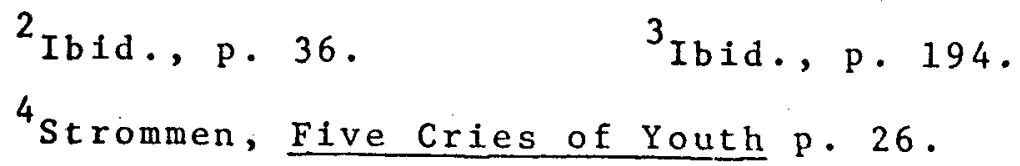


The relevant empirical research suggests that superior religious learning in school-age children tends to be produced by a simultaneous combination of church-sponsored school and religiously-oriented nonschool (for example, family) learning environments, as contrasted to the level and quality of religious learning produced by either the churchsponsored school or the religiously-oriented nonschool environments taken alone.

He also points out that religious instruction is not limited to the family or the school but.it takes place in the child's little society, "be that society the family, the school, the formal religion class, or an informal peer-group association." 2

Regarding a weakness in research on religious education (wherever it takes place), strommen notes that:

- . most of the published research in religion is cross-sectional rather than longitudinal in time. There are precious few studies which enable one to trace religious development over a period of time. ${ }^{3}$

Some of the parents in America provide little or no positive religious education for their children. The atheistic or agnostic families may not be interested in providing religious instruction, while some religiously oriented families do not believe they are adequately trained to do so. By way of contrast, Adventist families generally desire to

${ }^{1}$ James Michael Lee, The Shape of Religious Instruction (Mishawaka, Ind.: Religious Education Press, 1971), p. 7 .

2 Ibid., p. 27

${ }^{3}$ Merton Strommen, ed., Research on Religious Development: A Comprehensive Handbook (New York: Hawthorn Books, 1971), p. xiv. 
provide for their children's religious instruction while

they are at home, school, church, and elsewhere. In common with other families in America, they vary in their ability to fulfill this desire, and, in some cases, they do not adequately perceive their deficiencies in parent-child relationships.1 The church has the opportunity and the responsibility to help parents provide for their children's religious training. This is most effectively accomplished when there is a consistency between the two.

- All the Sunday school lessons, all the catechism classes which emphasize that God is love, that God is forgiving, and that there is such a thing in the Christian faith as redemption may fall on deaf ears if a child has at home experienced from his first gods [his parents] the feeling lessons that he or she is worthless. . . .2

As parents are helped to love each other, to establish a climate of trust, and to begin communicating with their teenage children a revolution ensues in the home. At least half the parents of church youth would profit from education to bring about such changes. 3

Another positive influence of which Christian families can avail themselves is the Christian school.

The teachers in Christian schools need to be sanctified through the truth, and the all-important thing should be the conversion of their students, that they may have a new heart and life. The object

${ }^{1}$ When Kenneth Keniston analyzed the families of the "Chicago Seven" criminals, he found that their parents believed they were loving. See Kenneth Keniston, Youth and Dissent: The Rise of a New Opposition (New York: Harcourt Brace Jovanovich, A Harvest Book, 1971).

${ }^{2}$ Gleason, p. 51 .

${ }^{3}$ Strommen, Five Cries of Youth, p. 49. 
of the Great Teacher is the restoration of the image of God in the soul, and every teacher in our schools should work in harmony with this purpose. 1

One of the best biblical statements on the importance of the home as a training center for love is Dt 6:4-8.

Hear, 0 Israel: The Lord our God is one Lord: and thou shalt love the Lord thy God with all thine heart, and with all thy soul, and with all thy might. And these words, which I command thee this day, shall be in thine heart: And thou shalt teach them diligently unto thy children, and shalt talk of them when thou sittest in thine house, and when thou walkest by the way, and when thou liest down, and when thou risest up. And thou shalt bind them for a sign upon thine hand, and they shall be as frontlets between thine eyes.

In commenting on these verses, one author states his

opinion that

- . The critical location for Bible teaching is not the classroom but rather the household. . . It is in life itself, where Bible truths are to have meaning for us as whole persons, that their communication must center.2

To conclude this chapter, the following quotation is offered.

Fathers and mothers should look upon their children as younger members of the Lord's family, committed to them to educate for heaven. The lessons that we ourselves learn from Christ we should give to our children, as the young minds can receive them, little by little opening to them the beauty of the principles of heaven. Thus the Christian home.

${ }^{1}$ Ellen G. White, Fundamentals of Christian.

Education (Nashville, Tenn.: Southern Pub. Assn., 1923), p. 436 .

p. 193 .

${ }^{2}$ Richards, A Theology of Christian Education, 
becomes a school where the parents serve as underteachers, while christ Himself is the chief instructor. 1 (Italics mine.)

$1_{\text {White, The Desire of Ages, p. 515; for additional }}$ quotations on the importance of the home as a training school for love, see appendix $C$. 
CHAPTER IV

THE BENTON HARBOR SEMINAR

\section{Introduction}

This chapter describes the arrangements for, the content of, and the evaluation data reported from the first seminar on "Home, the School of Love." Part one of this chapter will discuss the arrangements for the writer's first seminar; part two will relate the steps involved in conducting the seminar in the Benton Harbor, Michigan, Seventh-day Adventist Church; and part three will report the evaluation data.

\section{Arranging for the Seminar}

Gaining Approval from the Benton Harbor Church.

One of the writer's goals while he was in residence in Michigan as a student at Andrews University was to conduct one seminar in the vicinity of the University. Conversations with $C$. Raymond Holmes, pastor of the Benton Harbor Seventh-day Adventist Church, led to the decision that a seminar on the home would be beneficial to the church and would provide a testing ground for the seminar, "Home, the School of Love."

The city of Benton Harbor is located about thirteen miles north of Berrien Springs. The writer 
subsequently attended a church board meeting at the Benton Harbor Adventist Church and secured its approval to conduct his first family seminar there in the church facility.

\section{Staffing the Seminar}

In staffing the seminar, the writer's intent was to provide more than a "one-man-show." It was his philosophy that every seminar participant would bring to the seminar his own background of experience as a member of his own family of origin. In addition, each participant would bring his experiences with him as a member of his family of procreation. Therefore, in the family seminar, the participants were viewed as a group in which every learner was also a teacher, and every teacher was also a learner. In this way the participants were considered a part of the staff of resource people, sharing insights from their own 1 ives.

Beyond this, a need was perceived to provide child care for the younger family members who would be too immature to be involved in the group process. or to help make the decisions that would be necessary for families to improve their lives together. Therefore, several Andrews. University undergraduate students were contacted and interviewed by Elder. Holmes and the writer together. These students agreed to take care of the children age eight and under.

To provide the primary leadership for the seminar, 
three Doctor of Ministry students were invited to join the writer in planning and conducting the seminar. Andre Stijnman agreed to lead in discussions on family worship, corporate worship, and the influence of television on the family; Desmond Cummings, Jr., planned to direct a section on love discipline; and C. Raymond Holmes was assigned as a group leader and participant because of his already established leadership role as the pastor of the church. In addition, Richard Lange was invited to present the witnessing module during the fifth group session. The writer was the overall leader and was responsible for the remaining subjects of the seminar. To build up a reservoir of confidence and goodwill with the congregation, he and his family attended the Sabbath services of the Benton Harbor Church for a period of about nine months in all, approximately six months before the seminar and three months after the seminar.

During his involvement at the Benton Harbor Church, opportunities were given for the writer to preach several sermons, assist during Sabbath School and worship services, and assist, when needed, in teaching a Sabbath School class. Friendships were developed between the writer's family and some of the other families of the church. These contacts were helpful in introducing the seminar leader to the congregation before the seminar began. 


\section{Conducting the Seminar}

Invitations

Elder Holmes mailed a letter of invitation and an application blank to register for the seminar to all of his church members. The seminar was scheduled to begin in the Benton Harbor Church at 11:00 o'clock on Sabbath morn-

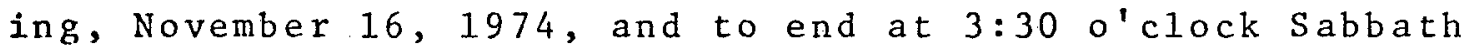
afternoon, Novernber 23, with meetings each evening except Sabbath and Friday. The members were invited to register by November 16 .

Schedule

The schedule of meetings was as follows:

11:00 a.m. Sabbath Nov. 16 Worship Service $1 \mathrm{hr}$. 7-8:30 p.m. Sunday Nov. 17 lst Group Session $1 \frac{1}{2} \mathrm{hrs}$. 7-3:30 p.m. Monday Nov. 18. 2nd Group Session $1 \frac{1}{2}$ hrs. 7-8:30 p.m. Tuesday Nov. 19 3rd Group Session 1 $\frac{1}{2} \mathrm{hrs}$. 7-8:30 p.m. Wednesday Nov. 20. 4th Group Session 1 $\frac{1}{2}$ hrs. 7-8:30 p.m. Thursday Nov. 21 5th Group Session 1 $\frac{1}{2}$ hrs. 11:00 a.m. Sabbath Nov. 23 Worship Service $1 \mathrm{hr}$. $1: 30-3: 30$ p.m. Sabbath Nov. 23 6th Group Session 2 hrs.

Total $11 \frac{1}{2} \mathrm{hrs}$.

Format of the Seminar Meetings

The seminar format that may be helpful in understanding how each session was organized will be presented next in the form of a series of charts.

${ }^{1}$ See appendix E for a sample copy of the letter of invitation and the application blank. 
CHART I

INTRODUCTORY MEETING, SABBATH, NOVEMBER 16, 1974

objective: To introduce the seminar.

\begin{tabular}{|c|c|c|c|c|}
\hline \multicolumn{2}{|c|}{$\begin{array}{l}\text { Instructional } \\
\text { Content }\end{array}$} & \multirow{2}{*}{$\begin{array}{l}\text { Process } \\
\text { Prayer for. God's bless- } \\
\text { Ing and guidance in } \\
\text { worship service as we } \\
\text { focus on the famliy }\end{array}$} & \multirow{2}{*}{$\begin{array}{l}\text { Sources } \\
\text { Personal thought glven } \\
\text { to content of prayer } \\
\text { In advance of service }\end{array}$} & $\begin{array}{l}\text { Schedule of } \\
\text { Time and Place }\end{array}$ \\
\hline & Invocetion & & & $\begin{array}{l}\text { 11:00 a.m., Benton } \\
\text { Harbor Adventist } \\
\text { Church }\end{array}$ \\
\hline & Open1ng hymn & Congregational singing & $\begin{array}{l}\text { Church Hymal, \#145, } \\
\text { "Oh Love That Wilt Not } \\
\text { Let Me Go" }\end{array}$ & $11: 02$ a.m. \\
\hline & $\begin{array}{l}\text { Scripture and } \\
\text { prayer }\end{array}$ & $\begin{array}{l}\text { Read aloud by Andre } \\
\text { Stifnman }\end{array}$ & De $6: 4-7$ & $11: 07 \mathrm{a} . \mathrm{m}$. \\
\hline 4. & $\begin{array}{l}\text { Ch1ldren's } \\
\text { story }\end{array}$ & $\begin{array}{l}\text { Bob Cowan gathered little } \\
\text { children up front and told } \\
\text { story about how hornets } \\
\text { work together to bulld } \\
\text { their home; application to } \\
\text { people }\end{array}$ & $\begin{array}{l}\text { Visual atd of large, } \\
\text { genulne hornets nest } \\
\text { borrowed from nelghbor; } \\
\text { encyclopedia article on } \\
\text { hornets }\end{array}$ & $11: 12$ a.m. \\
\hline 5 . & Sermon & $\begin{array}{l}\text { Bob Cowan preached for } 30 \\
\text { minutes, expository sermon: } \\
\text { Love for cod taught in the } \\
\text { family is the goal of the } \\
\text { Christian and of the semi- } \\
\text { nar }\end{array}$ & $\begin{array}{l}\text { Preaching portion: } \\
\text { Dt } 6: 4-7 \\
\text { See Appendtx E for } \\
\text { sermon outline }\end{array}$ & $11: 30 \mathrm{a} \cdot \mathrm{m}$. \\
\hline & Closing hymn & Congregational singing & $\begin{array}{l}\text { Church Hymnal, \#343, } \\
\text { "I Love Thee" }\end{array}$ & $12: 00$ noon \\
\hline & Benediction & Local Elder leads out & $\begin{array}{l}\text { Prayer of enablement to } \\
\text { accomplish goals pre- } \\
\text { sented }\end{array}$ & $12: 05 \mathrm{p} . \mathrm{m}$. \\
\hline
\end{tabular}




\section{CHART II}

FIRST GROUP SESSION, SUNDAY, NOVEMBER 17,1974

\section{object1ves:}

1. To promote an atmosphere of warmth, friendliness, and welcome for partic1pants.

2. To gather information from particlpants about their degree of love for God,

family, and others at beginning of seminar via Family survey.

3. To explain what will be happening in the seminar during the week.

4. To present the fundamental goals of developing love for God and man.

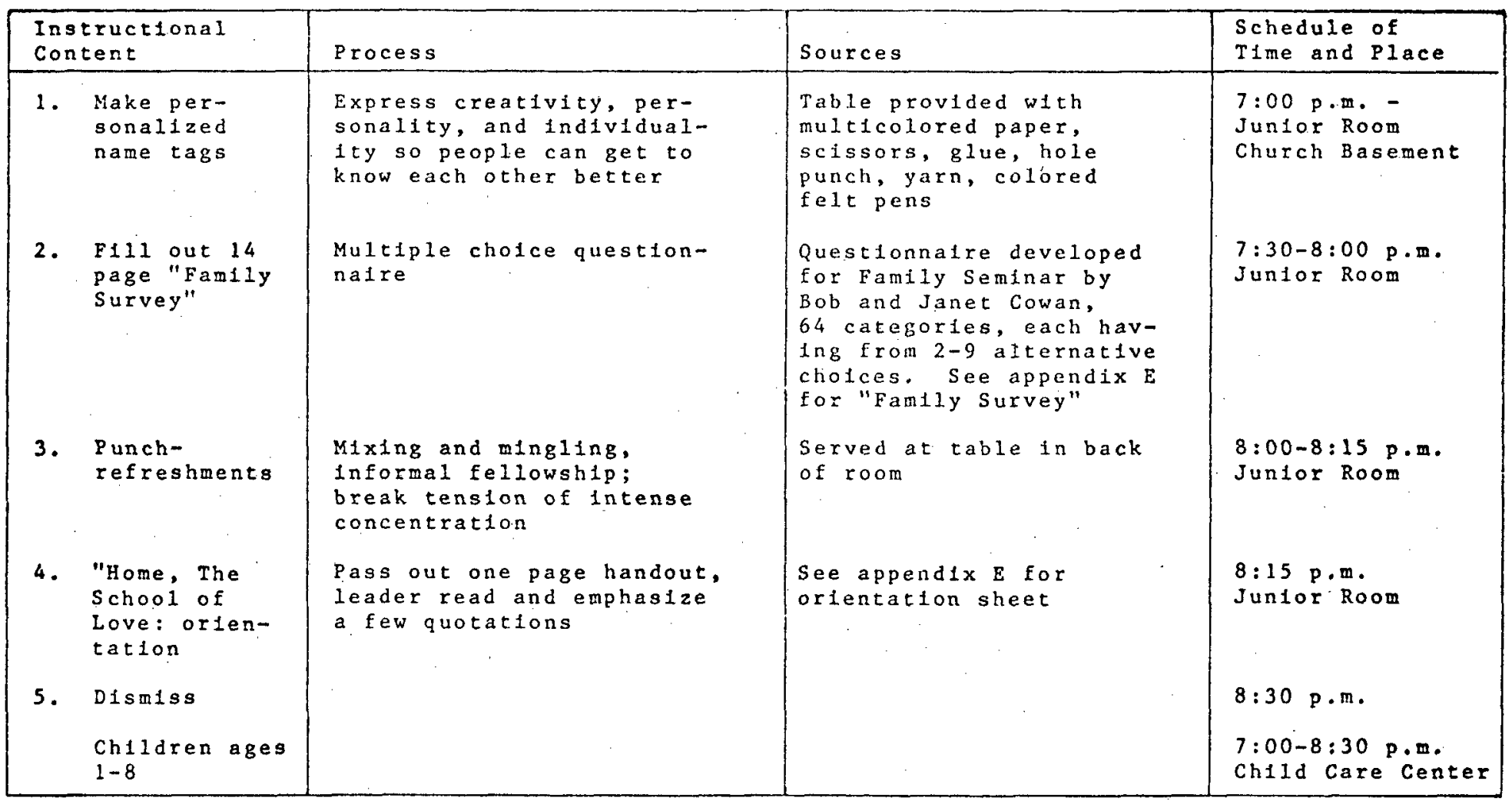


CHART III

SECOND GROUP SESSION, MONDAY, NOVEMBER 18, 1974

object1ves:

1. Allow time for feedback from first group session.

2. To motivate famlifes to develop a private devotional life.

\begin{tabular}{|c|c|c|c|c|}
\hline \multicolumn{2}{|c|}{$\begin{array}{l}\text { Instructional } \\
\text { Content }\end{array}$} & \multirow{2}{*}{$\frac{\text { Process }}{\text { Stand with bowed heads }}$} & \multirow{2}{*}{$\frac{\text { Sources }}{\text { Leader or participant. }}$} & \multirow{2}{*}{$\begin{array}{l}\text { Schedule of } \\
\text { Time and Place } \\
\text { 7:00 p.m. } \\
\text { Juntor Room }\end{array}$} \\
\hline & $\begin{array}{l}\text { Opening } \\
\text { prayer }\end{array}$ & & & \\
\hline 2. & Feedback & $\begin{array}{l}\text { Sit in circle facing each } \\
\text { other; share reactions } \\
\text { from name tags, question- } \\
\text { natres, and orientation }\end{array}$ & $\begin{array}{l}\text { Leader ask Inttial } \\
\text { question or two and } \\
\text { guide fuli group dis- } \\
\text { cussion }\end{array}$ & $\begin{array}{l}7: 02 \text { p.m. } \\
\text { Junior Room }\end{array}$ \\
\hline 3. & $\begin{array}{l}\text { Presentation: } \\
\text { A private de- } \\
\text { votional life } \\
\text { ls essential } \\
\text { ln bullding a } \\
\text { love relation- } \\
\text { ship with God }\end{array}$ & $\begin{array}{l}\text { Leader and participants } \\
\text { seated; handout circulated; } \\
\text { read aloud by leader }\end{array}$ & $\begin{array}{l}\text { "The Key To Success In } \\
\text { Christian Living Is A } \\
\text { Private Devotional Life," } \\
\text { by R. H. Cowan. "A } \\
\text { Clarion Call to God's } \\
\text { Pecple to Come Back to } \\
\text { God's Book" by R. H. } \\
\text { pierson, Review H Hald, } \\
\text { Oct. 31, 1974, pp.4-6. }\end{array}$ & $\begin{array}{l}7: 30 \text { p.m. } \\
\text { Jun1or Room }\end{array}$ \\
\hline & $\begin{array}{l}\text { Sinali group } \\
\text { activity in } \\
\text { fam } 11 \text { y groups }\end{array}$ & $\begin{array}{l}\text { Team up as families and } \\
\text { discuss "What can we do } \\
\text { as a famfly to encourage } \\
\text { each person to develop } \\
\text { private devotional life" }\end{array}$ & $\begin{array}{l}\text { Ideas generated from } \\
\text { within the famtly, pos- } \\
\text { sibly stimulated by } \\
\text { presentation }\end{array}$ & $\begin{array}{l}7: 45 \text { g.m. } \\
\text { Juntor Room }\end{array}$ \\
\hline & Sharling t t me & $\begin{array}{l}\text { Reassemble as large group } \\
\text { and report family tdeas } \\
\text { for all to hear }\end{array}$ & $\begin{array}{l}\text { One member of each family } \\
\text { reports to large group }\end{array}$ & $\begin{array}{l}8: 05 \text { p.m. } \\
\text { Juntor Room }\end{array}$ \\
\hline 6. & $\begin{array}{l}\text { closing } \\
\text { prayer }\end{array}$ & Stand with bowed heads & Leader or participant & $\begin{array}{l}8: 30 \text { p.m. } \\
\text { Junior Room }\end{array}$ \\
\hline & $\begin{array}{l}\text { Ch1ldren ages } \\
1-8\end{array}$ & & & $\begin{array}{l}7: 00-8: 30 \mathrm{pom} \\
\text { Child Care Center }\end{array}$ \\
\hline
\end{tabular}


THIRD GROUP SESSION, TUESDAY, NOVEMBER 19,1974

objectives:

1. To help the particlpants to understand the Importance of conducting regular family worship in the home in order to ald in developing love for God and man.

2. To suggest 1deas on how this goal might be accomplished.

3. To help the participants to begin planning one Frlday evening worship ot home

4. To share 1deas with one another for future family worships.

\begin{tabular}{|c|c|c|c|}
\hline $\begin{array}{l}\text { Instructional } \\
\text { Content }\end{array}$ & Process & Sources & $\begin{array}{l}\text { Schedule } \\
\text { Time and Place }\end{array}$ \\
\hline $\begin{array}{l}\text { Opening } \\
\text { prayer }\end{array}$ & Stand with bowed heads & Des Cummings & $\begin{array}{l}\text { 7:00 p.m. } \\
\text { Junfor Room }\end{array}$ \\
\hline 2. Sharing time & $\begin{array}{l}\text { Sit in circle as a full } \\
\text { group; share fdeas on de- } \\
\text { veloping a private devo- } \\
\text { tional iffe }\end{array}$ & $\begin{array}{l}\text { Leader encourage dis- } \\
\text { cussion }\end{array}$ & $\begin{array}{l}7: 02 \text { p.m. } \\
\text { Junior Room }\end{array}$ \\
\hline $\begin{array}{l}\text { 3. Presentation: } \\
\text { "Fantly } \\
\text { Forslifp" }\end{array}$ & $\begin{array}{l}\text { Andre Stijnman read his } \\
\text { paper on "gamlly Worship" } \\
\text { See appendix E for sample } \\
\text { copy; handed it out after } \\
\text { presentation }\end{array}$ & $\begin{array}{l}\text { Andre st1jnman, handout } \\
\text { on "Fam1ly Worship" }\end{array}$ & $\begin{array}{l}7: 30 \text { p.m. } \\
\text { Juntor Room }\end{array}$ \\
\hline $\begin{array}{l}\text { 4. Small group } \\
\text { activity }\end{array}$ & $\begin{array}{l}\text { Divide up tnto family groups } \\
\text { and plan for famlly worships } \\
\text { in general and for this com- } \\
\text { Ing Friday evening in par- } \\
\text { ticular with longer range } \\
\text { plan for the next } 30 \text { days }\end{array}$ & $\begin{array}{l}\text { Famlly members talking } \\
\text { among themselves }\end{array}$ & $\begin{array}{l}7: 45 \text { p. m. } \\
\text { Juntor RoOm }\end{array}$ \\
\hline 5. Sharing time & $\begin{array}{l}\text { One member of each family } \\
\text { share the family's plans } \\
\text { for family worship, after } \\
\text { full group has reassembled }\end{array}$ & One member per fam11y & $\begin{array}{l}\text { 8:05 p.m. } \\
\text { Jun1 or Room }\end{array}$ \\
\hline $\begin{array}{l}\text { 6. Closing } \\
\text { prayer }\end{array}$ & Standing & & $\begin{array}{l}8: 30 \mathrm{p} \cdot \mathrm{m} . \\
\text { Jun } 1 \text { or Room }\end{array}$ \\
\hline $\begin{array}{l}\text { Children ages } \\
1-8\end{array}$ & & & $\begin{array}{l}7: 00-8: 30 \text { p.i: } \\
\text { Ch11d Care Center }\end{array}$ \\
\hline
\end{tabular}


CHART V

FOURTH GROUP SESSION, WEDNESDAY, NOVEMBER 20, 1974

objective:

To stresa the 1mportance of communication within the family as necessary to the development of love between famly members.

\begin{tabular}{|c|c|c|c|}
\hline $\begin{array}{l}\text { Instructional } \\
\text { Content }\end{array}$ & Process & Sources & $\begin{array}{l}\text { Schedule of } \\
\text { T1me and Place }\end{array}$ \\
\hline 1. Opening prayer & Standing in a circle & Leader or partlcipant & $\begin{array}{l}\text { 7:00 p.m. } \\
\text { Juntor Room }\end{array}$ \\
\hline $\begin{array}{l}\text { 2. Announcement of } \\
\text { evening coplc } \\
\text { "Comintication in } \\
\text { the family" and } \\
\text { Introduction of } \\
\text { resourceperson } \\
\text { Andre stijnman }\end{array}$ & $\begin{array}{l}\text { Leader standing, partici- } \\
\text { pants seated in a circle }\end{array}$ & Bob Cowan & $\begin{array}{l}\text { 7:01 p.m. } \\
\text { Jun10r Room }\end{array}$ \\
\hline $\begin{array}{l}\text { 3. "The Influence } \\
\text { of Television on } \\
\text { family communt- } \\
\text { cation" }\end{array}$ & $\begin{array}{l}\text { Andre's oral presentation; } \\
\text { handout distributed when } \\
\text { finlshed with oral presen- } \\
\text { tation }\end{array}$ & $\begin{array}{l}\text { See appendix E for handout } \\
\text { (Not avallable at this time) } \\
\text {. }\end{array}$ & $\begin{array}{l}7: 02 \text { p.m. } \\
\text { Jun10r Room }\end{array}$ \\
\hline $\begin{array}{l}\text { 4. "Communcation } \\
\text { between parents } \\
\text { and teenagers" }\end{array}$ & $\begin{array}{l}\text { Des cumings oral presenta- } \\
\text { tion, use of blackboard and } \\
\text { poster board for visual a } 1 \text { das }\end{array}$ & No handout distributed & $\begin{array}{l}7: 22 \text { p.m. } \\
\text { Jun10r Room }\end{array}$ \\
\hline $\begin{array}{l}\text { 5. Charlie Shedd's } \\
\text { five gifts that } \\
\text { wil guarantee } \\
\text { aturned-on } \\
\text { marriage" }\end{array}$ & $\begin{array}{l}\text { Bob Cowan distributed three } \\
\text { handoutg and highlighted the } \\
\text { one on "Charlie Shedd's five } \\
\text { glfts..." }\end{array}$ & $\begin{array}{l}\text { See appendix E for handouts } \\
\text { "Charle Shedd's Flve Gifts } \\
\text { - ." and "When I Stopped } \\
\text { Praying for My Famlly." and } \\
\text { "T1me" }\end{array}$ & $\begin{array}{l}\text { 8:02 p.m. } \\
\text { Junior Room }\end{array}$ \\
\hline $\begin{array}{l}\text { 6. Small group } \\
\text { discusston }\end{array}$ & $\begin{array}{l}\text { Teenagers and Juntors form } \\
\text { one group; adults form three } \\
\text { groups }\end{array}$ & $\begin{array}{l}\text { Cowan, Holmes, Stifnman } \\
\text { with adults; Cummings with } \\
\text { teenagers and juntorg }\end{array}$ & $\begin{array}{l}8: 10 \text { p.m. } \\
\text { Jun } 10 \text { r Room }\end{array}$ \\
\hline 7. Closing prayer & Standing & Ray Holmes & $\begin{array}{l}8: 30 \text { p.m. } \\
\text { Jun10r Room }\end{array}$ \\
\hline $\operatorname{Ch}_{1-8} 1 \mathrm{dren}$ ages & & & $\begin{array}{l}7: 00-8: 30 \text { p. If. } \\
\text { Chlld Care Center }\end{array}$ \\
\hline
\end{tabular}




\section{CHART VI}

FIFTH GROUP SESSION, THURSDAY, NOVEMBER 21, 1974

\section{Objectives:}

1. To show that deep, genulne love for God and famly will overflow ln love for all others outside the family.

2. To show that love for others w111 be expressed by witnessing to them about Jesus.

\begin{tabular}{|c|c|c|c|}
\hline $\begin{array}{l}\text { Instructional } \\
\text { Content }\end{array}$ & Process & Sources & $\begin{array}{l}\text { Schedule of } \\
\text { Time and Place }\end{array}$ \\
\hline 1. Opening prayer & Standing in a circle & Leader or participant & $\begin{array}{l}\text { 7:00 p.m. } \\
\text { Junior Room }\end{array}$ \\
\hline $\begin{array}{l}\text { 2. Introduction of } \\
\text { resource person, } \\
\text { Richard Lange }\end{array}$ & & Bob Cowan & $\begin{array}{l}\text { 7:01 p.m. } \\
\text { Jun1or Room }\end{array}$ \\
\hline $\begin{array}{l}\text { 3. "Earth: Theater } \\
\text { of the Universe" } \\
\text { lntroduced and } \\
\text { presented as a } \\
\text { new witnessing } \\
\text { tool }\end{array}$ & $\begin{array}{l}\text { Speaker standing, par- } \\
\text { ticlpants seated fac1ng } \\
\text { screen }\end{array}$ & $\begin{array}{l}\text { Richard Lange, oral In- } \\
\text { troduction then } 29-m i n u t e \\
\text { multimedia presentation } \\
\text { with color slides and } \\
\text { cassette tape recording; } \\
\text { presentation books dis- } \\
\text { played and offered for } \\
\text { sale }\end{array}$ & $\begin{array}{l}7: 02 \text { p.m. } \\
\text { Junior Room }\end{array}$ \\
\hline $\begin{array}{l}\text { 4. Question and } \\
\text { answer period }\end{array}$ & . & Richard Lange & $\begin{array}{l}8: 15 \text { p.m. } \\
\text { Jun1or Room }\end{array}$ \\
\hline 5. Closing prayer & & & $\begin{array}{l}8: 40 \text { p.m. } \\
\text { Junior Room }\end{array}$ \\
\hline $\begin{array}{l}\text { Ch1ldren ages } \\
1-8\end{array}$ & & & $\begin{array}{l}7: 00-8: 30 \text { p.m. } \\
\text { Child Care Center }\end{array}$ \\
\hline
\end{tabular}


WORSHIP SERVICE, SABBATH, NOVEMBER 23, 1974

objectives:

1. To explain that Jesus' goal for the Christian 1s that he love others as Jesus loved him.

2. To motivate the congregation to become involved In developing this deep love.

\begin{tabular}{|c|c|c|c|}
\hline $\begin{array}{l}\text { Instructional } \\
\text { Content }\end{array}$ & Process & Sources & $\begin{array}{l}\text { Schedule of } \\
\text { Time and Place }\end{array}$ \\
\hline 1. Invocation & $\begin{array}{l}\text { Prayer for God's bless- } \\
\text { ing and guidance in wor- } \\
\text { ship service as we con- } \\
\text { tinue to focus on the } \\
\text { family. }\end{array}$ & $\begin{array}{l}\text { Personal thought given } \\
\text { In advance of service }\end{array}$ & $\begin{array}{l}11: 00 \text { a.m. Benton } \\
\text { Harbor Advent1st } \\
\text { Church }\end{array}$ \\
\hline 2. Opening hymn & Congregational singing & $\begin{array}{l}\text { Church Hymnal, \#142, } \\
\text { "Love Divine" }\end{array}$ & $11: 01 \mathrm{a} \cdot \mathrm{m}$. \\
\hline $\begin{array}{l}\text { 3. Scripture and } \\
\text { prayer }\end{array}$ & $\begin{array}{l}\text { Read aloud by.C. Raymond } \\
\text { Holmes }\end{array}$ & Jn $13: 31-35$ & $11: 07$ a.m. \\
\hline 4. ChIldren's story & $\begin{array}{l}\text { Bob Cowan gathered children } \\
\text { up front and told them a } \\
\text { story of personal experience; } \\
\text { lesson: obedience }\end{array}$ & $\begin{array}{l}\text { "When Bobby Got B1tten } \\
\text { by a Donkey" }\end{array}$ & $11: 12$ a.m. \\
\hline 5. Sermon & $\begin{array}{l}\text { Bob Cowan expository sermon; } \\
30 \text { minutes, "Jesus Gave a } \\
\text { New Commandment: Love Others } \\
\text { as he Loved Us" }\end{array}$ & $\begin{array}{l}\text { See appendix E for sermon } \\
\text { outline }\end{array}$ & $11: 30 \mathrm{e} \cdot \mathrm{m}$. \\
\hline 6. Closing hymn & Congregational singling & $\begin{array}{l}\text { Church Hymnal, \#533, } \\
\text { "On a H111 Far Away". }\end{array}$ & $12: 00$ Noon \\
\hline 7. Benediction & Des Cummings & $\begin{array}{l}\text { Prayer for enablement } \\
\text { to accomplish goals } \\
\text { presented }\end{array}$ & $12: 05 \mathrm{p} . \mathrm{m}$. \\
\hline
\end{tabular}


CHART VIII

SIXTE GROUP SESSION, SABBATH, NOVEMBER 23, 1974

objectives:

1. Io present the need for discipline within the framework of love among famliy members.

Dre

3. To peralt participants to evaluate seminar.

\begin{tabular}{|c|c|c|c|}
\hline $\begin{array}{l}\text { Instructional } \\
\text { Content }\end{array}$ & Process & Sources & $\begin{array}{l}\text { Schedule of } \\
\text { Time and Place }\end{array}$ \\
\hline 1. Opening prayer & Standing in a circle & Bob Cowan & $\begin{array}{l}\text { 1:30 p.m. Benton } \\
\text { Harbor Advent1st } \\
\text { Church }\end{array}$ \\
\hline $\begin{array}{l}\text { 2. Sharing of Friday } \\
\text { evening famliy } \\
\text { worships at home }\end{array}$ & Large group discussion & $\begin{array}{l}\text { One member of each family } \\
\text { reported on previous night; } \\
\text { Bob Cowan discussion leader }\end{array}$ & $1: 32 \mathrm{p} \cdot \mathrm{m}$. \\
\hline 3. "Love Discipline" & Oral presentation & Deg Cummings & $1: 45 \mathrm{p.m}$. \\
\hline $\begin{array}{l}\text { 4. Response to calk on } \\
\text { "Love Discipline" } \\
\text { Questions about } \\
\text { entire seminar }\end{array}$ & Large group discussion & Bob Cowan, discussion leader & $2: 30 \mathrm{p} \cdot \mathrm{m}$. \\
\hline $\begin{array}{l}\text { 5. Evaluation of } \\
\text { seminar }\end{array}$ & $\begin{array}{l}\text { Evaluation forms pasied } \\
\text { out and completed by } \\
\text { particlpants }\end{array}$ & $\begin{array}{l}\text { See appendix E for evaluation } \\
\text { form }\end{array}$ & $3: 10 \mathrm{p} \cdot \mathrm{m}$. \\
\hline $\begin{array}{l}\text { 6. Planning for } \\
\text { future meeting }\end{array}$ & Discussion by laxge group & $\begin{array}{l}\text { Decided on Sabbath, December } \\
14 \text { for potluck and posttest } \\
\text { gurvey }\end{array}$ & $3: 25 \mathrm{p} . \mathrm{m}$. \\
\hline $\begin{array}{l}\text { 7. Gift books offered } \\
\text { to particlpants }\end{array}$ & E1der Holmes, announcement & $\begin{array}{l}\text { Cholce of one book per family } \\
\text { Happinegs Homemade or By falth } \\
\text { I Live; B Bble Readlngs for the } \\
\text { Home (one for each family) }\end{array}$ & $3: 28 \mathrm{p} \cdot \mathrm{m}$. \\
\hline closing prayer & seanding & Elder Molmes & $3: 29 \mathrm{p.m}$. \\
\hline 9. Song & $\begin{array}{l}\text { Spontaneougly led by a par- } \\
\text { ticlpant }\end{array}$ & "Blest Be the Tie that Binds" & $3: 30 \mathrm{p} \cdot \mathrm{m}$. \\
\hline Offering & $\begin{array}{l}\text { Announcewent that an offering } \\
\text { basket would be near exit } \\
\text { door to help with expenses }\end{array}$ & Elder Holmes & $3: 31 \mathrm{p} \cdot \mathrm{m}$. \\
\hline Ch11dren Ages $1-8$ & & & $\begin{array}{l}1: 30-3: 30 \\
\text { Ch11d Care }\end{array}$ \\
\hline
\end{tabular}




\section{The Data Reported}

There were two kinds of data gathered from the participants: (1) an evaluation sheet at the sixth group session and (2) a pretest and posttest "Family Survey." They will be reported in the sequence listed above.

\section{Evaluation Sheets}

The evaluation sheets were distributed to all present, and forty-six people completed and returned them at the sixth group session. Each sheet contained four subjective questions and one objective question. A brief summary of the evaluation forms will be provided here. ${ }^{1}$

The first question was "What happened in the seminar that was the most helpful to you?" A wide variety of responses to this question were given. Some responses were subject oriented. They mentioned topics like "daily devotionals," "love discipline," "communication," and" television." other responses were leader oriented. They expressed appreciation for specific leaders on the staff. Still others responded by expressing favor toward the openness of the group process and sharing of ideas that took place in the relaxed atmosphere of the informal fellowship. One participant appreciated "having children cared for so you [could] function with all your thoughts." There were no negative comments offered here. The most common

\footnotetext{
${ }^{1}$ For a verbatim summary of evaluation sheets, see appendix E.
} 
response to the question was "everything," or "all of it." Question two was: "What happened in the seminar that was the least helpful to you?"

Three people responded that the Thursday evening film on witnessing was the least helpful. Other responses suggested the television presentation because they didn't "have one anyway," the seminar "went too fast," there was "not enough time given to each subject area," and "I work a11 day and in the evening I am very tired." The most common response to this question was that "nothing" was least helpful or "everything was helpful."

Question three asked: "What suggestions would you have to improve the seminar?"

The answers to this question suggested having "more evenings" devoted to the seminar, "have a question and answer period," to have more discussions with the total group "rather than family" groups, "call on the kids more," have "a follow-up plan for the church," publicize it better so "more families" could attend, "concentrate on fewer subjects," have a "stronger emphasis on husband-wife relationships," get more "teens" to attend, use a "P.A. system" so participants could hear discussions better, and "have them more often." The most common answer was "none." Question four was: "Comments you would like to share."

One person suggested having a fellowship group like this once a month "instead of regular prayer meeting." 
Another said he (or she) was not really enthused about the seminar in the beginning but as the seminar progressed it "was very interesting and you changed my mind."

The most frequent comments expressed personal enjoyment and benefit: "I really think it helped me [a] 1ot." "This seminar was just [the] thing I needed to give my relationship a lift." "This seminar has drawn us closer together as a church." "Our church's love-quotient and trust-quotient has (sic) been raised."

Question five asked the participants to give an "overall evaluation" of the seminar by checking one of four alternatives: "excellent," "good," "fair," or "poor." of the forty-six people who filled out the evaluation forms, thirty-six checked "excellent," six checked "good," two checked both "excellent" and "good," one checked half-way between "excellent" and "good," one did not check any of the four, and none checked either "faix" or "poor."

\section{Family Surveys}

The data from the Family Surveys were analyzed by a computer and sorted into four categories: (1) pretest, low frequency attendance, (2) pretest, high frequeucy attendnace, (3) posttest, low frequency attendance, and (4) posttest, high frequency attendance. Low frequency attendance indicated the participants' presence at from one to three group sessions, while high frequency attendance was defined as involvement in four to six group sessions. Eight people 
were in the first category as compared to forty-five people in the latter group, making a total of fifty-three respondents.

The biographical data indicated that the group was. almost evenly divided between males and females; the age spread ranged from age 9-60; the occupational spread included some people in a11 categories between students and professionals; most participants were married once and still living with the same spouse; the length of marriage for particpants spanned from "1-3 years" to "40 or more years"; the majority were Seventh-day Adventists; most participants and their spouses had been SDAs for "21-40" years; and most had either graduated from some college or had taken some college work.

The remaining data have only been reported here in categories where there was an observed change (postive or negative) in the total group response at the posttest as compared to the pretest. No negative changes in response were observed in the data. A change was observed if it involved two or more of the eight people who responded from the low frequency attendance group, or if it involved eight or more of the forty-five people with a high frequency of attendance. Responses were considered positive if they moved in the direction of increasing love and negative if they reflected decreasing love. These responses are reported in the following statistical table. They will be interpreted in chapter VI. 
TABLE I

Observed Change

From Pretests to Posttests

\begin{tabular}{|c|c|c|c|c|c|c|c|c|c|c|}
\hline \multirow{3}{*}{$\begin{array}{l}\text { Question } \\
\text { Answer }\end{array}$} & \multirow{3}{*}{$\begin{array}{l}\text { Subject } \\
\text { Category }\end{array}$} & \multicolumn{4}{|c|}{ Low Frequency Att. } & \multicolumn{4}{|c|}{ High Frequency Att. } & \multirow{3}{*}{$\begin{array}{l}\text { Change } \\
\text { in } \% \\
\text { of Total }\end{array}$} \\
\hline & & \multicolumn{2}{|c|}{ Pretest } & \multicolumn{2}{|c|}{ Posttest } & \multicolumn{2}{|c|}{ Pretest } & \multicolumn{2}{|c|}{ Posttest } & \\
\hline & & No. & $\%$ & No. & $\%$ & No. & $\%$ & No. & $\%$ & \\
\hline $16: 2$ & Faith/Works & 4 & 50 & 6 & 75 & & & & & 25.0 \\
\hline $20: 0$ & $\begin{array}{l}\text { No private } \\
\text { devotions }\end{array}$ & & & & & 17 & 37.7 & 8 & 17.7 & 20.0 \\
\hline $22: 1$ & $\begin{array}{l}\text { Pers. dev. } \\
\text { enjoyment }\end{array}$ & & & & & 26 & 57.7 & 38 & 84.4 & 26.7 \\
\hline $23: 1$ & $\begin{array}{l}\text { Pers. dev. } \\
\text { eagerness }\end{array}$ & & & & & 14 & 31.1 & 27 & 60.0 & 28.9 \\
\hline $29: 9$ & $\begin{array}{l}\text { Actions: } \\
\text { love for Jesus }\end{array}$ & & & & & 12 & 26.6 & 24 & 53.3 & 26.7 \\
\hline $30: 3$ & $\begin{array}{l}\text { Increased love } \\
\text { for others }\end{array}$ & & & & & 18 & 40.0 & 31 & 68.8 & 28.8 \\
\hline $31: 5$ & $\begin{array}{l}\text { Belief in } \\
\text { love for Jesus }\end{array}$ & & & & & 26 & 57.7 & 37 & 82.2 & 24.5 \\
\hline $60: 3$ & $\begin{array}{l}\text { Witness, a } \\
\text { life style }\end{array}$ & & & & & 8 & 17.7 & 16 & 35.5 & 17.8 \\
\hline $61: 2$ & $\begin{array}{l}\text { Love in } \\
\text { witnessing }\end{array}$ & 2 & 25 & 6 & 75 & & & & & 50.0 \\
\hline $61: 2$ & $\begin{array}{l}\text { Love in } \\
\text { witnessing }\end{array}$ & & & & & 13 & 28.8 & 22 & 48.8 & 20.0 \\
\hline
\end{tabular}




\section{CHAPTER V}

\section{THE HEMET SEMINAR}

\section{Introduction}

The second seminar on Home, The School of Love was held in Southern California after the writer's period of residence at Andrews University had been completed. It was anticipated that there would be at least four significant differences between the two seminars: (1) the seminar leader would be conducting a seminar for his own church rather than as a consultant in someone else's church, (2) the seminar would be held over one weekend (including Friday evening, a 11 day Sabbath, and Sunday morning) instead of over an eight-day period, (3) the resource personnel at Andrews University would not be available in Hemet, and (4) certain improvements learned from the Benton Harbor seminar would be incorporated in the Hemet seminar.

These differences will be discussed first, then the procedure for scheduling the seminar will be presented, charts will be provided to show the outline for each of the seminar sessions, and the evaluation data will be reported. 
Functioning as a Consultant Compared to Leading a Seminar in One's own Church

Before any areas of difference between the writer's role as a consultant in someone else's church are compared with his role as the pastor in his own church one similarity should be pointed out first. The leader attended the Benton Harbor church for about six months before he conducted his first seminar, and he attended the Hemet church for eight months before he conducted his second seminar. So in both cases he was known to the people in the churches (and therefore to the seminar participants) a relatively short time before the seminars began.

In contrast, a pastor of a church acquainted with his members for several years instead of eight months might be expected to begin a seminar with a stronger base of support and confidence from his people than had been estabIished here. However, the writer did not perceive that being relatively unknown was a deterrent either in the number of participants who took part or in the benefits received by the participants in the seminars. The leader's credibility had been adequately established in both churches. In Benton Harbor, his credibility was established by the approval of the pastor, the board, the Seminary, and his six-months presence in the church preceding the seminar. In Hemet, his credibility came from his appointment as pastor of the church by the conference and the added 
influence of having already conducted one such seminar in Michigan .

As for differences between the consultant's role compared with the pastor's role, only two were observed. First, a somewhat greater degree of credibility was extended to him in his role as the pastor than in his role as consultant. This difference is perhaps derived from a congregation's ready acceptance of one who has been designated as their pastor by the conference committee, rather than of one who is a student--a subordinate role in the minds of many. However, if a consultant who was an official of the local, union, or General Conference, such as Ministerial Secretary, came to conduct a seminar in the church most people would tend to perceive him as a resource person in a superior position than their local pastor. Second, a full time pastor sees his congregation more often and in more places than does a consultant. He sees them in their homes, at prayer meetings, church socials, and board meetings, in addition to sabbath mornings. The student consultant who attends their church is with the people only one morning per week. Because of this, the student consultant is at a disadvantage because the congregation does not know him as well and will not accept him as readily as they would the pastor. Hence, a consultant who is perceived as a subordinate by a congregation operates at a disadvantage. 
might occasionally occur, although it was not observed in this study. Some people might talk more openly to a consultant who would be available for only a short time than they would to their pastor.

\section{The Eight-day Format as Compared to the Three-day Format}

After having conducted both kinds of seminars, the writer observed advantages and disadvantages for both styles. It is generally true that the disadvantages of one style become advantages in the other style. Therefore the advantages of each style will be discussed. First, it should be stated clearly that in the opinion of this writer both styles were successful. In so saying, he is not limiting the possibilities to these two kinds of time format and other time schedules may emerge in future seminars.

The Advantages of the Eight-day Seminar

The principal advantage is that the cost of participation is kept at its lowest possible point when held at a local facility. ${ }^{1}$ No extra cost is incurred for housing, meals (each family provides its own), or transportation to and from a distant seminar site. ${ }^{2}$

$1_{\text {The treasurer of the Benton Harbor church reported }}$ a cost of $\$ 80$ for the fifty people who attended the seminar.

2 The cost of the Hemet Seminar (at Pine springs Ranch) was $\$ 294.35$ for food, lodging, and seminar materials for thirty people. 
Another advantage is that the participants can assimilate the ideas presented in the seminar over a longer time period. Hence, the possibility of the ideas influencing the participants would be expected to be greater.

In addition, the family members are all sleeping in their own familiar beds each night and eating their own familiar food so they are not being required to make any extra adaptations in thejr physical environment. Their Iife-style is disrupted very little.

The Advantages of the Three-day Seminar The principal advantage of the three-day seminar is the continuity achieved when the participating group is away from home. Participants who traveled to a seminar site away from their homes and paid for room and board attended the seminar sessions more regularly than did the participants who stayed close to the distractions of home.

It also appeared that the greater concentration of seminar presentations in a shorter time span provided a more comprehensive view of the objectives of the seminar. The minimum of time between meetings made it easier for the participants to remember what had happened before.

\section{Differences in Resource People}

Inasmuch as four Doctor of Ministry students and one nonstudent minister shared the leadership of the first seminar while one leader conducted the second seminar alone, 1t was expected that there would be less variety in the 
skills and personality of the leadership at the second seminar.

However, the second seminar had among its participants two resource people (each of whom was a certified marriage couselor) that the first seminar did not have. Their input during the second seminar helped to make up for the lack of additional resource personnel.

The fact that each participant in both seminars was considered a resource person introduced a significant variable between the two seminars, since the participants were different in each seminar.

Improvements in the Hemet Seminar from Lessons Learned in the Benton Harbor Seminar Age of Participants

In most cases, it was found that age nine, the minimum age level in the first seminar, was too young for participants to benefit from the seminar. Therefore, in the second seminar, the minimum age level for participants was raised to twelve.

\section{Witnessing Module}

The witnessing module during the first seminar was included because it was (1) available, (2) new, and (3) expected to be significantly helpful in inspiring church members to witness for Christ. The feedback received from the first participants led to a change of approach for the presentation on witnessing in the second seminar. 
This change of approach places no value judgment on the person who gave the first presentation on witnessing nor on the materials that were presented on that occasion. Rather the writer believes that the resource person was inadequately informed of the seminar's format and objectives and that uniformity in the approach to each seminar session is very advantageous. While some variety does introduce an element of interest in the seminar, too much variation from the standard seminar format causes learning productivity to decrease.

\section{Seminar Scheduling Procedure}

After the seminar leader had been the pastor of the Hemet church for a few months, he recommended to the church board that a Family Spiritual Enrichment Seminar be conducted for the church members in a retreat setting. The board warmly received the idea and gave its approval.

Subsequently, a variety of retreat sites were investigated for possible seminar locations. Pine Springs Ranch, the Southeastern California Conference camp, was chosen as idea1. The camp facilities were booked far in advance; however, a cancellation by one of the church groups made it available the weekend of october 10-12, 1975. Applications were prepared and distributed to the members of the Hemet church and plans were organized to implement the seminar. Two Adventist families from beyond the Hemet area who submitted applications were granted permission to attend. 
Since so much time was required to fill out the

Family Survey questionnaixe during the first evening meeting of the Benton Harbor seminar, it was decided and implemented that the participants should receive their questionnaires prior to the seminar and be asked to fill them out and return the completed questionnaires at Pine springs Ranch.

The meeting schedule for the seminar, the subject outlines for the sessions' schedules, the outlines of each session in chart form, and the evaluation data follow:

\section{Meeting Schedule}

Friday, October 10,1975

$$
\begin{aligned}
& \text { 3-5 p.m. } \\
& 5: 30 \mathrm{p} \cdot \mathrm{m} \text {. } \\
& 6: 15 \mathrm{p} \text {. m. } \\
& 6: 30 \text { p.m. } \\
& 8: 00 \text { p.m. } \\
& 8: 10 \text { p.m. } \\
& 8: 30 \mathrm{p} \cdot \mathrm{m} \text {. } \\
& \text { 10:00 p.m. }
\end{aligned}
$$

\footnotetext{
$7: 45 \mathrm{a} \cdot \mathrm{m}$.

9:00 a.m.

$10: 30$ a.m.

$10: 40 \mathrm{a} . \mathrm{m}$.

12:00 noon

$12: 30 \mathrm{p} . \mathrm{m}$.

$1: 30 \mathrm{p} \cdot \mathrm{m}$.

3:00 p.m.

4:15 p.m.

4:25 p.m.

$5: 15$ p.m.

$5: 30$ p.m.

$6: 15$ p.m.
}

Arrival, Locating, Return Questionnaire, Make Personalized Name Tags--Lodge

Supper--Cafeteria

* Sundown Worship--Lodge

lst Seminar Session

Break

2nd Seminar Session

$* *$ Dismissal

Quiet Time

Sabbath, October 11, 1975

Breakfast--Cafeteria

*3rd Seminar Session--Lodge

Break

4 th Seminar Session--Lodge

$\star *$ Dismissal

Dinner--Cafeteria

Free Time

* 5 th Seminar Session--Lodge

Break

6 th Seminar Session--Lodge $* *$ Dismissa 1

Supper--Cafeteria

Sundown Worship as Separate Families

wherever you wish. 


\section{Meeting Schedule--continued}

\begin{tabular}{|c|c|c|c|}
\hline $6: 30$ & $\mathrm{p} \cdot \mathrm{m}$. & $* 7$ th Seminar & Session--Lodge \\
\hline $8: 00$ & $\mathrm{p} \cdot \mathrm{m}$. & Break & \\
\hline $\begin{array}{l}8: 10 \\
9: 10\end{array}$ & $\mathrm{P} \cdot \mathrm{m}$. & $\begin{array}{r}8 \text { th Seminar } \\
* * \text { Dismissa } 1\end{array}$ & Session--Lodg \\
\hline $10: 00$ & p.m. & Quiet Time & \\
\hline
\end{tabular}

Children's meetings, for those below 12 years of age, will be conducted by Donna Myers, Mark Froning and Bill Keresoma.

Sunday, October i2, 1975

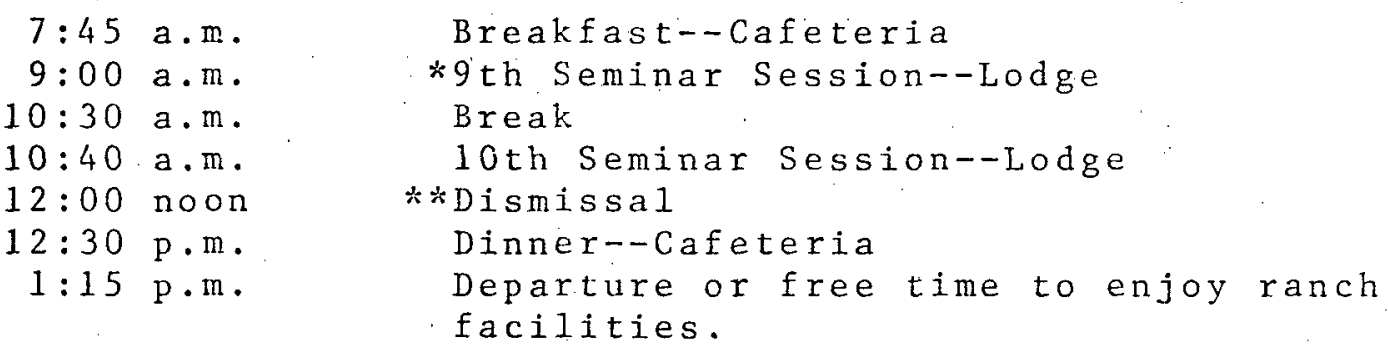

*Children's Meeting Begins--Multi-purpose Room **Children's Meeting Dismisses

\section{Subject Outline for Seminar Sessions}

1st Seminar Session: Get acquainted, orientation and keynote address, "Home, the School of Love".

2nd Seminar Session: Feedback and Discussion

3rd Seminar Session: Private Devotional Life

4th Seminar Session: Family Worship

5 th Seminar Session: Communication in the Family

6 th Seminar Session: Communication in the Family, continued

7 th Seminar Session: Love Discipline

8th Seminar Session: Family Games (N.A.S.A. Forced Choice Game )

9 th Seminar Session: Strategy for Witnessing

loth Seminar Session: Group Discussion and Evaluation 
CHART IX

objectives

FIRST SEMINAR SESSION, FRIDAY, OCTOBER 10, 1975

1. To have sundown worship together.

2. To get acqualnted with each other.

3. To provide the particlpants with an overali orlentation to the Seminar.

4. Keynote address, "Home, The School of Love".

\begin{tabular}{|c|c|c|c|}
\hline $\begin{array}{l}\text { Instructional } \\
\text { Content }\end{array}$ & Process & Sources & $\begin{array}{l}\text { Schedule of } \\
\text { Ilme and Place }\end{array}$ \\
\hline $\begin{array}{l}\text { 1. Sundown } \\
\text { worsh1p }\end{array}$ & $\begin{array}{l}\text { Participants seated in } \\
\text { one large circle; Elder } \\
\text { Cowan led in brief wor- } \\
\text { ship talk and prayer }\end{array}$ & $\begin{array}{l}\text { DA } 633-\text { Christians can } \\
\text { hasten the Lord's re:- } \\
\text { turn. DA } 509-\text { The way } \\
\text { to hasten His return } \\
\text { is by a change of human } \\
\text { hearts. p.E.T. } 201- \\
\text { Motivation for change is } \\
\text { increased in a person who } \\
\text { particlpates in decision } \\
\text { to change }\end{array}$ & $\begin{array}{l}6: 15 \mathrm{p} \cdot \mathrm{m} . \\
\text { Lodge }\end{array}$ \\
\hline $\begin{array}{l}\text { 2. Get } \\
\text { acquainted }\end{array}$ & $\begin{array}{l}\text { Each porticlpant ex- } \\
\text { plains their persona- } \\
\text { lized name tag }\end{array}$ & Participants & $\begin{array}{l}6: 30 \mathrm{p} \cdot \mathrm{m} . \\
\text { Lodge }\end{array}$ \\
\hline 3. Orientation & $\begin{array}{l}\text { Handout distributed and } \\
\text { hlghlighted by leader, } \\
\text { Elder Cowan }\end{array}$ & $\begin{array}{l}\text { See appendix E for } \\
\text { "Orientation" handout. }\end{array}$ & $\begin{array}{l}\text { 7:10 p.m. } \\
\text { Lodge }\end{array}$ \\
\hline $\begin{array}{l}\text { 4. Keynote ad- } \\
\text { dress, } \\
\text { "Home, The } \\
\text { School of } \\
\text { Love" }\end{array}$ & $\begin{array}{l}\text { Elder Cowan presented } \\
\text { his keynote message } \\
\text { orally while seated } \\
.\end{array}$ & $\begin{array}{l}\text { See appendix E for } \\
\text { "Home, the School of } \\
\text { Love" sermon notes }\end{array}$ & $\begin{array}{l}7: 30 \text { p.m. } \\
\text { Lodge }\end{array}$ \\
\hline 5. Break & Recess & & $\begin{array}{l}8: 00 \mathrm{p} \cdot \mathrm{m} . \\
\text { Lodge }\end{array}$ \\
\hline $\begin{array}{l}\text { Children } \\
\text { ages } 1-11\end{array}$ & & & $\begin{array}{l}6: 15-8: 00 \text { p.m. } \\
\text { Nult1-purpose Room }\end{array}$ \\
\hline
\end{tabular}




\section{CHART $\mathrm{X}$}

SECOND SEMINAR SESSION, FRIDAY, OCTOBER 10, 1975

objective:

To provide opportunity. for feedback and discussion based on first seminar session.

\begin{tabular}{|c|c|c|c|}
\hline $\begin{array}{l}\text { Instructional } \\
\text { Content }\end{array}$ & Process & Sources & $\begin{array}{l}\text { Schedule of } \\
\text { Ilme and Place }\end{array}$ \\
\hline $\begin{array}{l}\text { 1. Feedback } \\
\text { and dis- } \\
\text { cussion }\end{array}$ & $\begin{array}{l}\text { Particlpants seated in } \\
\text { ore large circle, } \\
\text { leader glve opportunity } \\
\text { for discussion }\end{array}$ & $\begin{array}{l}\text { Participants and leader } \\
\text { interacting and respon- } \\
\text { ding verbaliy to one } \\
\text { another }\end{array}$ & $\begin{array}{l}8: 10 p \cdot m \\
\text { Lodge }\end{array}$ \\
\hline $\begin{array}{l}\text { 2. Dismissa } 1 \\
\text { ChIldren } \\
\text { ages } 1-11\end{array}$ & $\begin{array}{l}\text { Stand for closing } \\
\text { prayer }\end{array}$ & Leader or participant & $\begin{array}{l}8: 30 \mathrm{p} \cdot \mathrm{m} . \\
\text { Lodge } \\
8: 00-8: 30 \mathrm{p} \cdot \mathrm{m} . \\
\text { Nult } 1 \text {-purpose Room }\end{array}$ \\
\hline
\end{tabular}




\section{CHART XI}

THIRD SEMINAR SESSION, SABBATH, OCTOBER 11,1975

\section{Objectives:}

1. To explain the 1mportance of having a private devotional life in developing love for God, family and others.

2. To make suggestions on how to have a meaningful private devotional. Iffe.

3. To give families an opportuntty to help each other schedule time for a private devotional life.

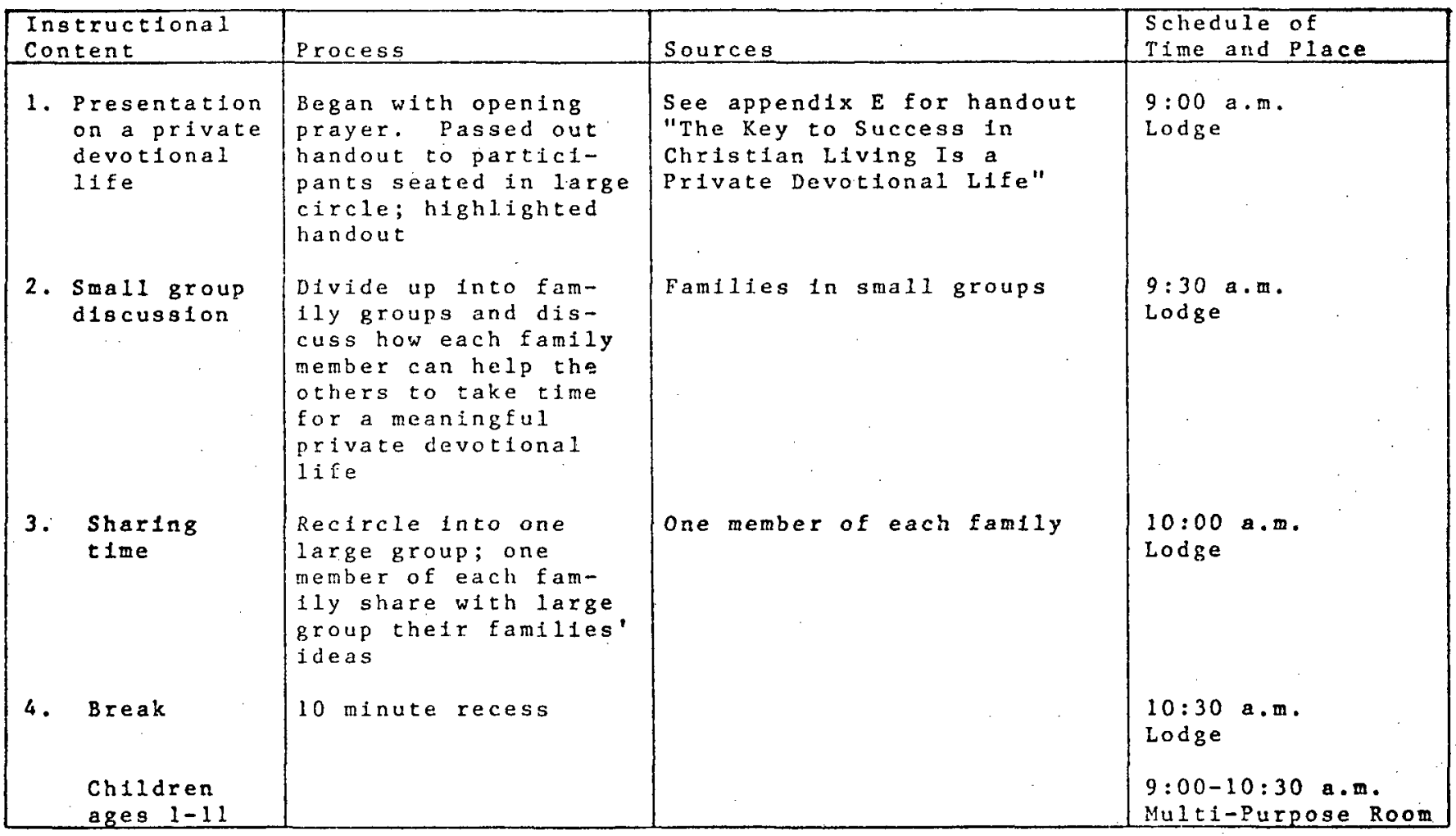




\section{CHART XII}

FOURTH SEMINAR SESSION, SABBATH, OCTOBER 11, 1975

\section{objectives:}

1. To show that a regular meaningful. family worship 1 g essential to spirttual growth.

2. To explain that spiritual growth is best measured in terms of deepening ove relationships.

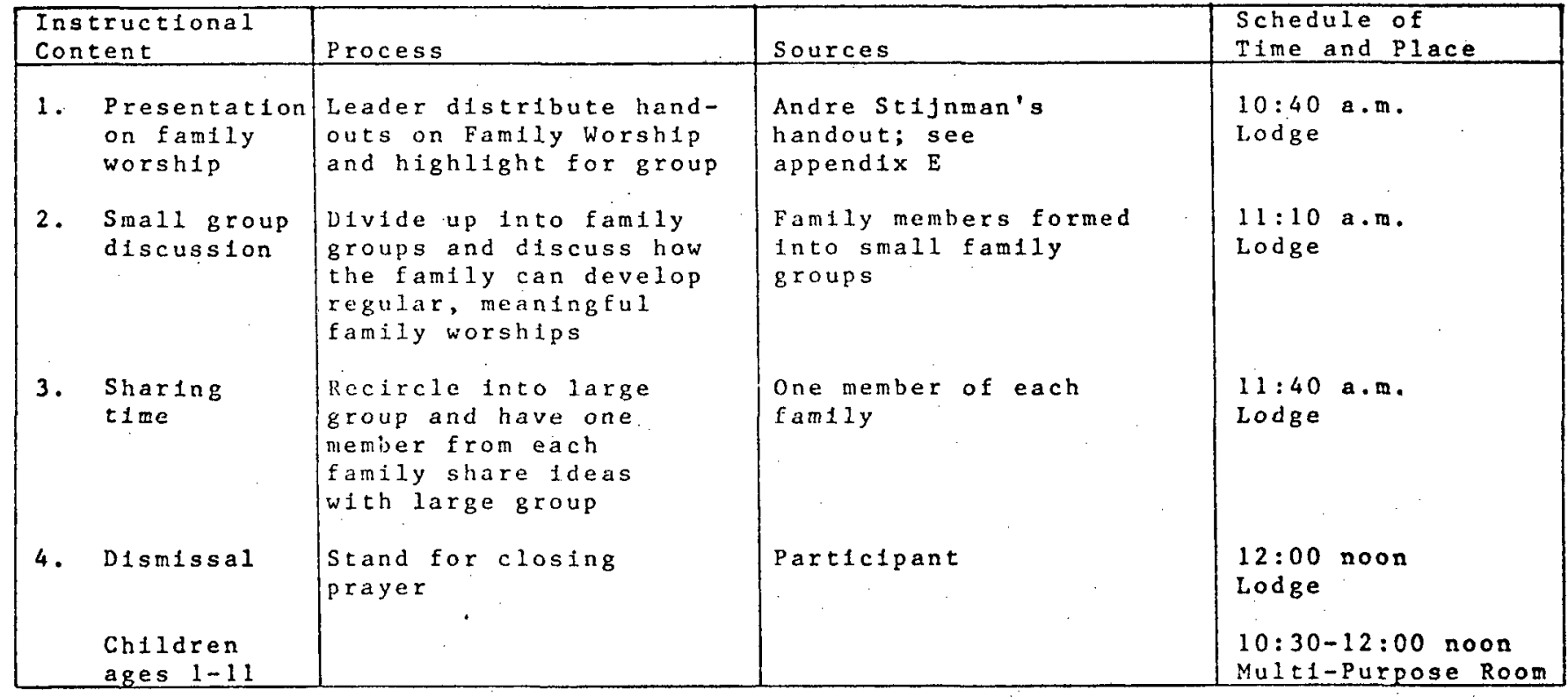


CHART XIII

PIFTH SEMINAR SBSSION, SABBATH, OCTOBER 11,1975

objectives:

1. To point out how television can interfere with famlly communtcation.

2. To point out the importance of good comminication betwcen parents and teenagers.

3. To stress the importance of Improved husband-wife communication.

\begin{tabular}{|c|c|c|c|}
\hline $\begin{array}{l}\text { Instructional } \\
\text { Content }\end{array}$ & Process & Sources & $\begin{array}{l}\text { Schedule of } \\
\text { Time and Place }\end{array}$ \\
\hline $\begin{array}{l}\text { 1. Presentation, } \\
\text { "How Tele- } \\
\text { v1sion Inter- } \\
\text { feres with } \\
\text { Eamlly Com- } \\
\text { munlcation" }\end{array}$ & $\begin{array}{l}\text { Elder Cowandistributed } \\
\text { Andre Stifnman's hand- } \\
\text { out on that toplc and } \\
\text { highlighted 1t }\end{array}$ & Handout not avallable & \\
\hline $\begin{array}{l}\text { 2. Presentation } \\
\text { on "reenager- } \\
\text { Parent com- } \\
\text { muntcation" }\end{array}$ & $\begin{array}{l}\text { clen chinn, a seminaz } \\
\text { participant and the } \\
\text { Chief Probation officer } \\
\text { for the Hemet offlce of } \\
\text { Rlverside county Prob. } \\
\text { Dept spoke briefly then } \\
\text { led into large group } \\
\text { discussion. }\end{array}$ & $\begin{array}{l}\text { Mr. Chinn. No handout } \\
\text { distributed; no notes } \\
\text { avatlable. }\end{array}$ & $\begin{array}{l}3: 15 \mathrm{p} \cdot \mathrm{m} . \\
\text { Lodge }\end{array}$ \\
\hline $\begin{array}{l}\text { 3. Presentation } \\
\text { "Charlie } \\
\text { Shedd's Five } \\
\text { Gifts chat } \\
\text { hill Guar- } \\
\text { antee a } \\
\text { Turned-on } \\
\text { Marriage - } \\
\text { and Gulde- } \\
\text { lines for } \\
\text { Parents" }\end{array}$ & $\begin{array}{l}\text { Elder cowan distributed } \\
\text { handouts and highlighted } \\
\text { thein. }\end{array}$ & $\begin{array}{l}\text { See appendix E for } \\
\text { sample handouts. }\end{array}$ & $\begin{array}{l}\text { 3:50 p.m. } \\
\text { Lodge }\end{array}$ \\
\hline 4. Break & 10-minute recesa & & $\begin{array}{l}4: 15 \mathrm{p} \cdot \mathrm{m} . \\
\operatorname{Lodge}\end{array}$ \\
\hline $\begin{array}{l}\text { Children } \\
\text { ages } 1-11\end{array}$ & & & $\begin{array}{l}3: 00-4: 15 \text { p.m. } \\
\text { Mult1-Purpose Room }\end{array}$ \\
\hline
\end{tabular}


CHART XIV

objective:

SIXTH SEMINAR SESSION, SABBATH, OCTOBER 11,1975

1. To practice communication skilis by means of three exercises; paraphrasing, active listening; building blocks.

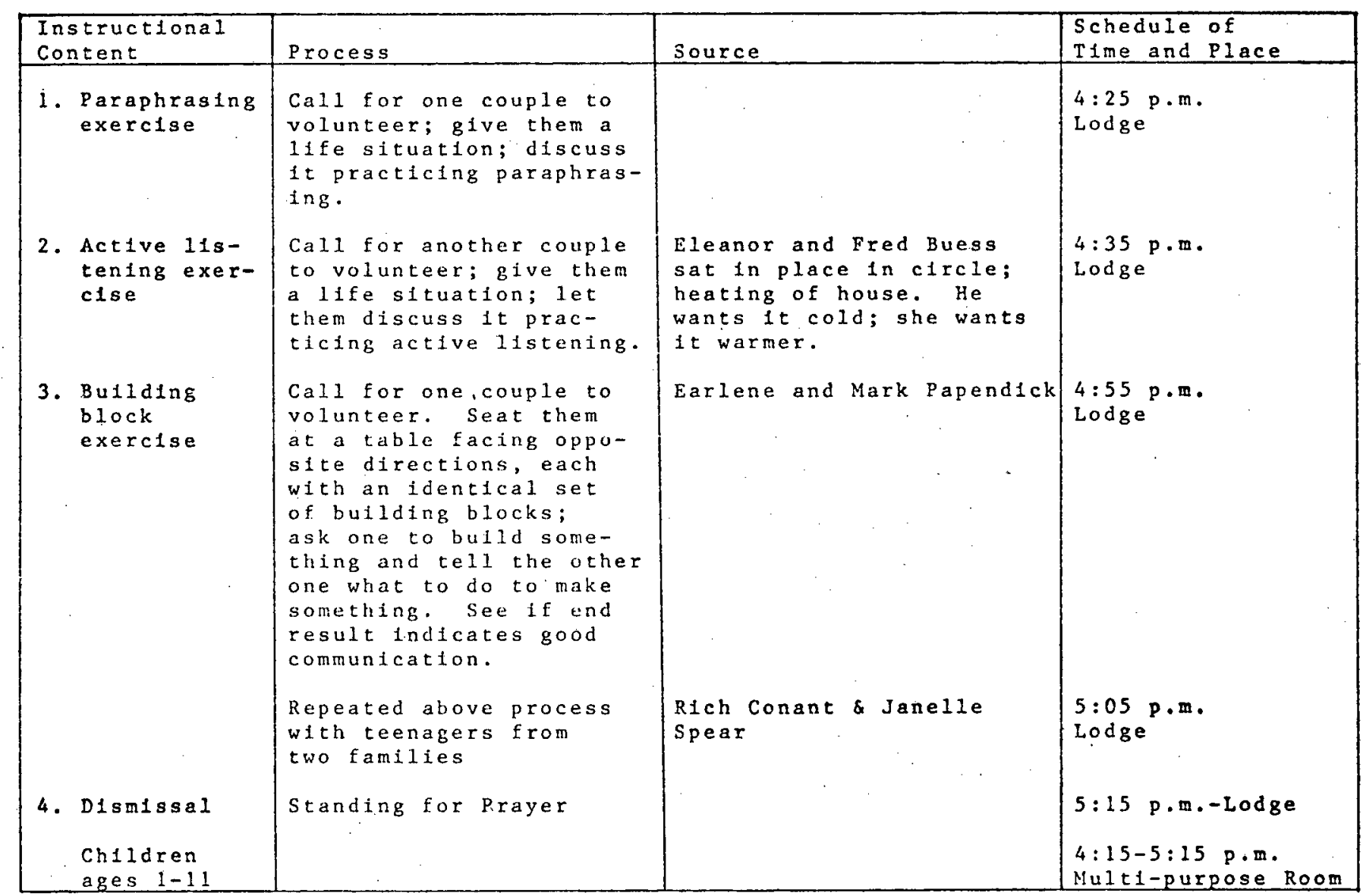


CHART XVI

EIGHTH SEMINAR SESSION, SATURDAY NIGHT, OCTOBER 11, 1975

Objectives:

1. To have fun together as a group of families.

2. To make participants increasingly aware of the importance of family recreation in building love relationships within the family.

\begin{tabular}{|c|c|c|c|}
\hline $\begin{array}{l}\text { Instructional } \\
\text { Content }\end{array}$ & Process & Sources & $\begin{array}{l}\text { Schedule of } \\
\text { Time and place }\end{array}$ \\
\hline $\begin{array}{l}\text { 1. Exercise In } \\
\text { family group } \\
\text { decision } \\
\text { making }\end{array}$ & $\begin{array}{l}\text { Divide into family groups } \\
\text { distribute N.A.S.A. group } \\
\text { decision game worksheets }\end{array}$ & $\begin{array}{l}\text { For N.A.S.A. group } \\
\text { decision game worksheet } \\
\text { see append } 1 \times \text { E }\end{array}$ & $\begin{array}{l}8: 10 \mathrm{p} \cdot \mathrm{m} \\
\text { Lodge }\end{array}$ \\
\hline $\begin{array}{l}\text { 2. Forced choice } \\
\text { value game }\end{array}$ & $\begin{array}{l}\text { Number off group } 1,2 ; \\
1,2 \text { etc. ask questions; } \\
\text { participants move to } \\
\text { one side or the other. }\end{array}$ & $\begin{array}{l}\text { See appendix E for sample } \\
\text { forced cholce value game } \\
\text { quiz sheet (not avallable) }\end{array}$ & $\begin{array}{l}8: 40 \\
\text { Lodge }\end{array}$ \\
\hline $\begin{array}{l}\text { 3. Group discus- } \\
\text { sion }\end{array}$ & $\begin{array}{l}\text { Elder cowan led discus- } \\
\text { ston about discipline } \\
\text { and communtcation. }\end{array}$ & $\begin{array}{l}\text { Adults only: teens and } \\
\text { junlors played volley- } \\
\text { ball outslde }\end{array}$ & $\begin{array}{l}8: 50 \mathrm{p} \cdot \mathrm{m} . \\
\text { Lodge }\end{array}$ \\
\hline $\begin{array}{l}\text { 4. Group discus- } \\
\text { sion }\end{array}$ & $\begin{array}{l}\text { Elder cowan led discus- } \\
\text { sion about communica- } \\
\text { tion and discipline. }\end{array}$ & $\begin{array}{l}\text { Teens and junfors only; } \\
\text { adults dismissed }\end{array}$ & $\begin{array}{l}9: 10 \mathrm{p} \cdot \mathrm{m} . \\
\text { Lodge }\end{array}$ \\
\hline $\begin{array}{l}\text { 5. Dismissal } \\
\text { of teens and } \\
\text { Junfors }\end{array}$ & & & $\begin{array}{l}9: 40 \text { p.m. } \\
\text { Lodge }\end{array}$ \\
\hline $\begin{array}{l}\text { Ch1ldren } \\
\text { ages l-11 }\end{array}$ & & & $\begin{array}{l}8: 00-9: 00 \text { p.m. } \\
\text { Mu1t1-purpose Room }\end{array}$ \\
\hline
\end{tabular}


CHART XVII

NINTH SEMINAR SESSION, SUNDAY, OCTOBER 12,1975

objectives:

1. To present the concept that true love for God and man will result

naturally in witnessing for Jesus Christ.

2. To present the concept that witnessing because you love people to

a life style, not simply one separate activity in the christian's $11 f e$.

\begin{tabular}{|c|c|c|c|}
\hline $\begin{array}{l}\text { Instructional } \\
\text { Content }\end{array}$ & Process & Sources & $\begin{array}{l}\text { Schedule } \\
\text { Time and place }\end{array}$ \\
\hline $\begin{array}{l}\text { 1. Presentation: } \\
\text { "Strategy for } \\
\text { W1tnessing" }\end{array}$ & $\begin{array}{l}\text { Elder Cowan presented } \\
\text { his sermon, "Witness } \\
\text { as a Life S,tyle", } \\
\text { while seated }\end{array}$ & $\begin{array}{l}\text { See appendix E for } \\
\text { sermon outline }\end{array}$ & $\begin{array}{l}9: 00 \text { a.m. } \\
\text { Lodge }\end{array}$ \\
\hline $\begin{array}{l}\text { 2. Large group } \\
\text { discusston }\end{array}$ & $\begin{array}{l}\text { Elder Cowan, discus- } \\
\text { sion leader; partici- } \\
\text { pants sharing ideas }\end{array}$ & Group interaction & $\begin{array}{l}9: 30 \text { a.m. } \\
\text { Lodge }\end{array}$ \\
\hline 3. Break & 10 minute recess & & $\begin{array}{l}\text { lo:30 a.m. } \\
\text { Lodge }\end{array}$ \\
\hline $\begin{array}{l}\text { Ch1ldren } \\
\text { ages } 1-11\end{array}$ & & & $\begin{array}{l}9: 00-10: 30 \text { a.m. } \\
\text { Mult1-purpose Room }\end{array}$ \\
\hline
\end{tabular}




\section{CHART XVIII}

TENTH SEMINAR SESSION, SUNDAY, OCTOBER 12, 1975

Objectives:

1. To allow opportunity for participants to structure some seminar time.

2. To permit participants to evaluate the seminar's effectiveness on paper.

\begin{tabular}{|c|c|c|c|}
\hline $\begin{array}{l}\text { Instructional } \\
\text { Content }\end{array}$ & Process & Sources & $\begin{array}{l}\text { Schedule of } \\
\text { Iime and Place }\end{array}$ \\
\hline $\begin{array}{l}\text { 1. Small group } \\
\text { discussion; } \\
\text { parents only }\end{array}$ & $\begin{array}{l}\text { Elder Cowan led } \\
\text { discussion on } \\
\text { communication and } \\
\text { areas of disci- } \\
\text { pline between } \\
\text { parents and } \\
\text { children }\end{array}$ & With parents only & $\begin{array}{l}10: 40 \mathrm{a} \cdot \mathrm{m} . \\
\text { Lodge }\end{array}$ \\
\hline $\begin{array}{l}\text { 2. Small group } \\
\text { discussion; } \\
\text { teenagers } \\
\text { only }\end{array}$ & $\begin{array}{l}\text { Elder Cowan led } \\
\text { discussion on } \\
\text { problems teen- } \\
\text { agexs have 1n } \\
\text { commintating. } \\
\text { with and relating } \\
\text { to their parents }\end{array}$ & With teenagers only & $\begin{array}{l}11: 10 \text { am. } \\
\text { Around fire pit } \\
\text { In Lodge }\end{array}$ \\
\hline 3: Evaluation & $\begin{array}{l}\text { Pass out } 5 \text { ques- } \\
\text { tion evaluation } \\
\text { sheet. Ask par- } \\
\text { ticipants to f } 111 \\
\text { out and pass them } \\
\text { back }\end{array}$ & $\begin{array}{l}\text { See appendix E for } \\
\text { evaluation form }\end{array}$ & $\begin{array}{l}11: 40 \cdot \mathrm{m} . \\
\operatorname{lodge}\end{array}$ \\
\hline $\begin{array}{l}\text { Ch11dren } \\
\text { ages } 1-11\end{array}$ & . & & $\begin{array}{l}10: 00-12: 00 \text { noon } \\
\text { Mu1t1-purpose Room }\end{array}$ \\
\hline
\end{tabular}




\section{The Data Reported}

The same type of data were gathered in both seminars; and the data for the second seminar will be reported in the same manner as were those for the first seminar.

\section{Evaluation Sheets}

The same evaluation sheets were used in both the Benton Harbor and Hemet seminars. A brief summary of the Hemet seminar evaluation sheets will be given here. ${ }^{1}$

In their answers to question one as to what was "the most helpful" in the seminar, one participant didn't know what was most helpful, one thought "every item [was] helpful," and several mentioned the specific various subject areas, such as communication, discipline, worship, witnessing, and love for God and others.

In addition, some people expressed their appreciation for the group processes of "interaction," "viewpoints of other people," and "sharing" as being the most helpful. One respondent said he (or she) "especially appreciated the isolated setting which added to the effectiveness of the program."

One person expressed concern about inflexibility in the format. Several thought the discussion with the teenagers was the "most helpful except we didn't have enough time."

In question two the participants were asked to share

${ }^{1}$ For a verbatim report, see appendix $E$. 
what was "least helpful" to them. The responses included the "recreational period," "the communicating games" which seemed to deal with unrealistic situations, the discussion on "solving children's problems since my children are older," "1istening to [a particular seminar participant] put in sometimes cynical, unrelated remarks," and the inability of one particpant "to get involved in" some of the discussions.

Under question three regarding suggestions for improving the seminar, the most common response was to have "more time" for the seminar. Other suggestions included "more use of audio-visual materials," "more family unit involvement," and "more time to be in small groups." Some also believed the seminar could be more on target if the group members could write down some questions or situations they would like to discuss.

Question four asked for comments participants would like to share. Most of the comments expressed appreciation for and enjoyment of various aspects of the seminar and several wished that more members of the church could have been involved. One person considered the seminar to be "a turning point in at least two learning situations" in his (her) 1 ife.

Question five, the one on overall evaluation, was answered by fourteen people as "excellent," four as "good," one as "poor," and one had no response to this question. Twenty people turned in evaluation sheets. 


\section{The Family Surveys}

While twenty-two participants responded by completing the pretest survey, only eleven respondents were recorded for the postest. While this represents only a 50 percent response, some selected data will still be reported here as they were analyzed by a computer. Since al1 of the participants stayed for the whole weekend, no separation was needed between high and low frequency attendance.

The biographical data revealed that slightly over half of the participants werefemales; the age of the respondents ranged from 12 to "61 and over" years; the occupational spread ranged from "professional" to "other," with the highest two categories indicating they were either "professionals" or "students" (31.8\% in both instances); over half of the group were "married once-still living with that spouse; and most of these had been married from "20 to 29" years; 90 percent were Seventh-day Adventists and had been members of the church for from "21 to 40 years"; a11 who answered the questions ( $59.1 \%)$ indicated their spouses were SDAs and most of them had been for from "21 to 40 years"; over one-fourth of the group had not finished high school, and one person had not finished elementary school; and most of the spouses were reported to have some college or higher training.

The only observed changes that are reported here are those that showed an increase in the percentage of the 
total number of people responding to any one answer at $13.7 \%$ or more. However, one case of less than $13.7 \%$ of change is noted where the percentage of the total in the posttest is double that of the pretest. These responses are reported in the following statistical table. They will be interpreted in chapter VI.

TABLE II

Observed Change from Pretests to Postests

\begin{tabular}{|c|c|c|c|c|c|c|}
\hline \multirow{2}{*}{$\begin{array}{l}\text { Question } \\
\text { Answer }\end{array}$} & \multirow{2}{*}{$\begin{array}{l}\text { Subject } \\
\text { Category }\end{array}$} & \multicolumn{2}{|c|}{ Pretest } & \multicolumn{2}{|c|}{ Posttest } & \multirow{2}{*}{$\begin{array}{l}\text { Change In } \\
\% \text { of Total }\end{array}$} \\
\hline & & No. & $\%$ & No. & $\%$ & \\
\hline $22: 1$ & $\begin{array}{l}\text { Pers. devotions, } \\
\text { enjoyment }\end{array}$ & 15 & 68 & 9 & 81.8 & 13.8 \\
\hline $23: 1$ & $\begin{array}{l}\text { Pers. devotions, } \\
\text { eagerness }\end{array}$ & 10 & 45.5 & 7 & 63.6 & 18.1 \\
\hline $25: 4$ & $\begin{array}{l}\text { Prayer-- } \\
\text { anywhere }\end{array}$ & 17 & 77.3 & 11 & 100.0 & 22.7 \\
\hline 31.5 & $\begin{array}{l}\text { Belief in love } \\
\text { for Jesus }\end{array}$ & 17 & 77.3 & 11 & 100.0 & 22.7 \\
\hline 34.2 & $\begin{array}{l}\text { Condition of } \\
\text { marriage }\end{array}$ & 5 & 22.7 & 5 & 45.5 & 22.8 \\
\hline 40.2 & $\begin{array}{l}\text { Spouse, leisure } \\
\text { time }\end{array}$ & 7 & 31.8 & 5 & 45.5 & 13.7 \\
\hline 42.2 & $\begin{array}{l}\text { Leisure time, } \\
\text { self }\end{array}$ & 1 & 4.5 & 1. & 9.1 & 4.6 \\
\hline 60.3 & $\begin{array}{l}\text { Witness a } \\
\text { lifestyle }\end{array}$ & 5 & 22.7 & 6 & 54.5 & 31.8 \\
\hline 61.2 & $\begin{array}{l}\text { Reason for } \\
\text { witness }\end{array}$ & 8 & 36.4 & 6 & 54.5 & 18.1 \\
\hline 62.2 & $\begin{array}{l}\text { Witness to } \\
\text { neighbors }\end{array}$ & 16 & 72.7 & 1 & 90.9 & 18.2 \\
\hline
\end{tabular}


CHAPTER VI

\section{SUMMARY, EVALUATION, AND RECOMMENDATIONS}

\section{Summary}

In chapter I it was admitted that relationship problems do exist in Adventist families. While societal pressures in the modern American culture have contributed to these problems, it was suggested that the underlying cause was an inadequacy on the part of Adventists in their love relationships with God.. Therefore, the overall goal of this seminar was to help families in the development of love for both God and man. It was suggested that the church has a responsibility to help families in the development of this love. The terms used in this paper were clarified and the research design for this project was outlined. Chapter II provided a select survey of the literature in the field of family enrichment. The sources referred to in that chapter were selected from the subject areas of premarital preparation, marriage enrichment, marriage counseling, child development and training, and family enrichment. In addition, the limitations of the current literature were identified and the distinctive features of this seminar were pointed out.

In chapter III love was identified as the central 


\section{8}

issue in the context of the home as the school of love. Love was found to be a part of the image of God in man which was marred by man's fall into sin and which is to be restored by the plan of redemption. It was also suggested that the best place for people to develop love is the home. The fourth chapter reported the planning and conducting of the writer's first seminar which was held in the Benton Harbor, Michigan, Adventist church from November 16-23, 1974. The outline of each meeting was given in chart form. The data from the evaluation sheets and family survey questionnaires that were used were reported.

Chapter $V$ was similar in style to chapter IV except that jt reported on the Hemet, California, Adventist church family seminar held at Pine Springs Ranch, October 10-12, 1975. The outlines for each session were given in chart form and the evaluation data for that seminar were reported: Some changes were made in the second seminar because of the lessons learned in the first seminar. In addition, the weekend format was shown in comparison with the one week format presented in chapter IV.

\section{Evaluation}

There were two instruments for evaluation used at each seminar (the evaluation sheets and the family surveys) in an attempt to ascertain the value of the seminar to those who participated. The evaluation sheets were subjective while the family surveys were objective in design. In 
addition, the seminar leader evaluated himself as to his personal learning goals. These three types of evaluations will. be presented in this chapter after a few observations about the evaluation process in general on this kind of seminar. Robert 0. Blood points out that it isn't easy to accurately measure attitudinal changes, like the development of love that was attempted in this seminar.

. Things like love, unselfishness, problem-
solving ability, and personal maturity are not as
easily measured as skin color and employment status.
Yet in many ways these soft variables deal with
those ways of relating to one another which are the
essence of family living. These are the things
which I spend most of my time as a marriage coun-
selor and workshop facilitator helping people achieve.
I have a lot of faith that what I am doing is useful,
but I would like to have that faith put to the test
of scientific research.l

It is the writer's opinion that the evaluation sheets have provided a more reliable assessment of these two seminars than the family survey, partly because this family survey is so new and partly because so few completed questionnaires are presently available for analysis. Hence the evaluation sheets will be discussed first.

\section{Evaluation Sheets}

The participants of the two seminars reported enjoying the practicality, informality, openness, and sharing within the small group as the most helpful things that

${ }^{1}$ Robert 0 . Blood, "Research Needs of a Family Life Educator and Marriage Counselor," Journal of Marriage and the Family 38 (February 1976): 10 . 
happened in the seminars, according to the sixty-six evaluation sheets which were returned.

The most common report of the least helpful happening was the block on witnessing in the first seminar and the communication games in the second seminar. Because of this information, the witnessing block was changed in the second seminar to more closely fit in with the overall seminar format. The writer's opinion is that the reported communication games that were seen as least helpful were the communication role-plays rather than the building blocks game. It is anticipated that by giving people the opportunity to communicate on their own areas of real problems this aspect of the seminar will be strengthened in the future.

The most common suggestion for improvement in both seminars was to have more time. It was variously suggested that more evenings close together could be devoted to the seminar, that the meetings could be spread out over a longer time period, or that longer time periods could be held for each session.

Participants in both seminars suggested that some kind of follow-up meetings be held and that the opportunity to attend a seminar be extended to other church members also. The majority of the participants of both seminars rated the seminar as "excellent" overall, a few rated it as "good," none as "fair," and only one as "poor," with two leaving this question blank. 
the seminar was generally considered helpful to and appreciated by the participants.

\section{The Family Surveys}

of the 75 pretest surveys that were returned, 53 were from Benton Harbor and 22 were from Hemet. Of the 64 posttest surveys, 53 were from Benton Harbor and 11 from Hemet. Any interpretation of the data from the family surveys must be considered tentative because of the small amount of data gathered. Since no statistical method for calculating the significance level was employed, these data merely state that a certain percentage level is observed to be higher than another percentage level. There is no conclusion based exclusively on this difference since the observed change may have been by chance or it may have been as a result of the treatment.

The first possible interpretation that can be drawn from the surveys in both tables 1 and 2 is that more answer categories were observed as changed with high-frequency attendance than with low-frequency attendance. This possible interpretation is based on the observation that only two categories of observed change occurred in the low-frequency attendance group as compared to eighteen categories of answer change in the high-frequency attendance groups. The data therefore suggest the possibility that a greater exposure to the concepts of the seminar is more likely to lead to observed changes in the beliefs and attitudes of the 
participants than would be expected otherwise.

The second possible interpretation is that the on $1 y$ observed change in percentage reduction (table 1, question 20, answer 1) is interpreted as a positive response. This possible interpretation is based on the concept that a lowered percentage on this question reveals a change from having no private devotions to having some private devotions. These data reveal a lowering of the percentage of people having no private devotions from $37.7 \%$ to $17.7 \%$. This was therefore considered to be a positive change even though the data reported it as a reduced percentage shift. The third possible interpretation is based on the observation that there were only five of a possible fiftythree subject categories (beyond the biographical information) which showed a change in both seminars. These five subject categories showed (1) an increase of enjoyment in personal devotions, (2) an increase of eagerness to have personal devotions, (3) an increase in belief that Christianity means love for Jesus, (4) an increase in belief that witness is a life style, and (5) an increase in belief that love is the motivating force in witnessing. One possible interpretation that is suggested by this information is that the seminars may have been strongest in the presentations on (1) the personal devotional life, (2) the love for Jesus as one of the basic issues in Christianity, and (3) witnessing as a life style, motivated by love. 
Another possible alternate interpretation on this point could be that the need in the participants was more keenly felt for change in these five areas, rather than that the seminar presentations were stronger in these areas .

The last possible interpretation from the survey data is that the twenty observed changes in attitudes and beliefs that were recorded may have been part $1 \mathrm{y}$ due to the influence of the seminars. This possible interpretation therefore allows for other influences in the participants' lives during the time period between the pretests and the postests.

Seminar Leader's Self-evaluation

Before the first seminar was conducted, the leader had suggested eight possible learning goals from this project: six for himself and two for the church. These goals will be stated here and commented upon separately.

\section{Learning goals for the leader}

Learning goals for the leader are:

1. To develop greater personal competency as the spiritual leader in his own nuclear family and in his extended family.

The leader believes himself to be more competent now as a family spiritual leader. The confidence gained in developing and leading in these two seminars is partly responsible for his belief that he now has greater 
competency in family-life situations.

2. To develop greater personal competency in meeting the challenge of improving the spiritual life of the families in churches where he will serve as a pastor in the future.

The leader believes his competency to help church families grow spiritually has improved significantly because of the greater background of knowledge and experience he now has from his involvement in this seminar project.

3. To develop greater competency in preaching sabbath morning sermons to congregations on the theme of the Christian home.

The leader believes this goal too has been achieved. Two sermons on the home were preached in Benton Harbor in conjunction with the first seminar. In addition, the background of study given to the home in connection with this project has given added depth to the leader's preaching reservoir on the subject of the home.

4. To acquire the necessary skills for fulfilling a need in the church, which is intuitively perceived while functioning as a pastor, once that need is identified.

This goal has been achieved in at least one area (the home) and the leader believes that many of the skills and principles utilized in fulfilling one perceived need are transferrable to other future needs.

5. To develop the skills requisite to designing a 
seminar or workshop to fulfill a church need.

The leader believes he has also accomplished this goal as is evidenced by the seminar he has designed, called "Home, the School of Love."

6. To develop the skills needed to conduct or lead out in a seminar for adult education which would create a high degree of motivation, interest, and participation in the adults being trained.

This goal too has been achieved. The one part of the seminar in which the participants showed the lowest degree of motivation, interest, and participation was the filling out of the family surveys for the pretest and the posttest. It was difficult to get these questionnaires returned in their completed form. Some participants expressed to the leader that it was very hard to make decisions about which option should be selected in answer to each question. This deterrant to interest could be removed by conducting a seminar without the pretest and posttest questionnaires.

Learning goals for the church members

The goals for the church-member participants are:

1. For a small group of families to experience spiritual growth during the one week (or weekend) seminar. This goal was accomplished at each seminar.

2. For the involved families to gain insight and motivation during the seminar which can be applied and 
carried over to the other fifty-one weeks of the year for family enrichment.

This goal has not been tested. However, informal feedback from some seminar participants since the seminars has indicated they want some help in accomplishing this goal by follow-up meetings of some kind.

\section{Recommendations}

The following eight recommendations suggested here are based on this project as reported in the foregoing pages. Whereas the participants in both the Benton Harbor and Hemet seminars expressed their appreciation for the family spiritual enrichment seminar content, format, and smal1-group process as a help in fulfilling some important needs with Seventh-day Adventist families, it is recommended that:

1. The leader conduct at least one family spiritual enrichment seminar annualy in his local church.

2. The leader follow up each seminar with a monthly (or quarterly) meeting for seminar alumni.

3. The leader utilize the materials and concepts in premarital and marital counseling as often as possible.

4. The leader make himself available for a maximum of one seminar a year away from his local church if the need arises.

5. An experiment be done in using this format for a series of evangelistic meetings to win families to christ 
who are not now Seventh-day Adventists.

6. An on-going family study group be established in the leader's church, that the group meet every two weeks, and that the seminar materials used for this project form the basis for this study group.

7. These materials be made available, possibly through one of the Adventist denomination publishing companies, as a seminar syllabus for other pastors, a book, or a Sabbath School lesson quarterly. so that a wider group in the Adventist church could use them.

8. The leader continue to study and refine the principles and procedures on how to develop love for God and man in families as a specialization in his future ministry, with the goal of helping to prepare a people to meet their Lord.

Richard Niebuhr and Daniel Williams once wrote: "No subsitute can be found for the definition of the goal of the church as the increase among men of the love of God and neighbor. "1

This writer agrees. It has been his goal in this project to promote among seminar participants the development of a deep and abiding love by people for God, love within families, and love for all other human beings outside of one's own family. To the extent that some people

$1_{\text {H. Richard Niebuhr and Daniel Day Williams, The }}$ Purpose of the Church and Its Ministry (New York: Harper \& Brothers, 1956), p. 32. 
may grow in their love relationships on all three of these levels partly as a result of these family spiritual enrichment seminars will this project have proven itself to be of lasting value. 
APPENDICES 
APPENDIX A

ADDITIONAL ELLEN G. WHITE QUOTATIONS ON THE RESTORATION OF THE IMAGE OF GOD IN MAN 


\author{
ADDITIONAL ELLEN G. WHITE QUOTATIONS ON THE
}

\author{
RESTORATION OF THE IMAGE OF GOD IN MAN
}

\begin{abstract}
"Man, who has defaced the image of God in his soul by a corrupt 11fe, cannot, by mere human effort, effect a radical change in himself. He must accept the provisions of the gospel; he must be reconciled to God through obedience to His law and faith in Jesus Christ. His life from henceforth must be governed by a new principle. Through repentance, faith, and good works he may perfect a righteous character, and claim, through the merits of Christ the privileges of the sons of God. The principles of divine truth, received and cherished in the heart, will carry us to a height of moral excellence that we had not deemed it possible for us to reach. 'And it doth not yet appear what we shall be; but we know that when He shall appear, we shall be like Him; for we shall see Him as $\mathrm{He}$ is. And every man that hath this hope in Him purifieth himself, even as He is pure."' Testimonies For the Church, vol. 4, p. 294 .
\end{abstract}

"By sin the image of God in man has been marred and well-nigh obliterated; it is the work of the gospel to restore that which has been lost; and we are to cooperate with the divine agency in this work." Testimonies For the Church, vol. 5, p. 743.

"Satan was exulting that he had succeeded in debasing the image of God in humanity. Then [when the fullness of the time was come, Gal. 4:4] Jesus came to restore in man the image of his maker. None but Christ can fashion anew the character that has been ruined by sin." The Desire of Ages, pp. 37-38.

"This is the crisis of the world. If I become the propitiation for the sins of men, the world will be lighted up. Satan's hold upon the souls of men will be broken. The defaced image of God will be restored in humanity, and a family of believing saints will finally inherit the heavenly home. This is the result of Christ's death. The Saviour is lost in contemplation of the scene of triumph called up before Him. He sees the cross, the cruel, ignominious cross, with all its attending horrors, blazing with glory." The Desire of Ages, p. 625.

"By looking constantly to Jesus with the eye of faith, we shall be strengthened. God will make the most precious revelations to His hungering, thirsting people. They will find that Christ is a personal Saviour. As they feed upon His word, they find that it is spirit and iffe in Christ Jesus. The Holy Spirit comes to the soul as a comforter. By the transforming agency of His grace, the image of God is reproduced in the disciple; he becomes a new creature. Love takes the place of hatred, and the heart receives the divine similitude. This is what it means to live 'by every word that proceedeth out of the mouth of God.' Thls is eating the Bread that comes down from heaven." The Desire of Ages, p. 391. 


\section{2}

"The education to be secured by searching the Scriptures is an experimental knowledge of the plan of salvation. Such an education will restore the image of God in the soul." Christ's Object Lessons, pp. 42-43.

"Thus God showed His love for man. With Christ He gave all heaven, that the moral image of God might be restored in man. . . His grace in all its vastness is provided for all." Sons and Daughters of God, p. 11.

"The knowledge of God as revealed in Christ is the knowledge that all who are saved must have. It is the knowledge that works transformation of character. This knowledge received, will re-create the soul in the image of God. It will impart to the whole being a spiritual power that is divine." Testimonies For the Church, vol 8, p. 289.

"Sin has marred the divine image in man. Through Christ this may be restored, but it is only through earnest prayer and the conquest of self that we can become partakers of the divine nature. . . ." Testimonies to Ministers and Gospel Workers, p. 80.

"The lost coin in the Saviour's parable though lying in the dirt and rubbish, was a piece of silver still. Its owner sought it because it was of value. So every soul, however degraded by sin, is in God's sight accounted precious. As the coin bore the image and superscription of the reigning power, so man at his creation bore the image and superscription of God. Though now marred and dim through tine influence of sin, the traces of this inscription remain upon every soul. God desires to recover that soul and to retrace upon it His own image in righteousness and holiness." The Ministry of Healing, p. 163.

"The teachers [in Christian schools] need to be sanctified through the truth, and the all-important thing should be the conversion of their students, that they may have a new heart and life. The object of the Great Teacher is the restoration of the image of God in the soul, and every teacher in our schools should work in harmony with this purpose." Fundamentals of Christian Education, p. 436.

"God's love for His children during the period of their severest trial [the time of trouble] is as strong and tender as in the days of their sunniest prosperity; but it is needful for them to be placed in the furnace of fire; their earthliness must be consumed, that the image of Christ may be perfectly reflected." The Great Controversy, p. 621. 
APPENDIX B

ADDITIONAL ELLEN G. WHITE QUOTATIONS ON LOVE 
ADDITIONAL ELLEN G. WHITE QUOTATIONS ON LOVE

"The whole work of grace is one continual service of love, of self-denying, self-sacrificing effort. During every hour of Christ's sojourn upon the earth, the love of God was flowing from Him in irrepressible streams. All who are inbued with His Spirit will love as He loved. The very principle that actuated Christ will activate them in all their dealing one with another." The Desire of Ages, pp. 677-678.

"The exercise of force is contrary to the principles of God's government; He desires only the service of love; and love cannot be commanded; it cannot be won by force or authority. only by love is love awakened. To know God is to love Him; His character must be manifested in contrast to the character of Satan. This work only one Being in all the universe could do. Only He who knew the height and depth of the love of God could make it known. Upon the world's dark night the Sun of Righteousness must rise, 'with healing in His wings.' Ma1 4:2."

(Italics mine.) The Desire of Ages, p. 22.

". . it is loving service, true humility, which constitutes real greatness. How was He to kindle love. . ? [He washed their feet.] So Christ expressed His love for His disciples." (Italics mine.) The Desire of Ages, p. 644 .

"We are not to make less prominent the special truths that have separated us from the world, and made us what we are; for they are fraught with eternal interests. . But it is the life of Christ in the soul, it is the active principle of love imparted by the Holy Spirit, that alone will make our words fruitful. The love of Christ is the force and power of every message for God that ever fell from human lips." Testimonies To Ministers and Gospel Workers, p. 288.

"One of the strongest evidences of true conversion is love to God and man. Those who accept Jesus as their Redeemer have a deep, sincere love for others of like precious faith." The Acts of the Apostles, p. 262 .

"True refinement will never be revealed so long as self is oonsidered as the supreme object. Love must dwell in the heart. A thoroughgoing Christian draws his motives of action from his deep heart-love for his Master. Up through the roots of his affection for Christ springs an unselfish interest in his brethren. Love imparts to its possessor grace, propriety, and comeliness of deportment. It illuminates the countenance and subdues the voice; it refines and elevates the whole being." (Italics mine.) The Ministry of Healing, p. 490.

"Love must be the principle of action in the Christian life. Love is the underlying principle of God's government in heaven and earth, and it must be the foundation of the Christian's character. This alone can make and keep him steadfast. This alone can enable him to withstand trial and temptation. 
"And love will be revealed in sacrifice. The plan of redemption was laid in sacrifice, - -a sacrifice so broad and deep and high that it is immeasurable. Christ gave all for us, and those who receive Christ will be ready to sacrifice all for the sake of their Redeemer. The thought of His honor and glory will come before anything else.

"If we love Jesus, we shall love to live for Him, to present our thank offerings to Him, to labor for Him. Then every labor will be 1ight. For his sake we shall covet pain and toil and sacrifice. We shall sympathize with His longing for the savlation of men. We shall feel the same tender craving for souls that He has felt.

"This is the religion of Christ. Anything short of it is a deception. No mere theory of truth or profession of discipleship will save any soul. We do not belong to Christ unless we are $H$ is wholly. It is by half-heartedness in the Christian life that men become feeble in purpose and changeable in desire. The effort to serve both self and Christ makes one a stony-ground hearer, and he will not endure when the test comes upon him." (Italics mine.) Christ's Object Lessons, pp. 49-50.

"The great motive powers of the soul are faith, hope and love; and $i t$ is to these that Bible study, rightly pursued, appeals. . . . As the student of the Bible beholds the Redeemer, there is awakened in the soul the mysterious power of faith, adoration, and love. Upon the vision of Christ the gaze is fixed, and the beholder grows into the likeness of that which he adores." (Italics mine.) Education, p. 192.

"The attribute that Christ appreciates most in man is charity (love) out of a pure heart. This is the fruit borne upon the christian tree (MS 16, 1892)." Seventh-day Adventist Bible Commentary, vo1. 6, p. 1091 .

"Said Christ, 'Love one another, as I have loved you;' not with a greater love; for 'greater love hath no man than this, that a man lay down his life for his friends.' Our love is frequently selfish, for we confine it to prescribed limits. When we come into close union and fellowship with Christ, our love and sympathy and our works of benevolence will reach down deeper and will widen and strengthen with exercise. The love and interest of Christ's followers must be as broad as the world. Those who live merely for 'me and mine' will fail of heaven. God calls upon you as a family to cultivate love, to become less sensitive in regard to yourselves and more sensitive to the griefs and trials of others. This selfish spirit that you have cherished all your lives is correctly represented by the priest and the Levite who passed by the unfortunate on the other side. They said that he needed help, but purposely avoided him." The Acts of the Apostles, Pp. 529-530.

"The light shining from the cross reveals the love of God. His love is drawing us to Himself. If we do not resist this drawing, we shall be led to the foot of the cross in repentance for the sins that have crucified the Saviour. Then the Spirit of God through faith produces new life in the soul." The Desire of Ages, p. 176.

"Men cannot love God supremely and their neighbor as themselves, and be as cold as icebergs. Not only do they rob God of the love due 
Him, but they rob their neighbor as well. Love is a plant of heavenly growth, and it must be fostered and nourished. Affectionate hearts, truthful loving words, will make happy families and exert an elevating Influence upon all who come within the sphere of their influence.

"Those who make the most of their privileges and opportunities will be, in the Bible sense, talented and educated men; not learned merely, but educated, in mind, in manners, in deportment. They will be refined, tender, pitiful, affectionate." (Italics mine.) Testimonies For the Church, vol. 4, p. 548.

"Paul set forth the importance of that love which should be cherished by the followers of Christ: . . . [1 Cor. 13:1-3 is quoted here.]

"No matter how high the profession, he whose heart is not filled with love for God and his fellow man is not a true disciple of Christ. Though he should possess great faith and have power even to work miracles, yet without love his faith would be worthless. He might display great liberality; but should he, from some other motive than genuine love, bestow all his goods to feed the poor, the act. would not commend him to the favor of God. In his zeal he might even meet a martyr's death, yet if not actuated by love, he would be regarded by God as a deluded enthusiast or an ambitious hypocrite.

"(1 Cor. 13:5) Christlike love places the most favorable construction on the motives and acts of others. It does not needlessiy expose their faults; it does not listen eagerly to unfavorable reports, but seeks rather to bring to mind the good qualities of others. . .

"This love 'never faileth.' It can never lose its value; it is a heavenly attribute. As a precious treasure, it will be carried by its possessor through the portals of the city of God." The Acts of the Apostles, pp. 318-319.

"The question that Christ put to Peter was significant. He mentioned only one condition of discipleship and service. 'Lovest thou Me?' He said. This is the essential qualification. Though Peter might possess every other, without the love of Christ he could not be a faithful shepherd over the Lord's flock. Knowledge, benevolence, eloquence, gratitude, and zeal are all aids in the good work; but without the love of Jesus in the heart, the work of the Christian minister will prove a failure." Testimonies to Ministers and Gospel Workers, p. 183.

"The Lord desires me to call the attention of His people to the thirteenth chapter of First Corinthians. Read this chapter every day, and from it obtain comfort and strength. Learn from it the value that God places on sanctified, heaven-born love, and let the lesson that it teaches come home to your hearts. Learn that Christlike love is of heavenly birth, and that without it all other qualifications are worthless. (RH July 21, 1904)." Seventh-day Adventist Bible Commentary, vol. 6, p. 1061 .

"All the paternal love which has come down from generation to generation through the channel of human hearts, all the springs of tenderness which have opened in the souls of men, are but as a tiny rill to the boundless ocean when compared with the infinite, exhaustless love of God. Tongue cannot utter it; pen cannot portray it. You may 
meditate upon it every day of your life; you may search the Scriptures diligently in order to understand it; you may summon every power and capability that God has given you, in the endeavor to comprehend the love and compassion of the heavenly Father; and yet there is an infinity beyond. You may study that love for ages; yet you can never fully comprehend the length and the breadth, the depth and the height, of the love of God in giving His Son to die for the world. Eternity itself can never fully reveal it. Yet as we study the Bible and meditate upon the life of Christ and the plan of redemption, these great themes will open to our understanding more and more." Testimonies For the Church, vol. 5, p. 740 . 


\section{APPENDIX C}

ADDITIONAL ELLEN G. WHITE QUOTATIONS ON THE IMPORTANCE OF THE HOME AS A TRAINING

SCHOOL FOR LOVE 


\title{
ADDITIONAL ELLEN G. WHITE QUOTATIONS ON THE IMPORTANCE OF THE HOME AS A TRAINING \\ SCHOOL FOR LOVE
}

\begin{abstract}
"Neither the husband nor the wife should merge his or her individuality in that of the other. Each has a personal relation to God. Of Him each is to ask, 'What is right?' 'What is wrong?' 'How may I best fulfill life's purpose?' Let the wealth of your affection flow forth to Him who gave His life for you. Make Christ first and last and best in everything. As your love for Him becomes deeper and stronger, your love for each other will be purified and strengthened." Ministry of Healing, p. 361.
\end{abstract}

"The unstudied, unconscious influence of the holy life is the most convincing sermon that can be given in favor of Christianity. Argument, even when unanswerable, may provoke only opposition; but a godly example has a power that it is impossible wholly to resist." Testimonies to Ministers and Gospel Workers, p. 59.

"The more closely the members of a family are united in their work in the home, the more uplifting and helpful will be the influence that father and mother and sons and daughters will exert outside the home." The Adventist Home, p. 37.

"In the story of the good Samaritan, Jesus gave a picture of Himself and His mission. . . (Jn 15:17; 13:34)

"The Samaritan had obeyed the dictates of a kind and loving heart, and in this had proved himself a doer of the law. . .

"The lesson is no less needed in the world today than when it fell from the lips of Jesus. Selfishness and cold formality have wellnigh extinguished the fire of love, and dispelled the graces that should make fragrant the character. Many who profess His name have lost sight of the fact that Christians are to represent Christ. Unless there is practical self-sacrifice for the good of others, in the family circle, in the neighborhood, in the church, and wherever we may be, then whatever our profession, we are not Christians. . . .

"The love of God in the heart is the only spring of love toward our neighbors." (1 Jn 4:20-21) The Desire of Ages, pp. 503-505.

"After the birth of his first son, he (Enoch) reached a higher experience; he was drawn into closer relationship with God. As he saw the child's love for its father, its simple trust in his protection; as he felt the deep yearning tenderness of his own heart for that firstborn son, he learned a precious lesson of the wonderful love of God to man in the gift of His Son, and the confidence which the children of God may repose in their heavenly Father. The infinite, unfathonable love of God through Christ, became the subject of his meditations day and night. With all the fervor of his soul he sought to reveal that love to the people among whom he dwelt." Testimonies to Ministers and Gospel Workers, p. 51 . 
"John (the revelator) saw the mercy, the tenderness, and the love of God blending with His holiness, justice, and power. . . .

"The Saviour is presented before John under the symbols of 'the Lion of the tribe of Judah' and of 'a Lamb as it had been slain' Revelation 5:5,6. These symbols represent the union of omnipotent power and self-sacrificing love. The Lion of Judah, so terrible to the rejecters of His grace, will be the Lamb of God to the obedient and faithful." The Acts of the Apostles, p. 589.

"Bro. M. has made a mistake in his domestic 1ife. He has not, in words, expressed that affection for his wife that it was his duty to express. . . The best way for Bro. M. to be a living missionary in his family, is for him to exemplify in his life the life of our dear Redeemer." Testimonies. For the Church, vo1. 2, pp. 676-677.

"There is need for constant watching that the principles which lie at the foundation of family government are not disregarded. The Lord designs that the families on earth shall be symbols of the family in heaven. . ..

"Parents should themselves be converted.. . before they can rightly represent the government that God designed should exist in the family.

"God Himself established the family relations. His word is the only safe guide in the management of children. Human philosophy has not discovered more than God knows or devised a wiser plan of dealing with children than that given by our Lord. . . . If the word of God were carefully studied and faithfully obeyed, there would be less soul anguish over the perverse conduct of wicked children." (Italics mine.) The Adventist Home, p. 306.

"The sweetest type of heaven is a home where the Spirit of the Lord is present." The Adventist Home, p. 15.

"Christ abiding in the heart of the wife will be at agreement. with Christ abiding in the heart of the husband." The Adventist Home, p. 120 .

own families. . . .

"L needs to cultivate love for his wife, love that will find expression in words and deeds. . . His unsympathizing nature needs to be brought into close contact with Christ, that the stiffness and cold reserve may be subdued and softened by divine love. It will not be weakness or a sacrifice of manhood and dignity to give his wife expressions of tenderness and sympathy in words and acts; and let it not end with the family circle, but extend to those outside the family. . . . His affection and love should be centered upon Christ and heavenly things, and he should be forming a character for everlasting life." (Italics mine.) Testimonies For the Church, vol. 3, pp. 529-531.

"The Sabbath and the family were alike instituted in Eden, and In God's purpose they are indissolubly Innked together. On this day more than on any other, it is possible for us to live the life of Eden. It 
It was God's plan for the members of the family to be associated in work and study, in worship and recreation, the father as priest of his household, and both father and mother as teachers and companions of their children. - . In His own day He preserves for the family opportunity for communion with Him, with nature, and with one another." Education, pp. 250-251.

"Perfect confidence should exist between husband and wife. Together they should work for the highest good of their children. Never should they in the presence of the children criticize each other's plans or question each other's judgment. Let the wife be careful not to make the husband's work for the children more difficult. Let the husband hold up the hands of the wife, giving her wise counsel and loving encouragement." The Ministry of Healing, pp. 393-394. 
APPENDIX D

ADDITIONAL ELLEN G. WHITE QUOTATIONS ON THE IMPORTAINCE OF THE HOME FROM THE BOOK

THE ADVENTIST HOME 


\section{ADDITIONAL ELLEN G. WHITE QUOTATIONS ON THE IMPORTANCE OF THE HOME FROM THE BOOK \\ THE ADVEINTIST HOME}

". - The well-being of society, the success of the church, the prosperity of the nation, depend upon home influences." p. 15.

"Home should be made all that the word implies. It should be a little heaven upon earth, a place where the affections are cultivated instead of being studiously repressed. Our happiness depends upon this cultivation of love, sympathy, and true courtesy to one another." p. 15. "The family ti
any on earth." p. 18 .

"The home should be to the children the most attractive place in the world, and the mother's presence should be its greatest attraction. Children have sensitive, loving natures. They are easily pleased, and easily made unhappy. By gentle discipline, in loving words and acts, mothers may bind their children to their hearts.". p. 21 .

"The sphere of the mother may be humble but her influence, united with the father's is as abiding as eternity. Next to God, the mother's power for good is the strongest known on earth." p. 240 .

"One well-ordered, well-disciplined family tells more in behalf of Christianity than all the sermons that can be preached." p. 32 .

". - The world is not so much in need of great minds as of good men who will be a blessing to their homes." p. 38 .

"Love is a plant of heavenly growth, and it must be fostered and nourished. Affectionate hearts, truthful, loving words, will make happy families and exert an elevating influence upon a11 who come within the sphere of their influence." p. 50.

"There is not one family in a hundred who will be improved physically, mentally, or spiritually by residing in the city. Faith, hope, love, happiness, can far better be gained in retired places, where there are fields and hills and trees. Take your children away from the sights and sounds of the city. . ." p. 137

"Four walls and costly furniture, velvet carpets, elegant mirrors, and fine pictures do not make a 'home' if sympathy and love are wanting." p. 155 .

"The minister's duties lie around him, nigh and afar off; but his first duty is to his children. . . Nothing can excuse the minister for neglecting the inner circle for the larger circle outside. The spiritual welfare of his family comes first." p. 353. 


\section{4}

"The very best legacy which parents can leave their children is a knowledge of useful labor and the example of a life characterized by disinterested benevolence. By such a life they show the true value of money, that it is only to be appreciated for the good that it will accomplish in relieving their own wants and the necessities of others, and in advancing the cause of God." p. 390. 
APPENDIX E

SOME SAMPLES OF THE MATERIALS USED IN CONDUCTING FAMILY SPIRITUAI

ENRICHMENT SEMINARS 
"Home: the School of Love"

A Seminar in Family Spiritual Enrichment

FANILY SURVEY .

INSTRUCTIONS TO THE RESFONDENT: Flease select only one answer under each numerical category. Indicate your choice by placing a check mark in the box in front of that answer. It is important to answer every question. In each case please check the REAL, not the IDEAL. Unmarried children need on].y answer those categories marked by an asterisk (*). Al] information supplied will be kept in strict confidence. You need not write your name anywhere. Thank you very much for your cooperation.

BIOGRAFHICAL DATA

1. Sex

I1. Female

I 2. Male

* 2. A $\underline{\text { Age }}$

$71.9-12$

I7. 13-16

$\square$ 3. 17-24

I. 25-30

I 5. 31-35

$\square$ 6. 36-40

$\square 7.41-50$

I 8. 51-60

I9. 61 and over

* 3. My present occupation--major source of income

L1. Professional (doctor, nurse, minister, teacher, etc.)

12 . White collar (clerks, salespersons, colporteurs, etc.)

$[7$. skilled workmen (carpenters, plumbers, bricklayers, painters, etc.)

$\square$ 4. Semiskilled (machine operator, truck driver, nurse's aid, etc.)

$\square$ 5. Unskilled (day laborer, farm hand, helper to artisan)

46 . Unemployed or on relief (Social Welfare)

Z7. I am a housewife/homemaker and my spouse supplies the income

2 8. I am a student and my parents supply the income

I9. Other (please specify) 
4. Mar1tal status

$\square 1$. Single

$\square$ 2. Married once-still living with that spouse

$\square$ 3. Married once-lost that spouse by death

74. Married once-separated from that spouse

$\square$ 5. Narried once-divorced from that spouse

$\square$ 6. Married more than once-still living with last spouse

I7. Married more than once-divorced or separated from last spouse

D. Narried more than once-lost the last spouse by death

$\square 9$. other (please specify)

5. Iength of marriage

D1. Less than one year

$\square 2.1-3$ years

$\triangle$ 3. 4-6 years

$\square$ 4. 7-9 years

I 5. 10-14 years

I6. 15-19 years

$\square 7.20-29$ years.

I8. 30-39 years

$\square \%$. 40 or more years

* 6. My present church affiliation

Z1. None

Z.2. Seventh-day Adventist

I 3. Other Protestant

7 4. Catholic

1 5. Jewish or other non-Christian religion

0 . Child in Adventist home, but not yet baptized

$\square 7$. Other (please specify)

* 7. Length of time I have been a member of my present church as Iisted above

$\square 1$. Less than one year

$12.1-5$ years

$\square$ 3. 6-10 years

$\square$ 4. 11-20 years

5. 21-40 years

$\square 6$. Over 40 years

I7. Child, not yet baptized 
8. Church affiliation of my spouse

$\square$ 1. None

$\square 2$. Seventh-day Adventist

$\square$ 3. Other Frotestant

7 4. Catholic

$\square$ 5. Jewish or other non-Christian religion

$\square 6$. Other (please specify)

9. Length of time my spouse has been affiliated as listed above

$\square 1$. Less than one year

$\square 2.1-5$ years

$\square$ 3. 6-10 years

4. $11-20$ years

$\square$ 5. 21-40 years

$\square 6.0$ over 40 years

* 10. Miy educational background

Z1. Graduate of a professional degree program(F.A., Fh.D., D.D.S. etc.)

$\square$ 2. A degree from a 4 year college program(B.A., 3.S., etc.)

$\triangle 7$ 3. Some college but did not graduate

74 . Business or trade school(beyond high school)

$\square$ 5. High school graduate

$\square$. Some high school but have not finished

$\square 7$. Apprenticeship or manual arts education(less than high school)

$\square$ 8. Elementary school graduate

$\square$ 9. Some elementary school but have not finished

11. Educational background of my spouse

$\square$ 1. Graduate of a professional degree program

$\square 2$. A degree from a 4 year college program

$\square$ 3. Some college but did not graduate

$\square$ 4. Business or trade school

$\square$ 5. High school graduate

$\square 6$. Some high school but have not finished

$\square 7$. Apprenticeship or manual arts education

$\Pi$ 8. Elementary school graduate

$\square 9$. Some elementary school but have not finished 
FERSONAI CHRISTIAN EXFERIENCE

* 12. I consider myself at the present time

$\square$ 1. To be a Christian

$\square 7$. Not to be a Christian

$\square$ 3. Not sure that I am a Christian

$\square$ 4. Not sure what it means to be a Christian

* 13. My actions show that I usually

$\square 1$. Love both God and man

$\square 7$. Love God but not man

$\square$ 3. Love man but not God

$\square$ 4. Love neither God nor man

* 14. Ny actions show that I am a Christian because right now I am

$\square$ 1. Living for Jesus in all aspects of my daily life

$\square$ 2. Living for Jesus in most aspects of my daily life

$\square$ 3. Living for Jesus in a few aspects of my life

[7.4. Keeping the 10 commandments for Jesus and living the rest of my life my way

$\square$ 5. Trying to do good to other people without regard for Jesus

$\square 6$. Other(please specify)

* 15. To be a believer in Jesus as my javiour means

$\square$ 1. I do not yet understand what it means

$\square 2$. Simply a mental exercise

$\square$ 3. Simply an emotional experience

$\square$ 4. Involves a decision to accept Jesus' death on the cross for my sins and involves a personal growing love relationship with Him

$\square$ 5. Other (please specify)

* 16. I believe that a true Christian will

$\square 1$. Be saved by his own good works alone but faith in Christ will follow his works

\2. Be saved by faith in Jesus alone but good works will follow his faith

$\square$ 3. Be saved by falth plus works

$\square$ 4. Other (please specify) 
* 17. If necessary, I would be willing to sacrifice anything for Christ

1. Never

$\square$ 2. Seldom

$\square$ 3. Occasionally

$\square$ 4. Regularly

$\square$ 5. Almost always

I6. Always

18. When a person is accepting Christianity

$\square 1$. He is primarily accepting a body of doctrines

$\square$ 2. He is primarily accepting a Ferson (Jesus Christ)

$\square$ 3. He is acceting both the Ferson (Jesus) and His teachings

$\square$ 4. Other (please specify)

* 19. Taking time for personal devotions (Bible study, meditation, or devotional reading other than family worshipj each day

$\square 1$. Is important to me

$\square 2$. Is not important to me

$\square$ 3. I'm not sure yet whether or not it is important to me

* 20. Fersonal devotions are important to me

$\square$ 1. But I always have a hard time doing it

$\square 2$. And I have an easy time doing. it

$\square$ 3. And I sometimes have a hard time and sometimes I have an easy time doing it

* 21. The frequency with which I scend time alone with God in personal devotions

I. Not at all

$\square$ 2. About once or twice a month

$\square$ 3. About once or twice a week

$\square$ 4. About five days a week

$\square$ 5. I rarely miss a day

$\square 6$. I have it every day for a period of time, and then all of a sudden I might get extra busy and not have it for a week or more

$\square 7$. Other (please specify) 
* 22. My time alone with God in personal devotions

$\square 1$. Is an enjoyable experience for me

$\square 2$. Is a time I really dread

$\square 3$. Is not elther enjoyment or dread, and instead is rather routine and ritualistic

I4. Other (please specify)

* 23. My personal devotional life is

$\square 1$. Something I usually look forward to eagerly

$\square$ 2. Something I usually don't eagerly anticipate, but feel guilty about if I leave it out

$\square 3$. Something that affects my feelings in no way at all

$\square$ 4. Other (please specify)

* 24. My frequency of private prayer

$\square$ 1. At least once a day

$\square$ 2. More than once a day

$\square$ 3. Three to five times a week

$\square$ 4. Once a week

$\square$ 5. Once a month

$\square$ 6. Almost never

I7. Never

* 25. I feel free to talk to God

$\square 1$. Only when I'm on my knees

$\square$ 2. Only when I am in church

$\square$ 3. Only when I am having private devotions

$\square$ 4. No matter where I am or when it is

$\square$ 5. ivever

$\square$ 6. Other (please specify)

* 26. I feel free to talk to God about

$\square 1$. All aspects of my life

$\square$ 2. Most but not all aspects of my life

$\square$ 3. Only a few aspects of my life

$\square$ 4. Nothing

$\square$ 5. Other (please specify) 
* 27. I think of God as

$\square 1$. a harsh judge just waiting to catch me in sin so I will be lost

प2. A person more to be afraid of than to love

$\square$ 3. Not a person at all but a power or influence

17 . A person who really loves me, willingly forgives me, and gladly receives my response of love toward him

* 28. I believe that God would rather have me

$\square 1$. Obey Him than love Him

$\square$ 2. Obey Him because I love Him

$\square$ 3. Obey Him because I am afraid of him

17. Love Him than obey Him

* 29. God and I both know that my actions usually reveal that my supreme object of love is

I7. Myself

$\square$ 2. Spouse

$\square$ 3. Children

$\triangle 7$. Parents

$\square$ 5. Money

$\square 6$. Clothes

$\square 7$. Car

$\square$ 8. Church

$\square$ 9. Jesus

* 30. My actions show that real greatness is determined for me by

$\square 1$. Riches

$\square$ 2. Fame

$\square$ 3. Loving service for others

$\square$ 4. Leadership

$\square$ 5. Praise

$\square 6$. Loving those who love me

* 31. My actions show that I believe the best way to be a good Christian is to

$\square$ 1. Grit my teeth and work hard at it

$\square$ 2. Depend on church meetings to keep me strong

$\square$ 3. Lay up treasures in heaven by tithes and offerings

$\square$ 4. Gain spiritual strength from stronger Christians

$\square$ 5. Develop a growing love relationship with Jesus Christ 
HUSBAND-UIFE REIATIONSHIFS

32. At present I would evaluate my marriage as

1. Very Happy

$\square$ 2. Happy

$\square$ 3. Nediocre

$\square$ 4. Unhappy

$\square$ 5. very unhappy

33. The responsibility for the condition checked above is divided in the following way

D1. Ny spouse is completely responsible

$\square 2$. My spouse is mostly responsible

Z3. Wy spouse and I share the responsibility nearly equally

$\square$ 4. I am mostly responsible

I5. I am completely responsible

34. This condition in my marriage

$\square$ 1. Has been this way since our wedding day

172 . Has been gradually but steadily moving in this direction

I. Has gone back and forth but now it is as I stated in $\# 32$

$\square$ 4. Fias not been this way until just recently

35. I show my love to my spouse

$\square$ 1. By words but not by deeds

12 . By deeds but not by words

1 3. By both deeds and words

$\square$ 4. By neither words nor deeds

36. When my scouse wants to talk to me about little matters that have happened aurins the day I usually respond by

$\nabla 1$. Listenins and replying

$\square$ 2. Listening politely

$\square$ 3. Fretending to be listening while walking away

$\square$ 4. Ignoring him/her 
37. When my spouse wants to talk to me about relatively important matters I usualiy respond by

1. Listening and replying

7 2. Listening politely

4 3. Fretending to be listening while walking away

74. Ignoring him/her

38. When I get upset with my spouse I usually respond by

$\square$ 1. Not talking at all

$\square 2$. Fretending nothing is bothering me

I. Blowing up and getting over it quickly

17 . Lringing it up as calmly as possible at the appropriate time

I. Waiting for him/her to bring it up

I 6. Getting away from it all for a while

39. My spouse and I spend time alone tosether

$\square 1$. Never

$\square$ 2. Rarely

Z3. Only when we have to

$\square$ 4. Just on special occasions like anniversaries

$\square$ 5. As often as possible

40. My spouse and I spend our leisure tine

1. Always together

$\square 2$. Nostly together but sometimes apart

$\square$ 3. Divided nearly equally between together and apart

I 4. Mostly apart but sometimes together

$\square$ 5. Never together

41. My spouse and I eat our meals

1. Together always

$\square$ 2. Almost always together

D. Sometimes together and sometimes apart

2 4. Rarely ever together

$\square$ 5. Always apart 
42. The kinds of things we usually do together during our leisure time are

Z1. Mutually enjoyable hobbies

$\square$ 2. Independent activities but in the same room

2 3. Going places and doing thines together

$\square$ 4. Outdoor activities such as sports or gardening

$\triangle$ 5. Indoor activities such as table games or reading

6. Combination of above

77. Other (please specify)

43. If there were one thing I could change about my marriage it would be

1. Nothing

17. Something in myself

1 3. Something in my spouse

14 . Something in my in-laws

$\square$ 5. The way my parents interfere with my marriage

Z6. Other (please specify)

PARENT-CHILD RELATIONSHIFS

44. Family size

I. No children

$\square 2$. One child

$\square$ 3. 2-4 children

$\square$ 4. 5-6 children

$\square$. Over 6 children

* 45. The way children are disciplined in our home by father

$\square$ 1. Love with firm discipline

$\square$ 2. He trys $\# 1$ without always accomplishing it

Z3. Strict discipline without showing love

$\square$ 4. Love with mild discipline

$\square$ 5. Mild discipline without showing love

$\square 6$. Uncertaintydoesn't really know how to discipline

* 46. The way children are disciplined in our home by mother

1. Love with firm discipline

$\square$ 2. She trys \#1 without always accomplishing it

27 . Strict discipline without showing love

$\square$ 4. Love with mild discipline

5. Mild discipline without showing love

F 6. Uncertainty--doesn't really know how to discipline 
* 47. I do express love in our home in words and acts of thoughtful kindness and gentle courtesy

$\square 1$. Never

$\square$ 2. Seldom

$\square$ 3. Sometimes

$\square$ 4. Only when I feel like it

I. Quite often

$\square$ 6. Always

* 48. When conflicts arise between carents and children in our home it is most often resolved by (answer the real, not the ideal).

Z1. Assertion of parental authority over children without showing love

I2. Farental authority asserted while showing love

$\square$ 3. The parents give in to children's demands

$\square$ 4. Sometimes parents give in and sometimes parental authority is exercised over children

D. Farents and children work together to find mutually acceptable solutions

Z6. There is no pattern in the way we resolve conflicts

* 49. After a conflict has been resolved by our method

I1. The parents feel better but the children feel worse

$\square$ 2. The children feel better but the parents feel worse

$\square$ 3. Sometimes parents feel better and sometimes parents feel worse

7 4. Farents and children usually both feel better

$[7$. This is a variable too difficult for me to rate

$\square$ 6. other

* 50. Conflict resolution

$\square 1$. Most frequently draws our family closer together

$\square$ 2. Most frequently drives our family farther apart

2 3. Sometimes draws us together and sometimes drives us apart

17 . Other (please specify)

51. I pray for my children

$\square 1$. ofter

$\square$ 2. Occasionally

$\square$ 3. seldom

$\square$ 4. Never 
* 52. In our home the parents play with the children

$\square$ 1. Often

$\square$ 2. Occasionally

$\square$ 3. Seldom

$\square$ 4. Never

* 53. In our home the general attitude of the children toward the parents is

$\square$ 1. Love mingled with fear

$\square$ 2. Fear mingled with hatred

$L 3$. Love mingled with hatred

$\square$ 4. Love mingled with respect

$I$ 5. Respect mingled with fear

$\square$ 6. other(please specify)

* 54. Family worship, frequency

$\square$ 1. Never have family worship

$\square$ 2. Rarely have family worship

7 3. About 2-4 times a week

$\square$ 4. At least once every day

$\square$ 5. Nearly always twice a day

17 . Only on Friday or Saturday nights

$\square$ 7. Other(please specify)

* 55. Family worship, participation

1. Always conducted by parents

$\square$ 2. Always conducted by children

$\square$ 3. Conducted by parents but children participate some in worship

L4. Both parents and children share freely in leadership and participation

*. 56. Family worship, olanning

Z1. No forethought or planning

$\square$ 2. Usually depend on Sabbath School lesson papers

$\square$ 3. Only read from Bible, then pray

$\square$ 4. Only read from the spirit of Frophecy, then pray

$\square$ 5. Use wide variety of devotional sources but little creative planning

$\square$ 6. Wuch forethought and creative planning put into worships

Q7. Frayer only 
* 57. Family worship, en joyment

L1. Farents enjoy it but children don't

$\square$ 2. Children enjoy it but parents don't

$\square$ 3. Neither parents nor children enjoy it

$\square$ 4. Both parents and children usually enjoy it

$\square$ 5. Other (please specify)

* 58. Family worship, geared for which age level

$\square$ 1. Adults only

72 . Children only

7 3. Soth parents and cinildren each time

$\square$ 4. Adults sometimes and children sometimes

RELATIONSHIPS TO THOSE OUTSIDE THE HOVE

* 59. My style of Christian witness is

I1. Fassing out literature door to door

$\square$ 2. Random literature distribution to people who impress me as being interested

I3. To live a godly life and pray that others will somehow see Jesus in me

I 4. Cannot be restricted to a certain time or place but is involved with all of my daily activities

$\square$ 5... Other (please specify)

* 60. In my life as a Christian I

7 1. Never witness for Christ

$\square$ 2. Rarely witness for Christ

17 . Witness daily because witness is a life style for me

L4. Witness sometimes but not all the time

$\square$ 5. Other (please specify)

61. I usually witness for Jesus because

$\square$ 1. I feel guilty if I don't

$\square$ 2. I love people and want them to be saved

7 3. I love Christ and I really en joy witnessing

2 4. It is expected of a Christian

$\square$ 5. Other (please specify) 
* 62. I am friendly to my neishbors because it is

7 1. Ny duty as a neighbor but not as a Christian

$\square 2$. An opportunity for both friendship and Christian witness

I3. An opportunity for friendship but not Christian witness

$\square$ 4. An opportunity for Christian witness but not friendship

7. Other (please specify)

* 63. When I see a visitor at church

I1. I would like to be friendly, but I don't know what to say

12 . I am friendly if I happen to pass by them

7 3. I am so busy with my church duties or my family that I'm afraid I don't even notice them

1 4. I don't know who are visitors and who aremembers

I 5. I try to seek them out and make them feel welcome

$\triangle 6$. I feel it is the hostess' or greeters' responsibility to make them feel welcome

* 64. To our own church members I

I. Am friendly to those I know well

12 . Keep pretty much to myself

$[7$. Am usually friendly to everyone

17 . Don't usually notice other people as I am absorbed in my church or sabbath school responsibilities

$\square$ 5. other (please specify) 
"HOME: THE SCHOOL OF LOVE"

\section{A SEMINAR IN FAMILY SPIRITUAL ENRICHMENT}

\section{Evaluation Form:}

1. What happened in the Seminar that was the most helpful to you?

2. What happened in the Seminar that was the least helpful to you?

3. What suggestions would you have to improve the Seminar?

4. Comments you would like to share:

5. Overall evaluation: (Please check one) IT Excellent

IT Good

IT Fair

TI Poor 
1352 Colfax Avenue, Benton Harbor, Michigan 49022

Church Phone -- 926-8891

Dear Member:

A Famlly Spiritual Enrichment Seminar will be held soon for our Congregation and its families. You and your family are invited. Please $f 111$ in the enclosed registration form and return it to me by November 16 .

\section{DATES}

Sabbath, November 16 -- 11:00 A.M. Service

November 17 - 21, - 7:00 - 8:30 P.M.

Sabbath, November $23--11: 00$ A.M. Service POTLUCK FOLLONING

\section{1:30 - 3:30 Final Session}

Children nine years of age and older are encouraged to attend the sessions with their parents. Younger children will be cared for by students from Andrews University so that families with small children may take advantage of this excellent opportunity for Christian family enrichment.

\section{ALL MEETINGS WILL BE HELD IN OUR SANCTUARY}

Three ordained Adventist Ministers have teamed up to serve as resource personnel for this Seminar. They are:

Elder Bob Cowan,

Pastor, the past nine years in California.

Elder Des Cumings,

Campus Chaplain in Southern Missionary College

Andre Stifnman,

Pastor from the Netherlands.

Emphasis will be placed upon group involvement and activities rather than lectures. Those who attend every session will receive the most benefit from the Seminar and as your Pastor, I urge every family to make plans to be here.

In Christ,

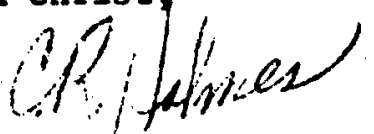

C. Raymond Holmes, Pastor

PS. There will be an offering taken at the last session to help cover expenses particularly with reference to the 
"HOME, THE SCHOOL OF LOVE"

\section{A FAMILY SPIRITUAL ENRICHRENT SEMINAR}

November $16-23,1974$, Benton Harbor, Michigan

APPLICATION FOR REGISTRATION

INSTRUCTIONS

Please f11l in the blanks below and return to the Church office by November 16. One application for each family is adequate. This SEMINAR is free of charge, but an offering will be taken at the last session to cover expenses. Regular attendance will provide the greatest personal benefits to you.

NAME PHONE

ADDRESS

ZIP

CHECK ONE OF THE FOLLOWING IN EACH CATEGORY

MALE

FEMALE

AGE ( ) Below 20

( ) $21-40$

( ) $41-60$

( ) Above 60

MARITAL STATUS

( ) Single

( ) Married

( ) Widowed

( ) Separated

( ) Divorced

IF MARRIED, NAME OF SPOUSE

AGE OF SPOUSE, in relationship to my age:

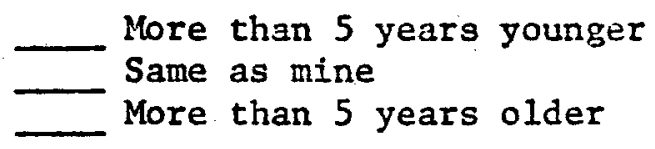

IF YOU HAVE CHILDREN, PLEASE CORPLETE THE FOLLONING -- Use back of sheet, if NAMES

1.

2.

3.

4.

5.

6. necessary
1 - 5 years younger 1 - 5 years older

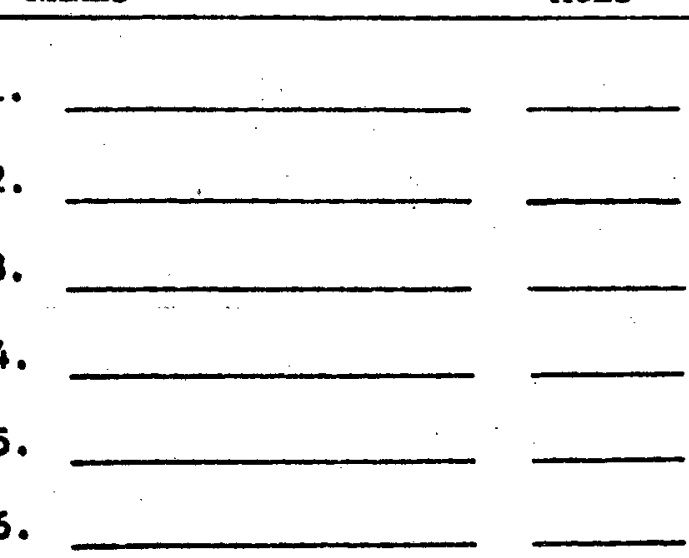
YEAR IN SCHOOL

SCHOOL ATTENDING 
CHURCH AFFILIATION

SDA

None

Other, please specify

I HEARD ABOUT THIS SEMINAR IN THE FOLLOWING WAY (Please specify)

MY GOALS AND EXPECTATIONS FROM THIS SEMINAR ARE (Please list in order of priority)

1.

2.

3. 
FP: Dt. $6: 4-7$

SUBJ: God's Love

THEME: Teaching God's Love in the Home

PURFOSE: Modification (How?)

TITLE:
Robert Cowan

November 16, 1974

Benton Harbor, Mi.

INTRO: Begin with life situations: Crises in marrlages - Farent-child relationships.

1. How would you handle the situation if you discovered your spouse was planning to leave you? Anger? Hurt feelings? Communication, love, understanding?

2. What would you do if you were a parent and your teenage daughter ran away from home but you knew where she was? Force her to come home? Call the police? or go to her with love and concern and acceptance and communicate to discover why she was so unhappy at home that she decided to run away?

3. Suppose you are a nine year old boy and your father has just broken his promise again to take you out camping, how would you feel and what would you do? Go pout in your bedroom? Decide to never forgive your father? or talk to your father about your feelings?

PROF: Every Christian parent can transform nis home into a school of love T.S.: by following the words of God given to us by voses in Dt. 6: 4-?

I. LOVE GOD SUFREPELY

1. Love cannot be commanded.

2. Love awaken's love.

3. Love for God was awakened in Israel by deliverance from slavery in Egypt.

4. Love for God is awakened in us by deliverance from slavery to sin (in Benton Harbor) by Jesus on the cross.

II. KEEF GOD'S WCRDS IN OUR HEARTS

1. It is important to keep God's word. But, it is even more important to know where to keep it. Because if you keep it only outside your heart it will rapidly become a legalistic form, a cold external, a doctrine of works, a humanistic philosophy. But, if we keep it in our heart it permeates the entire life, it motivates the whole being, "Keep thy heart with all diligence for out of it are the issues of Iife." Frov. 4:23.

III. TEACH COD'S IOVE AND GOD'S WORD TO OUR CHILDREN

1. How? By both precept and example, diligently communicate.

2. When? sitting in your house

walking by the way

lying down - bedtime prayer or evening worship

rising up - morning worship

CONC: Therefore, every Christian parent can transform his home into a school of love by 1). loving God supremely, 2) keeping God's word in our hearts, and 3) teaching Cod's love and word to our children. This whole week will be devoted to understanding better How to do it. 
"HOME: THE SEHOOL OÉ LOVE"

ORIENTATION

"EXcept the Loro builo the house, they labour in vain that guilo it." PSALM 127: 1

LOVE FOR GOD ANO LOVE FOR MAN ENCOMPASSES GOO'S WILL. MARK 12:28-34

LOVE FOR CHRIST IS THE ONE TEST OF DISCIPLESHIP CHRIST ASKED OF PETER. JOHN $21: 15-17$

THE CULTIVATION OF CHRIST'S LOVE IN THE CHRISTIAN TAKES TIME.

"THE VERy gest way to reform the character ano regulate the conduct of your FAMILY IS THROUGH THE PRINCIPLE OF LOVE." $4 T 250$

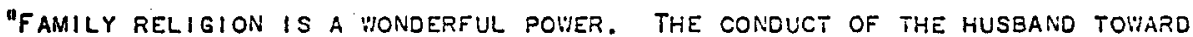
THE WIFE ANO OF THE WIFE TOHARD THE HUSBaND VIAY BE SUCH THAT IT WILL MAKE THE HOME LIFE A PREPARATION FOR ENTRANCE TO THE FAIAILY. ABOVE.

"HEarts that aRe fILLEO WITH THE LOVE OF CHRIST CAN NEVER Get VERY far APART. RELIGION IS LOVE, AND A CHRISTIAN HOME IS ONE HHERE LOVE REIGNS AND FINDS EXPRESSION IN YORDS ANO ACTS OF THOUGHTFUL KINDNESS AND GENTLE COURTESY.

"RELIGION IS NEEDED IN THE hONE. ONLY THIS CAN PREVENT THE gRIEVOUS WRONGS WHICH SO OFTEN EMBITTER MARRIED LIFE. ONLY YHERE CHRIST REIGNS CAN THERE BE DEEP, TRUE, UNSELFISH LOVE. THEN SOUL WILL BE KNIT WITH SOUL, ANO THE TWO LIVES WILL BLEND IN.HARIONY...

"IN EVERY faMILY WHERE CHRIST ABIDES, A TENDER INTEREST aND LOVE WILL bE MANIFESTED FOR ONE ANOTHER; NOT A SPASMODIC LOVE EXPRESSEO ONLY IN FONO CARESSES, BUT A LOVE THAT IS DEEP AND ABIDING." AH. 94

"love is a plant of heavenly origin, and if we mollo have it flourish in our HEARTS, WE MUST CULTIVATE IT DAILY." 6BC 1091-2

"Salo Christ, 'Love one another, as I have loved you;'. - .those who live MERELY FOR 'ME AND MINE' WILL FAIL OF HEAVEN. GOD CALLS UPON YOU AS A FAMILY TO CULTIVATE LOVE." 3T 529-31

"In order to have the max take a clear, strong inffession of the seal, you DO NOT DASH THE SEAL UPON IT IN A HASTY, VIOLENT HAY; YOU CAREFULLY PLACE THE SEAL ON THE PLASTIC WAX, AND QUIETLY, STEADILY PRESS IT DOWN, UNTIL IT HAS HARDENED IN THE MOLD. IN LIKE MANNER DEAL WITH HLINAN SOULS.

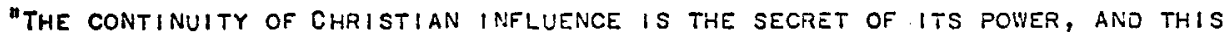
DEPENDS ON THE STEADFASTNESS OF YOUR MANIFESTATION OF THE CHARACTER OF CHRIST." MH 494

"THIS UNION WITH CHRIST, ONCE FORMED, MUST BE MAINTAINED. CHRIST SAID, "ABIDE IN ME, AND I IN YOU. AS THE BRANCH CANNOT BEAR FRUIT OF ITSELF, EXCEPT IT ABIDE IN THE VINE; NO MORE CAN YE, EXCEPT YE ABIDE IN ME.' THIS IS NO CASUAL TOUCH, NO ON-ANO-OFF CONNECTION. - .

"A profession of RELIGION places MEN IN THE CHURCH, BUt tHe character and CONDUCT SHOW WHETHERTHEY ARE IN CONNECTION WITH CHRIST. IF THEY BEAR NO FRUIT, THEY ARE FALSE BRANCHES." DA 676 
"HONL: THL SCHOOL OF LOVE"

\section{by Boib Cowan}

"CHARIII SHEDD'S FIVE GIFTS THAT WILL GUARANTEE A TURNED-ON MARRIAGE"

1. TAKL TIMi AIONE TCGLTHER. Invest time together. Go out for dimer once a reek. When he it his wife have guests in their home overnight they will often get up early and go olit to a restaurant to eat breakfast together.

2. GIPT OF A SIMPIS CONEIIENT. Once each day, and give a new one once each week. Say at night before going to bed, "What was your happiest moment today?" Then share with each other what your happlest monents were.

3. GIFT OF SURFACDD HOSTILITIES. Never hide things for more than 48 hours. Bible - "Let not the sun go down upon your wrath." Talk things over. Don't hold grudiges or heartaches in to fester and become worse. Get it out in the open where you can harale it together and work it thoough to an uncerstanding.

4. GIFr OF NUTUAL SELF-ATALYSIS. Spend 15 minutes each day sharing with each other what is going on inside of you. e.g. Waslow's book is read separately by each spouse during the day, a few pages or a chapter. Wherever one identifies himself/herself they write "me" in the colunn. Never write the other persons name there. Look only for yourselit to be identified. The "me's" are written in each other's om handwriting. Then discuss what you mean by "me" there and ask what the other one thinks about that. Women all over the world have one common promlem - they csm't get their husbancis to talk.

5. GIFT OF PRAYER IN DURT, Serious, depti, prayer together. Relive the love and close experiences of your courtship. Have idRCy toward each other. 


\section{7}

"ruid's THE SCHOOL ON IOVL"

\section{FAMILY CONIUNICATION}

Andre Stijnman, 10 minutes, "How Television Interferes with Family Communication" Des Cummings, 10 minutes, "Teenager-jarent Communication"

Bob Cowan, 10 minutes, "Charlie Shedd's Five Gifts That Will Guarantee A Turned-On Marriage"

1. GIFT OF TAKING TIML AIONE TOCETHER

2. GIFT OF A SINPLE COMPLINENT

3. GIFT CF SURFACED HOSTILITY

4. GIFT OF NUTUAL SELF-ANALYSIS

5. GIFT OF FRAYRR IN DUET

\section{GUIDELINES FOR PARENTS}

1. Fass on faith and trust in God to your children--through daily living, family prayers, and Biole study.

2. Show love and acceptance--in simple daily expressions and words of appreciation.

3. Iisten--rot only to worcis, but hear the "heartbeats." Identify with their feeiings. Understand their outioursts.

4. Be avallable--to play, talk, or deal with issues when they want to, not just when it suits you.

5. Teach values-respect, responsibility, self-aiscipline. These help them face life.

6. Provide occasions for sharing--hobbles, recreation, fun times, anc work.

7. Set limits--with love, consistency, and firmness. II ignored, they are responsible for consequences.

8. Relax--an uptight parent produces uptight chilaren.

9. Allow them to make decisions--whenever possible.

10. Affirm each as a person of worth--created by God for a special purpose.

IOVN NEVER FAIIS. These guidelines were printed on a postcard known as Card \#5, by Heart to Heart publications, Harrisonburg, Virginia 22801. "Heart to Heart

is a radio broadcast bringing Christian inspiration to homemakers in tine midst of everyday tasks." (Courtesy of John Youngberg, Berrien Springs, Vichigan.) 
if $1 /$ hen I stopped praying for my wife

and children, great things happened.

My own allitures changed. I began to

see the members of my family in a nevi

light. They became real persons. And

it became easier to love them more

deeply in spite of faults. Mistakes took

a more minor role in re'atiunships.

Often in the past 1 prajed prayers

like. "Lo:d, help my son to be a goed

boy. Change his attitudes. Loril. Hclp

him to a doubie dose of divite love.

May he be kind and more pleusant in

all our fanily relationships. Ile.p him

to be obedient."

For my daughter I prayed that she might know Christ's love and discern. as she grows to maturity. what true love is in every relationship.

And for my wife I praysd that God might give her stienglt for all her daily duties in the home. I proyed that she inight have plenty of patience with the children and that she might get all done which should be done to linep our home going smoothly. I prayed that as a busy mother she m: sht have extra helpings of gráce.

Then one evening it happened. I was alone when suddeniy it struck me that this kind of prayine must stop. It seeneri my prayers reaily didn't help. If anything, the chiddren knew less about love than in their earlier years. Traits such as caring and kindness, 1 feared at times, were decreasing. And I realize-i I must stop prayins for then. I realized I was praying for thie wrone person. I was short in praying for the one who really needeo prayer.

So I stopped praying prayers like the above ior my iamily. I rearice in irai if my childron were to kno:: Christ's love, then las their father needed to expericnse mere of Christ's love and make that love visib!e. If they were ever to learn true love in retationship to others, than I would rieec divine aid to dumonstrate true love in all my relationships with them an:! others. So my prayer turned to. "Lord, make me fit to live vithi; loving and kind as yo:ı are to me."

I stopped praying proje:s like the above for my wife when I realized that my jo's was no: to matea lice zood but to riske her hamay. I resileej that my

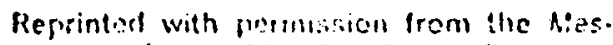
senger of the Cliureli ci live Brethern. Allistst 15. 1971. The author is editor of the Cinsnel Merato. Westly mublicaion of the Annionite Publishine House.

prayer should not be for God to help her get all her work done. It was to ask God to help me see those places where 1 could help her and make it easier for her. My prayer now turned to. 'Lord, make me a real 'helpmeet,' eager and happy to do all $I$ can to make my wife happy." I realized I was the one who needed extra holpings of God's grace.

From that night on my world was changed. My home changed. It suddenly seemed that my vilic and children changed. A riew atmosphere of love pervaciss the house and even the car when we go driving. The children seem mere kind. And it all started when I stopped prajing for them and beean to pray for Cod to give me a now attitude; when I asked God to help me refrain from all which might hurt those I love or hirider relationships; when 1 told God that I want to do all within my poiver what needs to be done to make my chidoren and wife happy. Something hapfened when I wanted God to change me more than I vianted him to change other persons.

No, it hasn't been perfect. I. goof and I'm sorry. But l've learned that my family loves me right through my mistakes.

Of course, I still pray. My vife and chilciren are as much in my projers as ever. But now my prayers arc primarily prayers of thanksziving for each one. And I believe that God desires this lia:d of praying. because it also horors him who gave each one to me. Lilc really took on new mean. ine and li.appincss when I stopeed asking Gol to chenge others and askeu him to change me. II 


\section{Tinne}

Time.

It hangs heary for the bored, eludes the busy, llies by for the young, and runs out for the aged.

Time.

We talk about it as though it's a manufactured cumodity that some can afford, others can't; some can reproduce, others waste.

We crave it. We curse it. We kill it. We abuse it. Is it a friend? Or an enemy? I suspect we know very little about it. To know it at all and its polential, perhaps we should view it through a child's eyes.

"When I was young, Diddy was going to throw me up in the air and catch me and I would giggle until I couldn't giggle any more, but he had to change the furnace filler and there wasn't time."

"When I was young. Mama was going to read me a story and I was geing to lura the pages and pretend I could rcad, but she had to wax the büthroein and ticie inisis't time."

"When I was young, Daddy was going to come to school and viatch me in a play. I was the fourth Wise Man (in case one of the three got sick). but he had an appointment to have his car tuned up and it took longer than he thought and there vas no time."

"When I was young. Grandma and Grancidad were going to come for Christmas to see the expression on my face when I got my first bike, but Grandma didn't know who she could get to feed the dogs and Grancdad didn't like the cold weather, and besides, they didn't have the time."

"When I was young, Mama was going to listen to me read my essay on 'What I Want to Be When I Grow Up' but she was in the middle of the 'Monday Night Movic' and Gregory Peck was always one of her favorites and there wasn't time."

"When I was older, Dad and I were going fishing one weekend, just the two of us, and we were going to pitch a tent and fry fish with the heads on them like they do in the flashlight ads, but at the last minuie he had to fertilize the grass and there wasn't time."

"When I was olcier, the whole family was always going to pose together for our Christmas card, but my brother had ball practice, my sister had her hair up, Dad was watching the Colts, and Mom had to wax the bathroom. There vasn't time."

"When I grew up and left home to be married, I was going to sit down with Mom and Dad and tell them I loved them and I would miss them. But Hank (he's my best man and a real clown) was honking the horn in front of the house, so there wasn't time."

Erma Bombeck

From Ermo Bonbeck's Al Wit's End, Courtesy of Publishers-Hall Syndicate. 
FF: John 13:31-35

SUBJ: Love

THENE: Love for one another

PURFOSE: Modification (riow?)
Robert Cowan

November 23, 1974

Benton Harbor, Mil.

TITLE:

A New Comnandment

INTRO: Last Sabbath we read the words of Jesus as he quoted from Dt. 6 then added to it in $\mathrm{Fk}$. 12:31 - Love your neighbor as yourself. This week we see Jesus giving a new commandment in John 13:34 "love one another as I have loved you." The test of discipleship is love for one another.

FROP: Every Christian can learn to follow the new commandment, T.S.: if we can find out how Jesus loved His disciples and follow His example beginning with Join 13: 31-35.

I. HE LOVED TIEM IN SFITE OF THEIR FAULTS

1. He bore patiently with Judas - His betrayer

2. He bore patiently with Leter - The one who denied Him

3. He bore patiently with liatthew

4. He bore patiently with them on the lake in the storm

5. He bore patiently with them in a garden of prayer

6. He bore patiently with them when tiney could not cast out the unclean spirit after the transfiguration

7. He bore patiently with the Samaritan woman

8. He bore patiently with the woman taken in adultery.

II. HE LOVED THEY ENOUGH TO SERVE THEY

1. Crdinance of humility, Iohn 13:1-17

2. He prepared fish and bread by the seashore when they were through fishing all night after the resurrection

3. He walked 2 miles to Emmaeus with the 2 disciples (husband and wife?) after the resurrection and broke bread for them.

III. HE LOVED THEM ENOUCH TO DIE FCR THEM

1. He said, "as I have loved": this implies in the past, before the cross

2. But the disciples did not fully understand Jesus' love until after He had died on the cross

3. Neither can we fully understand it until we understand the cross

CONC: "Were you there when they crucified my Lord?"

Therefore, we can learn to love others as jesus loved us if we will

1. love peopie in spite of their faults,

2. love them enough to serve them, and

3. love them enough to die for them. 


\section{A VERBATIM SUMMARY}

\section{OF EVALUATION SHEETS, BENTON HARBOR SEMINAR}

\section{QUESTION 1: What happened in the Seminar that was the most helpful to you?}

Probably Des Gummings talks and the chance to make some new friends.

Many ideas were given that believe [it] or not was (sic) quite foreign to me. $I[t]$ also brought my life in better focus to me and my family.

The informal fellowship. I appreciated the emphasis placed on individual prayer and study. The willingness of everyone to share their shortcomings and a desire to have worship was an encouragement.

1. Being able to hear a subject presented then hearing others views based on their life experiences \& having a chance to see the reaction of others when you tell your feelings on same subject.

2. Having children cared for so you function with all your thoughts.

Introducing us to daily devotionals \& what to use. Keeping the sessions on a very practical every day level.

The organization was such that one could not just sit \& listen, but rather made it necessary to discuss--acknowledge the points, and make a committment. Relaxed atmosphere, where all share.

Discussing personal worship.

The Seminar was a chance to get together with Church members and discuss not only family problems but Church problems.

About talking with God more and agreeing with parents.

Learned more about having a happier home.

1. Admission of things wrong. 2. Discover needs. 3. Plan for something better.

The practical \& real presentation of actual ways that people can relate to other people in caring. (Not judging, or disciplining.) Love is the mightiest force in the world, not whipping, or retaliating. Love will always motivate more than a fear of reprisal. A look of sad regret is always more effective than a blow, but only if the proper ground work is laid \& a person is tender hearted, sensitive \& receptive. I see so many parents yelling at their kids \& I really appreciate the work you are doing here. We should be seeing some positive results.

Elder Cummings talking about conflicts, barriers, and throwing stones. 
It has been the most thought provoking series of meetings I have been to in a long time (years) (discipline with love).

All of it was helpful.

I learned more about my own problems and how to work them out with Jesus help. Also how to help my small children and how to show them I love them and that Jesus loves them most of all. How to deal with family problems fairly.

I enjoyed the exchange of ideas. Although our girls are grown--It helped me to see where I could improve--If too late with the children, maybe in helping the grandchildren.

Probably most all of it but most of all was (when he comes).

Knowing that we as parents aren't alone in our problems.

Everything.

Introduction to personal devosions. (sic)

Sharing.

Helped draw me closer to my family.

I thoroughly enjoyed the informalness \& group discussions. Good "refresher" course.

The meeting on discipline.

All instruction were good.

All were good.

Getting a personal worship going.

2 get started with private worship dayly. (sic)

Every thing.

Group discussions to know others are--or have been--battling some of the same things you are and that they can be overcome.

Communication--Openness. Learn to be positive \& truthful.

An awareness of better communication, love, and being a family who will make heaven.

That preacher Desmin (sic) or something's talks. He preached good!

The openness and candidness of everyone, getting to know each other better. Brother Andre's presentation was thrilling to me--the one on 
worship. I felt fed, and a new thrill in being part of the Advent movement. Having Brother Cummings "analyze" \& illustrate our feelings were very helpful--with the charts \& refreshing style.

Love-discipline discussing, also discussion of family communication. All of it.

1. Insight into the churches personalities. 2. Reexamination of our home \& my personality.

It caused me to look closer at myself.

Discussing in larg (sic) gruops (sic) most.

About the T.V.

The suggestions for personal and family worship.

Personal davotions. (sic)

Got the group to bare their innermost problems.

QUESTION 2: What happened in the Seminar that was the least helpful to you?

I don't know.

The film on witnessing broke the continuity and fellowship even though it was interesting. I feel as though we missed one night as far as family fellowship is concerned. area.

1. Went to (sic) fast. 2. Not enough time given to each subject

All was helpful.

I work all day and in the evening I am very tired. Therefore I am very weary by the end of the week when I go out every night.

About controlling other peoples (sic) kids.

$?$

None of it was unhelpfu1. A11 was just a little bit helpful.

Everything was helpful:!

The T.V. bit ("we don't have one anyway")

Lost (sic) of sleep.

Everything was helpful maybe not at present but in the future. 
Nothing was "not helpful."

Nothing.

Its all been interesting.

I enjoyed it very much

Nothing.

I really enjoyed it a11.

As far as family, Thurs. nights meeting, although Bible study knowledge great.

I liked it al1.

Thursday night (Eld. Lang) was good in itself, but it was the one night I didn't quite feel the same sense of fellowship with everyone. It seemed to be in a different "category", or something--hard to put into words.

?

Not one thing--it was all good.

Time for one wis[rest of word unintelligible]

Throwing stones.

Worship.

QUESTION 3: What suggestions would you have to improve the Seminar?

None I think it was real nice.

Longer time.

Have a question and answer period. We could ask specific questions on discipline and get some ideas from the leader and others.

1. Seminars such as these should be shared by a church more often.

Longer--not each night, but more evenings. (What I mean is more than 5 nights)

More of the discussion groups to be group rather than family. Some family group is $0 . \mathrm{K}$., but is good to know more of other family problems-solutions etc.

I think you could make it a whole series of studies, but for the length of time we spent it was good. 
I would have liked the members of the Chruch to have a chance to discuss some of our particular problems i.e. lack of leaders or teachers in S.S. depts. and why.

Call on the kids more.

To have it once every week instead of every night.

A "follow up" plan for Church as a family together.

Very well planned, be shure (sic) to keep showing a personal interest in people. This has been one of the best parts of the series.

Have more group sessions.

Just want to say God Bless us all for believing in the Lord.

I felt that the church was not given a better idea of the seminar-and that if there had been a little more insight--more families would have attended.

You should have more time for a metting (sic) and to last long. (sic)

Concentrate on fewer subjects.

Have it for about 2 wks instead of one. Have a meeting for husbandwife relationship.

Have them more of ten. Get everyone involved:

More group discussion.

Very good just as it was.

None.

Might have people call one another to see how their week is going and how their worship both personal and family is going.

None.

Stronger emphasize of husband/wife relationship.

Get more out.

Keep on the key (theme) started with and not open it up to everyone on Sabbath.

None.

The only "group" conspicuously absent were the teens--academy age, I don't know how they could have been made to attend. They would have benefited (sic) if they'd have come. 
Longer--perhaps 3 nites/wk (sic) over several weeks. Maybe coverage a bit more limited in scope--more time to "chew on the meat".

More of them.

More teenagers should be present. Even if for only 1-2 nights. Have more and different things.

Using a P.A. system so I could hear discussions better.

Spread out over longer period.

QUESTION 4: Comments you would like to share.

Maybe a fellowship group could sorta(sic) follow this where we could share our thoughts. Do it once a month informally instead of regular prayer meeting. Would help prayer meeting attendance also.

I had hoped our family life would be more like God's will for each family and you've more than met my expectations. Thanks \& praise the Lord for your efforts. God bless your ministries!

Thanks to you \& all your families for sharing these evenings with us.

Liked the we11-planned program. Start on time end on time.

I really wasn't enthused about it all. I tho't (sic) what a bore it would be. But was very interesting and you changed my mind.

It will make it easier to communicate with my parents.

This seminar has drawn us closer together as a Church. We need more on the family. I've been at this Church for about seven or eight years, we've never come together representing an endeavor for home improvement. How can a Church produce \& be close when things are not right at home?

I really think it helped me [a] lot I wish some of the other people that I know could have been here.

Enjoyed this Sab. pre. mts. Exchange of ideas. We can so easily condemn other members instead of just a word of encouragement.

None.

God bless you in your work for the Lord.

I enjoyed every meeting thoroughly.

Praise the Lord: In Christ and of Christ only can we grow.

This seminar was fust [the] thing I needed to give my relationship 
a Iift.

\section{None.}

We are really having some problems in our home and I feel a great need for prayers as I am sure there are others in the same situation.

I wish we could learn to do this without someone else coming in. We love you $\&$ what you've done but it won't last until we do it ourselves.

E1der Cowan, as one conducting the program you are excellent in your approach. God bless you.

I liked the speakers.

The thing that I appreciated most was the depth and sincerity of all those in charge. I instinctively trusted them. What they said rang true, was solid and something I could digest. In other words, the whole tone and spirit was heartwarming and inspiring. I attended because I wanted to; not something I had to "endure," but something I enjoyed. Our church's love-quotient and trust-quotient has been raised. Real respect for the leadership. High calibre, yet humble \& lovable.

Felt it could be an excellent tool to draw members of church as well as family closer together.

QUESTION 5: Overall evaluation: (Please check one)

IT. Execellent 36

$I T$ Good 6

$I$ Fair 0

IT Poor 0

1 did not check any

2 checked both excellent and good

1 checked $1 / 2$ way between excellent \& good

46 TOTAL NUMBER OF EVALUATION FORMS FILLED OUT 


\section{Seventh-day Adventists}

1352 Colfax Avenue, Benton Harbor, Michigan 49022

Church Phone 926-8891

February 17, 1975

Eder Robert Cowan

Andrews University

Berrien Springs, Michigan

Dear Bob:

First of all I want to thank you for accepting my invitation; and that of the Church Board, to conduct a Family Enrichment Seminar here in Benton Harbor. The Seminar was well planned and was received with much enthusiasm on the part of the members. I was extremely pleased with the high attendance during the week, as I know you were. Many comments have beon made by participants expressing appreciation for the Seminar and sharing blessings received. There are two things that I want to call to your attention concerning the Seminar which I am sure you will welcome as you plan such emphases in your future ministry。

It was my reeling, and that of some others of the participanta, that the continuity and impact of the week was broken by the inclusion of brother Lange's presentation on the Thursday evening of his Farth: Theatre of the Universe. His presentation was excellent and the materials he reviewed certainly seemed outstanding. However, in the context of the seminar it did seem out or place and appeared to a number of us as a commercial selling attempt.

on the positive side the seminar served to expose one very sorious need in this parish. As you recall, a number of the younger couples indicated that they had been unsaccessful in developing habits with respect to daily Biblo reading. They expressed themselves as "gotting nothing out of" reading the Bible. This of course became a serious matter to me You will be interested to know that on March 5 th we shall begin a spocial series of prayer meetings devotod to the theme of "Learning to Use the Eible Devotionally." Special matorials are being prepared for a ten-week prayer meeting emphasis. As of this date 26 people have indicated that they will attend. More are anticipated.

In my judgement you would not be out of line if you considered the Seminar a success.

Cordially,

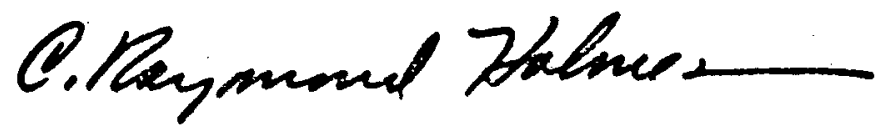

C. Raymond Holmes,

Pastor 
THE KEY TO SUCCESS IN CHRISTIAN LIVING

IS A FRIVATY DEVCTIONAL LIFE

I. THE EXAMFIE OF JESUS

A. Childhood - "The child Jesus did not receive instruction in the synagogue schools. His mother was His first human teacher. From her lips and from the scrolls of the prophets, He learned of heavenly things. . . Since He gained knowledge as we may do, His intimate acquaintance with the Scriptures shows how diligently iis early years were given to the study of Cod's word. And spread out before Him was the great library of Cod's created works. - Every child may gain knowledge as Jesus did." DA 70

B. At the beginnins of His ministry - "And Jesus answered him/the devil/, saying, It is kititen, That man shall not live by bread alone, but by every word of God." Luke $4: 4 \mathrm{KJV}$

C. At the end of His earthly ministry - "Eut he often withdrew to the wilderness for prayer." Luke 5:16 Li "Then, accomnanied by the disciples, he left tre upstairs room and went as usual to the Nount of Clives." Luke 22:39 iE (KJV="as he was wont). "Jesus ofttimes resorted thither/the garden of Gethsemane 7 with his disciples." John 18:2 ("Jesus had gone there many times with his disciples." LiB)

II. WHY IT IS IMFORTANT FCR US TODAY

A. "Living a Christian life is kind of like shaving--no matter how well you do it today, it needs to be done again tomorrow." Quiet hour Echoes, Nov., 1974, p. 16. "Consecrate yourself to God in the morning; make this your very first work. . . This is a daily matter. Each morning consecrate yourself to God for that day. Surrender all your plans to $\mathrm{Him}$, to be carried out or given up as His providence shall indicate. Thus day by day you may be giving your life into the hands of God, and thus your life will be molded more and more after the life of Christ." SC 70

B. "Only those who have been diligent students of the scriptures and who have received the love of the truth will be shielded from the powerful delusion that takes the world captive." GC 625

C. Fersonal experience on how a lack of private devotions led to a loss of Christian living.

D. Share how there is power in parental example. "You rear a child like you throw a baseball--give it the start you can while it is still in your hands, for it must go the rest of the way by itself." Q.H.Echoes, Nov., 1974, p. 16. (A clarification is needed here, however--basebalis cannot decide to place themselves in God's hands along their journey, but a child cant)

III. SOME SUGGESTIONS ON HOW TO IMPLEMENT IT

A. What I have found to be personally satisfying.

B. Sharing of ldeas from friends. 
"And now a word to you parents. Don't keep on scoldine and nageine your cinildren, making them anery and resentful. Rather, bring them up with the loving discipline the Lord himself approves, with suggestions and godly advicc." Ephesians 6:4 Iiving Bible

"Some time ago I was shown the case of $J$. Hex errors and wrongs were faithfully portrayed before her; but in the last view given me I sar that the wrones still existed, that she was cold and unsymathizing with her husband's children. Correction and reproof are not given by her for grave offenses merely, but for trivial matters that should be passed by unnoticed. Constant faultinding is wrong, and the Spirit of christ cannot abide in the neart where it exists. She is disposed to pass over the good in her childicen without a word of approval, but is ever ready to bear down with censure if any wrong is seen. This ever discourages children ard leads to habits of heedlessness. It stirs up the evil in the heart and causes it to cast up mire and dirt. In children who are habitually censured there will be a spirit of 'I don't care,' and evil passions will frequently be manifested regardiess of consequences.

Whenever tine mother can speak a wora of comendation for the good conduct of her children, she should do so. She should encourage them by words of approval and looks of love. These will be as sunshine to the heart of a child and will lead to the cuitivation of self-respect and price of character. Sister J should clitivate love and sympathy. She should manifest tenaer affection for the motherless children unaer her care. This would be a blessing to these children of God's love and would be reflected back upon her in affection and love.

"Chilodren have sensitive, loving natures. They are easily pleased and easily made uriappy. By gentle aiscipline in loving words and acts, mothers: may bind their children to their hearts. To manifest severity and to be exacting. with children are great mistakes. Uniform firmness and unimpassioned control are necessary to the discipline of every ramily. Say what you mean calmly, move with consideration, and carry out what you say without deviation.

"It will pay to manifest affection in your association with your children. Do not repel them oy lack of sympathy in their childish sports, joys, and griefs. Never let a Irown gather upon your brow or a harsh word escape your lips. God writes all these words in His book of records. Harsh words sour the temper and round the hearts of children, and in some cases these wounds are difficult to heal. Childrer are sensitive to the leasit injustice, and some become discouraged under it and will neither heed the loud, angry voice of command nor care for threatenings of punishment. Rebeliton is too frequently established in the hearts of children through the wrong discipline of the parents, when if ilproper course had been taken, the chiloren would have formed good and harmonious characters. A mother who does not have perfect control of herself is unfit to have the maragement of chlldren." $39531-3$.

Family Spiritual Enrichment Seminar, "Homes the School of Iove." 
NASA GROUP DECISION GME

Name

[Quiz sheet]

Group Number

Instructions:

You are a member of a space crew originally scheduled to rendezvous with a mother ship on the lighted surface of the moon. Due to mechanical difficulties, however, your ship was forced to land at a spot some 200 miles from the rendezvous point. During re-entry and landing, much of the equipment aboard was damaged and, since survival depends on reaching the mother ship, the most critical items avallable must be chosen for the 200 mile trip.

Below are listed the 15 items left intact and undamaged after landing. Your task is to rank order them in terms of their importance for your crew in allowing them to reach the rendezvous point. Place the number $I$ by the most important item, the number $\underline{2}$ by the second most important, and so on through number 15 , the least important.
GROUP
SCORE
CORRECT
ALONE

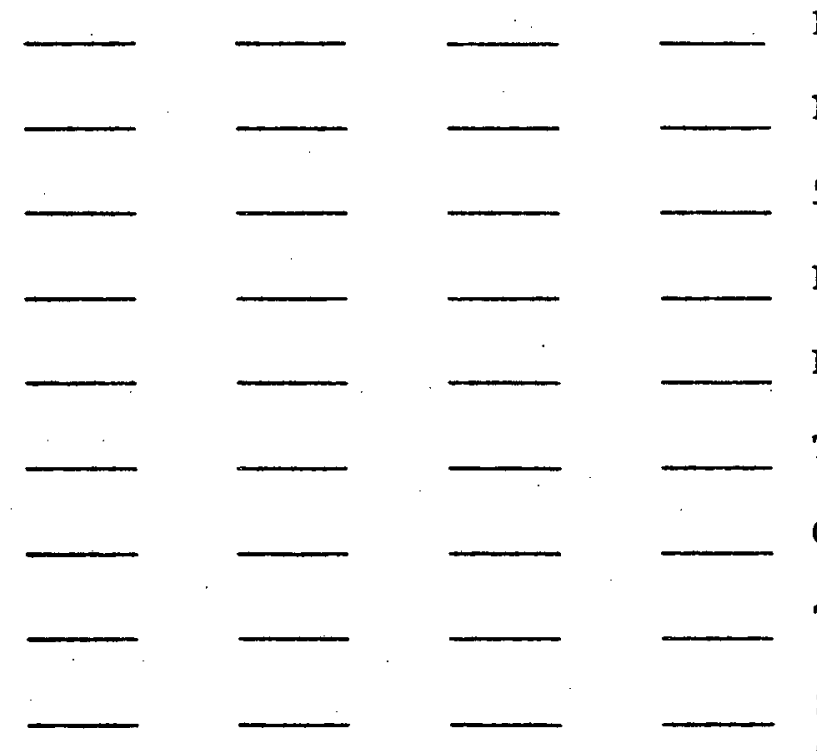
Box of matches
Food concentrate
50 feet of nylon rope
Parachute silk
Portable heating unit
Two .45 calibre pistols
One case dehydrated milk
Two $100 \mathrm{1b}$. tanks of oxygen
Stellar map of the moon's constellation
Life raft

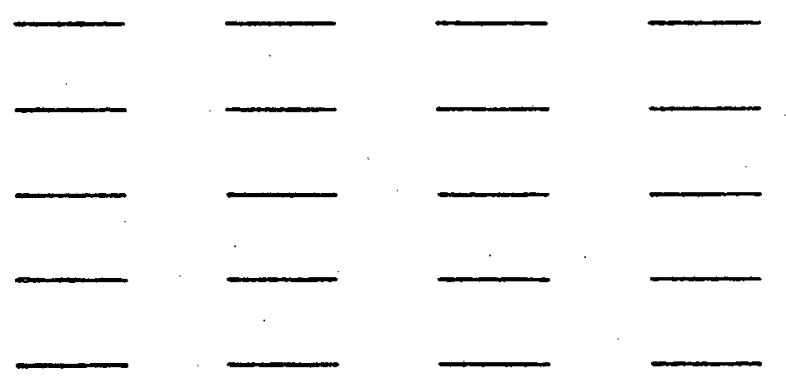
Magnetic compass
5 gallons of water.
Signal flares
First aid kit containing injection needles
Solar-powered FM receiver- transmitter 
NASA GROUP DECISION GAME [Answer sheet]
Name

Group Number

Instructions:

You are a member of a space crew orlginally scheduled to rendezvous with a mother ship on the lighted surface of the moon. Due to mechanical difflculties, however, your ship was forced to land at a spot some 200 miles from the rendezvous point. During re-entry and landing, much of the equipment aboard was damarsed and, since survival depends on reaching the mother ship, the most critical items avallable must be chosen for the 200 mile trip. Below are listed the 15 items left intact and undamaged after landing. Your task is to rank order them in terms of their importance for your crew in allowing them to reach the rendezvous point. Flace the number I by the most important item, the number $\underline{2}$ by the second most important, and so on through number 15 , the least important.

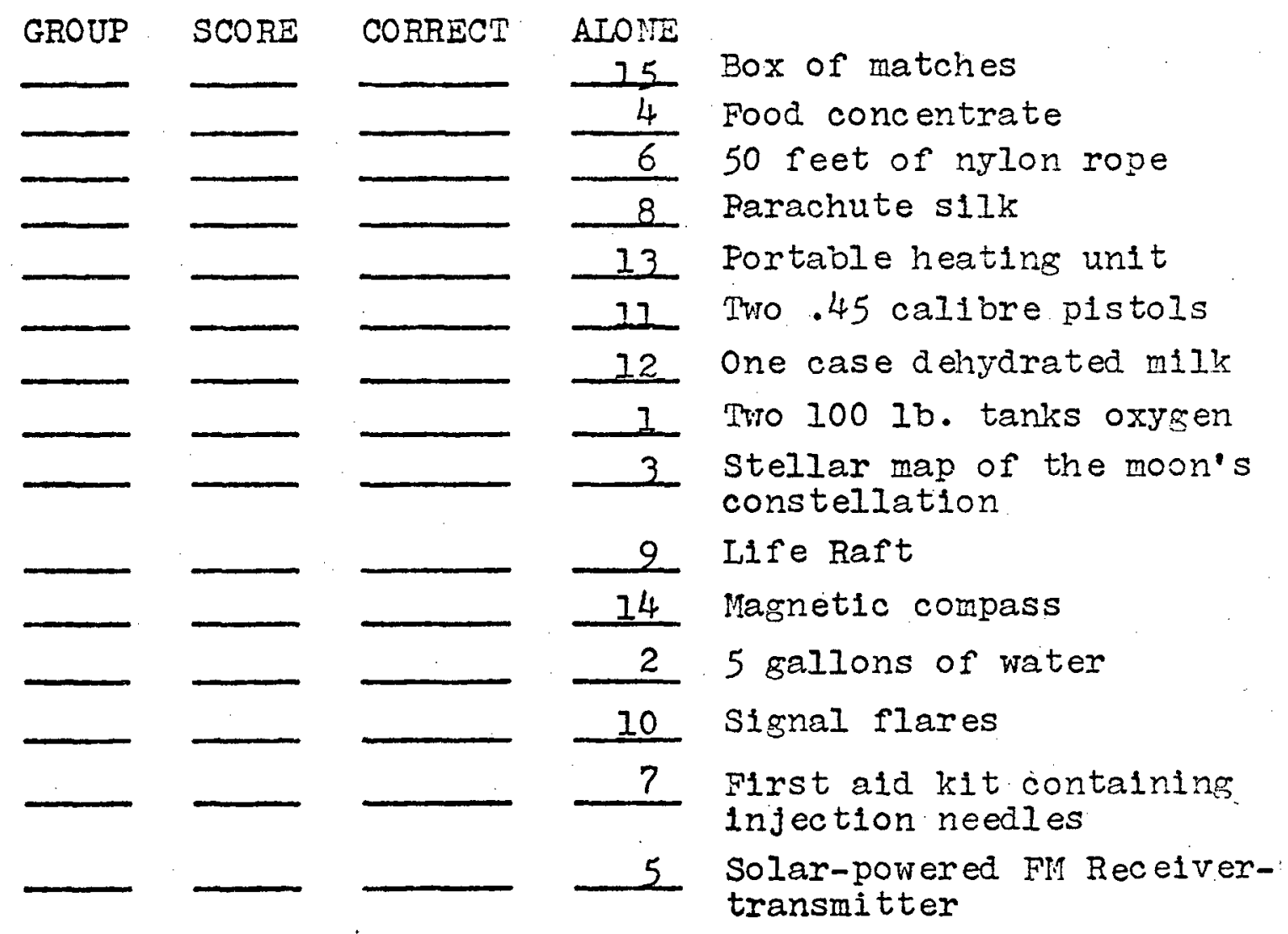


FP: Luke 19:1-10

SUBJ: Witnessing

THEME: Jesus' Witnessing Style

PURFOSE: Modification (How?)
Witness as a Life Style
Robert Cowan

November 30, 1974

Benton Harbor. Mi.

TITIE:

INTRO: Over the years, we in the church seem to have gotten the impression that witnessing for Jesus Christ is one separate activity of the Christian that happens occasionally in his life. We could compare this idea to eating food, or going grocery shopping--it is not integrated into all of one's life but just happens once in a while--when it is needed or when called for by some Church activity. In the minds and lives of many Christians, witnessing takes place only once a month on a Sabbath afternoon when the members of the church all meet at the church and go out to an assigned territory to pass out literature.

But I would like to suggest this morning that this is not an accurate picture or a complete understanding of what it means to witness for Jesus Christ. And I would like to have us consider this topic of Christian witness in the setting of the example of Jesus in the way le witnessed of is father's love to Zacchaeus in Jericho.

FROF: Every Christian can learn to witness for Cod T.S.: by following the example of Jesus in Luke 19:1-10.

I. JESUS' EASIS CRIENTATION TO LIFE WAS TO SEEK AND SAVE TH LO LOST. LUKe 19:10

1. Because of His basic life style He was able to witness to all classes of people:

a. Regardless of their station in life: rich or poor; community leaders or comimon folk.

b. At all times--from early morning until way into the night

c. In all places-mount of olives, Temple in Jerusalem, walkirg trrough the streets of Jericho, in someone's home for dinner, riding in a boat on the Sea of Galilee.

II. JESUS' LIFE SHOWS TSAT WITNESS IS AN EXPERIENCE RATHER THAN AN ACTIVITY

1. A ritness in a court of $1 a$ is one who has seen and heard. An eye witness. One who can bear a first hand account. If you know Jesus personally you can be a witness. But if you don't know Him you cannot be one. You can be a reflector of someone else's experience but you cannot be as effective as if you were one who is personally involvec.

III. WE TCDAY CAN EXFERTMUCE WITNESS AS A LIFE STYLE LIKE JISUS IF OUR EXFERIENCE WITH THE LCRD IS A DIRECT ONE LIKE LIS

1. My brother phoned from California. He had been reading a book by Hal Iindsey called The late Great Flanet Earth. His phone call gave me an opportunity to witness to him when $I$ was least expecting to do so.

CONC: Cetting to know Jesus is a growing experience. Becoming a Christian witness is also a growing experience. One grows out of the other. To be a Christian is to be a witness. It is not just something we do at isolated times and in irregular places, but it is interwoven with all we do and say are, at all times and in all places. To be like Jesus in all things is our goal. He supplies the power to accomplish it. 
VERBATIM SUMMARY OF EVALUATION SHEETS

FILLED OUT ON SUNDAY, OCTOBER 12,1975

QUESTION 1: What happened in the Seminar that was the most helpful to you?

I very much enjoyed the interaction between individuals - the chance to hear other's topics was more meaningful than another - I found them all helpful and thought provoking.

The sharing of ideas and concepts re: discipline and witnessing.

Having the viewpoints of other people both adults and younger members of families and participation of all members in most activities. Especially appreciated the isolated setting which added to the effectiveness of the program.

Honest open sharing between individuals, insights into how others dealt with problems or situations, the variety of experiences and viewpoints, the opening session was very important in helping us to know and understand each other.

The discussion of youth and adults together.

Sharing insights with other parents. Thought about loving others as Christ loves us. Recognized my lack of love in dealing with cantankerous (sic) people.

The group interaction and sharing of experiences creating an openness and bond between the families; having someone working with the children.

a. Presentation of Deut 6:17 on Love of God and discussions on how to cultivate this love - tuning in to know what a person is really trying to say, b. Ideas of improving personal devotions, c. Group participation on communication.

The discipline session and the volley ball.

I enjoyed communication the best, for this is my problem and our family's problem. To hear how others handle the problem. Witnessing. It took me a long time to get over feeling guilt about not going door to door to witness. The Lord has taught me that I was witnessing through my life and work also.

Preacher got some pre-structured material with no change in the format possible for alternative choices in the mainstream of ideas.

The opportunity to get together to share ideas on faith, how to be better parents, etc. 


\section{5}

The teenager discussion.

Listening to others comments on how to improve the home.

The communication part.

It helped me learn to better cope with family situations.

I think the last where the kids got together and talked would have been the most helpful except we didn't have enough time.

Group discussions on discipline, worship, etc.

Every item helpful.

I don't know.

QUESTION 2: What happened in the Seminar that was the least helpful to you?

Recreational period.

The communicating games - because the structured situations were not that real for several couples involved and certain degrees of skill in communicating were already in practice by certain couples.

Listening to [A participant was named here] put in sometimes cynical, unrelated remarks which were not really dampered by the leader or others in a very outspoken manner.

Solving children's problems since my children are older. Although some things were brought out that helped with older children.

Free wheeling, mystified notions that our SDA church has actually no problems or fallings out when $50 \%$ of our SDA youth leave the church after attending SDA schools.

Some of the discussions I couldn't seem to get involved in.

The communication meeting.

The discipline part.

Communication games - did not really make a realistic situation.

Games .

QUESTION 3: What suggestions would you have to improve the Seminar?

Suggest a little more use of audio-visual materials. Also would see a need for additional follow-up. 
Improvement could be to plan more family unit involvement and planning by possibly lengthening the Seminar or cutting back some discussion.

Have a longer period of time so to have a little more breaks.

More visual aids, inc. handouts. More small group activities. More frequent breaks for short periods of time. Printed handouts could be of uniform medium type and facing one direction for notebook readability.

Continue having group interaction where poss. rather than just the family unit. Have the Seminar all day Sat \& Sun. instead of Sun. noon.

Perhaps privately we could jot down a list of 4 or so things we would like to discuss regarding children. Paraphrasing \& listening exercise would be more meaningful if real situation and persons involved willing to share.

When hands are raised, to give them a chance to speak also. Only the aggressive one's had a chance to speak.

Part of the way people learn is to contribute to the restructuring of pre-fabricated highly structured views of the SDA home. Christian Service p. 41 says 1 in 20 SDA's will ever reach the point they are preparing to have heaven on earth in their homes. Written comments need evaluation not just being handed out.

Would like to have had more time to be in a small group with perhaps just 1 other family to discuss various problems. Ideas are usually shared under such conditions which may not be revealed in the larger group.

Have more time for teenagers, maybe a little more free time.

Visual aids, more time.

Prior to Seminars, have people write out specific problems - so we can be specific without wasting time.

QUESTION 4: Comments you would like to share.

Would like to see more church members involved in later Seminars.

Perhaps conduct separate sessions for families with teenagers and families with pre-teen children, although both can be mutually helpful.

These should grow into the church at large. Overall we had a relative high caliber of families here. My question would be how would less spiritual and more troubled families react. My guess is that it might be a more helpful more spectacular in results because growth might be at a more critical level and extent. 
Enjoyed this experience tremendously \& know I will look back to it as a turning point in at least 2 learning situations in my life.

I appreciated the stimulation of the discussions $\&$ when we are forced to face areas that we may be-uncomfortable with - the way growth occurs.

I enjoyed being with everyone even though I don't mix well with a group. I still like being together. I have enjoyed the whole week end - listening to the youth, I enjoyed because it gave me a better look into the young. Sometimes we don't see our youth's problems.

A tenacious retention of personal home experiences segregates the scope and content to many areas of thought which demand expertise to make a relatively dull subject vital to us.

I have received many ideas \& thoughts on how I can improve my relations with members of my family, other adults $\&$ particularly in the classroom, such as being more consistent, etc.

I think you got my attention more when you gave demonstrations because it was something I could attach to.

I learned a great deal here. I was happy to meet the people (a few exceptions). members.

I felt uncomfortable expressing opinions in presence of family

Excellent overall.

Excellent.

QUESTION 5: Overall evaluation: (Please check one)

$\begin{array}{lr}\text { Excellent } & 14 \\ \text { Good } & 4 \\ \text { Fair } & 0 \\ \text { Poor } & 1 \\ & 1 \text { no response } \\ & 20 \text { TOTAL }\end{array}$




\section{Hemet Seventh-day Adventist Church}

125 N. THOMPSON STREET

- HEMET, CALIFORNIA 92343

658.2632

OFFICE OF THE PASTOR

PASTORAL NEWSLETTER

OCTOBER, 1975

DEAR MEMBERS AND FRIENDS:

THE LORD HAS SURELY BLESSED OUR CHURCH LAST MONTH. THE COMPLETION OF OUR NEW SCHOOL BUILDING, THE SUCCESSFUL 5-DAY PLAN TO STOP SMOKING, THE BAPTISM OF MRS. FAYE WOODS AND OUR COMMUNION SERVICE ARE LISTED, JUST TO NAME A FEW.

THE MONTH OF OCTOBER, WHICH IS NOW BEGINNING, ALSO HOLDS IN STORE FOR US MANY ADDITIONAL BLESSINGS FROM THE LORD. THESE WILL BE LISTED BRIEFLY. FIRST, THEN WE WILL AMPLIFY THE ONE MARKED (*) IN PARTICULAR.

PRAYER MEETINGS: AT 7:30 P.M. EACH WEDNESDAY WE WILL CONTINUE OUR PRAYER FELLOWSHIP AND STUDY OF THE BOOK OF ACTS.

WORSHIP SERVICES:

OCTOBER 4 ELDER COWAN, "THINGS NEW AND OLD, PART II".

* october 11 elder cowan, pine springs ranch, family sfiritual ENRICHMENT SEMINAR. GUEST SPEAKER IN HEMET. OCTOBER 18 PASTOR PAPENDICK WILL PRESENT THE SERMON. OCTOEER 25 ELDER COWAN, "REVERENCE".

SABBATH EVENING VESPERS:

OCTOBER 4 AT 6:OO P.M. DAVID ATWOOD, TENOR SOLOIST, WILL PRESENT A SACRED MUSICAL CONCERT.

OCTOBER 18 AT 6:00 P.M. ELDER WILLIAM BARCLAY WILL PRESENT THE NARRATED FILM, "INDIA".

OCTOBER 25 AT 6:00 P.M. ELDER WILLIAM BARCLAY WILL PRESENT THE NARRATED FILM, "(CEYLON) SRI LANKA AND PAKISTAN".

PATHFINDER CAMPOUT: OCTOBER 3-5, STARDUST RANCH

NOMINATING COMMITTEE: PROCESS OF SELECTION TO BEGIN OCTOBER 4.

SCHOOL BOARD MEETING: MONDAY, OCTOBER 6, 7:00 P.M. AT THE NEW SCHOOL.

* family spiritual enrichment seminar: october 10-12, pine springs RANCH. SEE APPLICATION ENCLOSED.

HOME AND SCHOOL MEETING: 7 P.M. MONDAY, OCTOBER 13, at THE NEW SCHOOL.

FELLOWSHIP POTLUCK DINNER: AFTER THE WORSHIP SERVICE, SABBATH, OCTOBER 18, AT THE NEW SCHOOL, 26312 SO. HEMET ST., HEMET.

PATHFINDER FAIR: SUNDAY, OCTOEER 19, DEL MAR FAIRGROUNDS IN SAN DIEGO COUNTY. 
PASTORAL NEWSLETTER

OCTOBER, 1975

PAGE 2

Now that you have an overview of the church calendar for october, let us en-

LARGE ON THE FAMILY SPIRITUAL ENRICHMENT SEMINAR.

THIS PART OF THIS LETTER IS INTENDED TO CONVEY A CORDIAL INVITATION TO THE MEMBERS OF THE. HEMET SEVENTH-DAY ADVENTIST CHURCH TO ATTENO "HOME: THE SCHOOL OF LOVE", A SEMINAR IN FAMILY SPIRITUAL ENRICHMENT, TO BE CONDUCTED BY ELDER ROBERT COWAN AT PINE SPRINGS RANCE FROM FRIDAY THROUGH SUNDAY, OCTOBER 10-12.

WHO MAY ATTEND? ANY HEMET CHURCH MEMBER OR FRIEND WHO WANTS TO, PROVIDING THEY INTEND TO BE PRESENT FOR THE ENTIRE SEMINAR. THE MEETINGS WILL BEGIN ON FRIDAY NIGHT AND END ON SUNDAY AFTERNOON. JUST TO VISIT THE SEMINAR ON SABBATH MORNING OR AFTERNOON IS NOT BEING ENCOURAGED. REGISTRATION INVOLVES A COMMITMENT TO A FULL ATTENDANCE AT ALL OF THE SEMINAR MEETINGS.

FOR WHOM IS IT DESIGNED? ADVENTIST FAMILIES. THIS WILL GENERALLY INCLUDE THE YOUNGER FAMILIES WITH CHILDREN STILL IN THE HOME. HOWEVER, MARRIED COUPLES (OF EITHER RECENT OR LONG-TERM STANDING), SINGLE ADULTS (FOR WHATEVER REASON -UNMARRIED, WIDOWS, WIDOWERS AND DIVORCEES) WILL NOT BE EXCLUDED IF THEY WISH TO ATTEND.

WHAT IS THE PURPOSE OF THE SEMINAR? TO PROMOTE THE SPIRITUAL GROWTH OF EACH PARTICIPANT IN HIS LOVE FOR GOD, THE MEMBER'S OF ONE'S FAMILY AND FOR ALL OTHERS OUTSIDE OF ONE'S FAMILY.

COST OF THE SEMINAR

LODGING: \$2.50 PER NIGHT PER PERSON OR \$6.00 PER FAMILY PER NIGHT.

MEALS: \$1.15 PER MEAL EXCEPT SABBATH NOON AT \$1.40. CHILDREN AGES 1-4 FREE. SEMINAR MATERIALS: \$2.00 PER FAMILY FOR PRINTED MATERIALS TO BE USED.

CHILD CARE: THERE WILL BE CHILD CARE PROVIDED DURING THE SEMINAR MEETING HOURS FOR CHILDREN BELOW THE AGE OF 12. CHILDREN 12 AND ABOVE ARE ENCOURAGED TO PARTICIPATE IN THE SEMINAR.

DEADLINE FOR REGISTRATION: SUNDAY, OCTOBER 5, AT 5:00 P.M. PLEASE FILL OUT THE ENCLOSED APPLICATION ANO RETURN IT TO THE CHURCH OFFICE WITH YOUR REMITTANCE BY THE DEADLINE.

IT IS MY HOPE THAT ALL OF OUR FAMILIES WITH CHILDREN AND AS MANY OTHERS AS WISH TO DO SO WILL ATTEND.

PLEASE JOIN ME IS PRAYER FOR A SPIRITUALLY UPLIFTING SEMINAR.

YOURS FOR STRONGER. FAMILIES IN CHRIST,

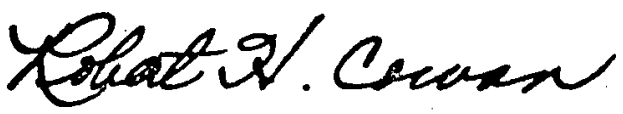

ROBERT H. COWAN

PASTOR

RHC / EP

ENCLOSURE 
"HOME, THE SCHOOL OF LOVE"

A. FAMILY SPIRITUAL ENR ICHMENT SEMINAR

OCTOBER $10-12,1975$

APPLICATION FOR REGISTRATION

INSTRUCTIONS PLEASE FILL IN THE BLANKS BELOW AND RETURN TO THE CHURCH OFFICE BY SUNDAY, OCTOBER 5 AT 5:00 P.M. ONE APPLICATION FOR EACH FAMILY IS ADEQUATE. A $\$ 2.00 \mathrm{FEE}$ IS CHARGED TO COVER THE COST OF SEMINAR MATERIALS ALONG WITH THE MEALS AND LODGING CHARGES FOR PINE SPRINGS RANCH.

NAME PHONE

ADDRESS ZIP

CHECK ONE OF THE FOLLOWING IN EACH CATEGORY

MALE

FEMALE

AGE () BELOW 20 ( ) 21-40 ( ) 41-60 ( ) ABOVE 60

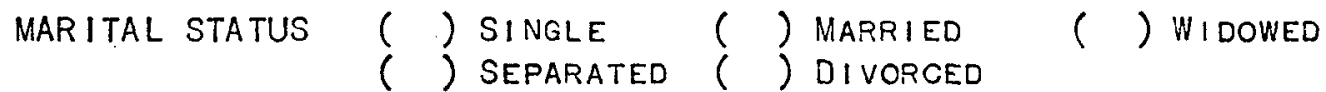

IF MARR IED, NAME OF SPOUSE

AGE OF SPOUSE, IN RELATIONSHIP. TO MY AGE:

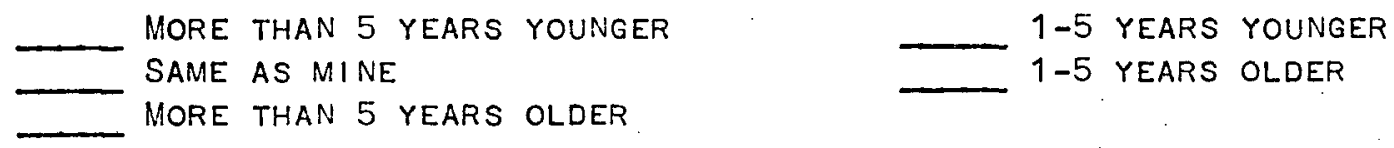

IF yOU HAVE CHILDREN, PLEASE COMPLETE THE FOLLONING --USE BACK OF SHEET, IF NECESSARY NAMES AGES YEAR IN SCHOOL SCHOOL ATTENDING

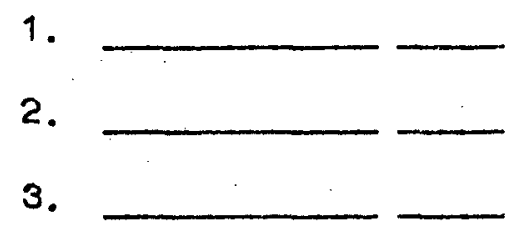

CHURCH AFFILIATION SDA NONE OTHER, PLEASE SPECIFY 1 HEARO ABOUT THIS SEMINAR IN THE FOLLOWING WAY: (PLEASE SPECIFY) MY GOALS AND EXPECTATIONS FROM THIS SEMINAR ARE (PLEASE LIST IN ORDER OF PRIOR!TY) 1. 2. 3. 


\section{Imosecrios:}

Ey the erace of God wo are God's pooplo becauso Jotn $3: 16$ and

Eor. 21: 6-11. That is sod's act of salvation in Jesus christ.

io are an 'kpocalyptic' poplo, or a prophet1c people who have their roots in prophutic boots $11 \%$ janiol ant Revelation. In both theso

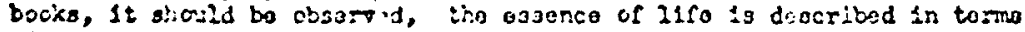
of wCrit?.

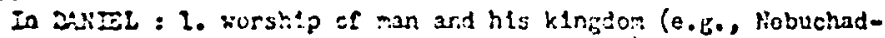
r.cozze ars his Kinidom; Dan.3).

In FarEi. 1 1. worshlp of tho prirco of this werld and his aistrictos, tho knazt, tho 1:-ago of tho beast

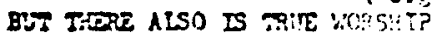
(e.s., Rev. 13).

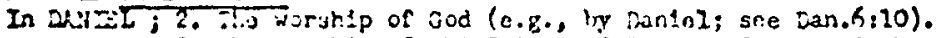

I. $\therefore=$ 2. The woritip of the trinco of Peaco, of God, of tho

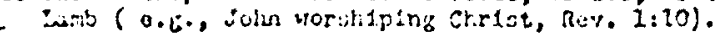

In the bock of Dintel wo sus pityate dovotion of tha sincero in-

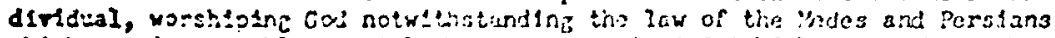

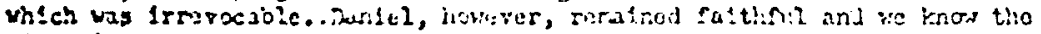
rictorleis outcote of such fesconal derotional life, recorded for us as an exarpic.

In the book of R.avelation he notlce not culy the privato devotion o: ito apestie John (2:20), but ke resd ajout the worsilfp of Gad by the forr

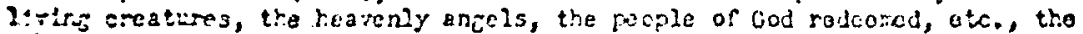
1'i.c.50. Eatwen the exarpla of frtvite tovotien of John ard the worship by

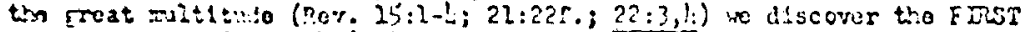

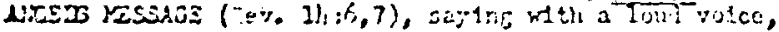
Fear cod and folv itin elery, for the hour of $111 \mathrm{~s}$

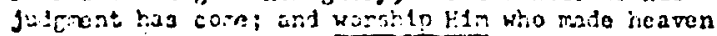
and earth, the sea and fite filliwins or water.

How do we ap:ly "worship him" in cur approitch to tho werld?

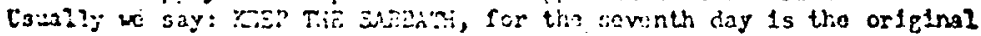

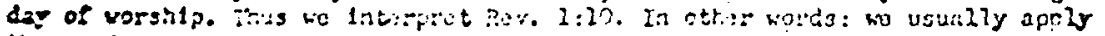

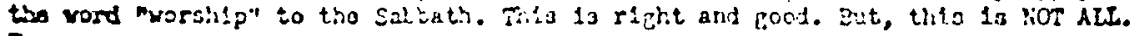
Tor:

1. Wo carnot keep tho Jubbath spiritually unlegs wo knor what salration reans in ol: ilves.

2. It is act oriy on the Satbelit that wo worshlp God for wo ought to worsin! !: in each ar:d eviry day.

Ey so colni, we rereitur thie Sabtath day throughout the weok so that tis Sablath bucoies, in leed, tho epltory, the cilmax, of our trasth-the-rejer- woschis experience.

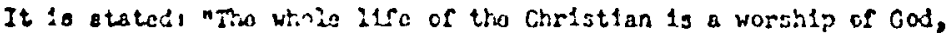

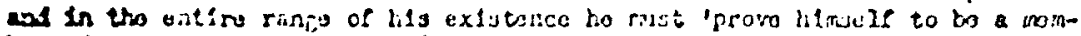
bor of tho Bady of Custat.". (Aranile M. Secler, A Theolary of church and Iinstry, p.IT). 


\section{WhI WE WORZIITP}

Bocause God 1s the Creator of hoavon and oarth.

Besause fod is the Re-creator of ginful man.

God gavo Cirist; Ho is the Inltiator of worship. And wo are exporienclae the woric of sialvat1on in our $\mathrm{cm}$. 1 ves and see God's grace also deacnstrated is thio livos of otters. Illuminated by the Holy Spirit wa aro called to worship 601 throdgh Jesus Christ, our Lord.
"Relleicn is not to bo conetnod to external forms and cerenonios. Tho relition thut corses from ros is tho only relicton that will

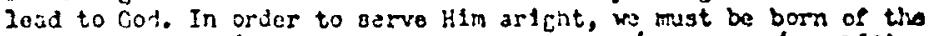 divine Epirit." (E.c. imito, Desire of Azes fspec. od./, p.iso).
"Worjilp is man's reoponve to Go'l's ravolation of himsole." (Frantilin M. Secler, ca. c1t., p. 191)
niod'n merement towards man and min's dependence upon God -. -

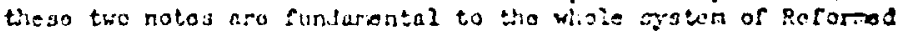

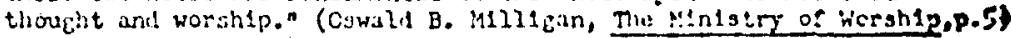

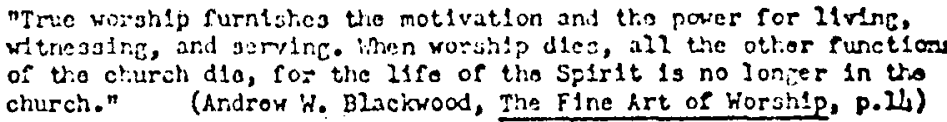

\section{Wiat Is woesu IP}

Rarl Barth writos, "Christian worshtp is the most monentcus, the most urgent, the rost. Elorlous action that can take place in huzin life."

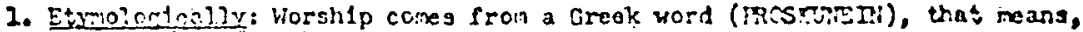
"mrostrate" and "riss". The Ifebres words in tie old festanent have the besie senso "to LCH" ant is also usod for "to kiss," "to serge," "to vorship."

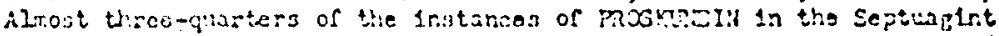

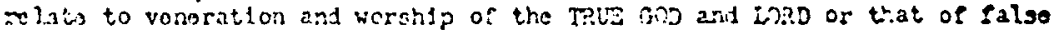
rois.

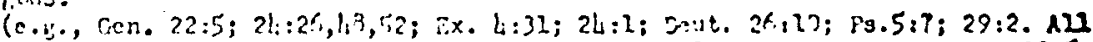

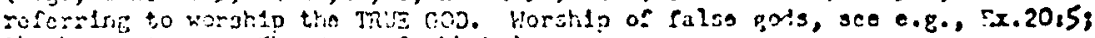

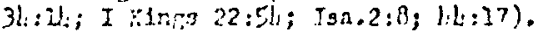

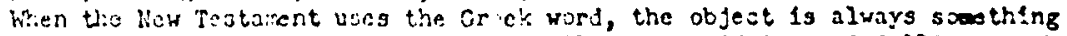
deinos tt expresseo trus ajoration, while the plold ldea ce falling on tho

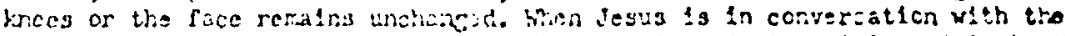

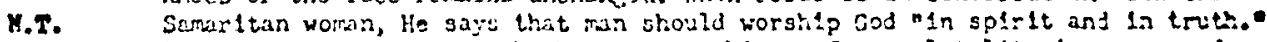

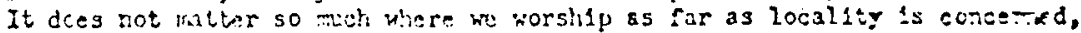

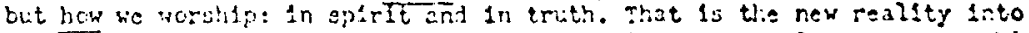
which the son o: Ged alcno sets lis and that is to conirol frayer, worshlp. There is no lcriper to te any oxclisive place of worehip, tit prayse is atill to wike place at spectelc plares and with speciric geitures.

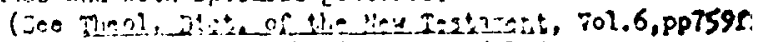

Bonco, Rov. Ih:h-7, "...an! worah!p Him," thint 13, tha Creitor and Reteerer.

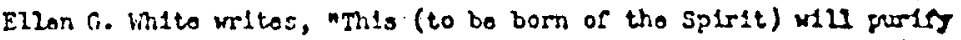
this leart and rorek the mind, riving 133 a now capacity for morts. and loving God. It wizl givo uis a willine oledience to all dis 
expactancy and the warmth of his om sptrit kindied in private devotion." (p.205).

\section{Blackwood:}

K1221gant

"good hab1ts ara the foundation of a good 11fe. Such habits are of tha esserece of pullic worship." (p.77).

"In the despos in which tho Church is the Borig of Chr:st, in the leprec in whteli we as rembers of that Eoly represent in our movernts, in our worsa, and in mir thourtes the rist ant

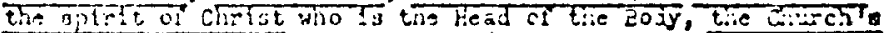

Melutt: Hormit rerlect. thet sams glory. (p.29-30).

* All prayor is woralito, thouph $1 \mathrm{t}$ is not all of worshtp... AII tile conjeious eiforive of man to brtnr hlaself into the presence of rod ars worchtp, wi:12e prayer 13 only one of tho

Garnor: =iorts. $(2.35)$.

"Worship 13 not only an act of adoration and love but an active life of dedication and practical $11 \mathrm{vlng}$, as Ca Ts

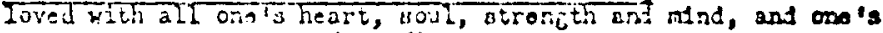
nol.chbor as oneseli." (p.195).

Think of tho serinon thlo past Sabbeth morning and the B1ble toxt

(Dout. 6:L-7; Luke 20:27)

Ellon 0. inits:

"py tiee Spirit overy sincero prayor to Indicated, ant such prarer

is acceptabl. to God. Sherever a soul reaches out acter cod, there

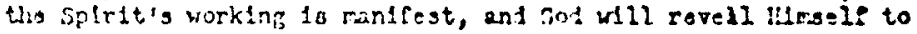
that soul. Ho such worshipars hin is geckinc. He walts to rocelro them ani: to miats then his song anl deughters. (D.A., 151).

In short: Copporets wo:ship must bo an outfrowth of a reglier dally pattern of privats worship.

"Oar Pedeeter th1rsts for rocoinltion. He hingers for syopatiy ent love of those whom to has puechasor xilli lits own blood. tio Icn;s viti in:xpressible destre that they should coos to $\mathrm{rls}$ ali keve lifa. to this rotier waiches for tho entio of rocogn1:100

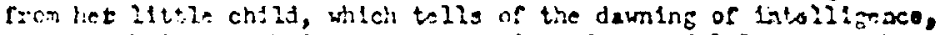
no does Chrlat wateh for the expresslon of grate.ui lore, wich

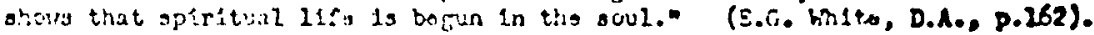

Thls is exactly wilat could and ahould bo dono dalls.

IV. THE PROBLES, and ARE THEY REALIT FOBLES?

1) Wo TLE. Wo 0.11 2ro so tramndouly occupled with prosont-day

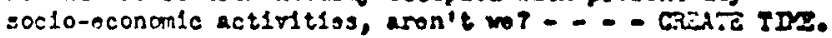

2) FADIRY IS WTI TOCETIER. - - r HAx.

3) DO ROT KNow :rut is Do. 
4) DO NOE ITK A FDCED PATTERN OF DETOR IONAL PROGRANS.

5) WE CAN NOT TALX, WE HAVE NO DAGDUTION

6) SO DTTEREST

7) Prur

8) PLYTLY HARSHIR

9) othor.....

- - - DEotchtion nF spactal thaks

TO DE L.SE DLRAiT THE DAY.

etc., etc.

-. - MACE IT MCRE DRTORYAL Hate

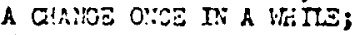
MI:TAIN FaY?

- - - TEN REND TYE DEJTTLOMaLs; WEIL-TREARES; ME IT LTVE. FUT FOR EAOI OTER; SI:ARE Tibugitixs

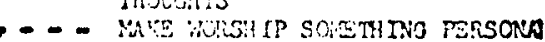
DTEUIITE UHT THS JENN READ ASR EACH OMIER QIESTIOHS.

- - - Midric mara comarcirtoul mayer sich lowes? simallers.

- - - Non uiv patier or Motrer. Li CHTID(MX) Wre T:EIR SAY ABU SAUT EN TEE FALL Wogcitip.

PLAH TUETTER, ROULATE but undor PARENT'S SURERVISION.

\section{To TH'K ABT:}

1. what 1s your concopt of WhGHIP and aro you willing to apply this in your Satily oltuation; how.

2. siculd tho garentis) alrays lesd out in the family worahip or could somono else of the eantly do this.

3. hor do rou 1riteni to plan iantiy vorship; do tho chlldren heve any savine

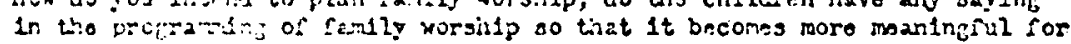

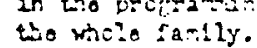

4. Cot together 23 fartilos ard plar cemliz worship for e.g., friday right (a sungot roreh(p): 15 minutos.

5. plan a woretip scieduio for tho last somn sabbatina of the yoar (ounets). 


\section{SELECTED BIBLIOGRAPHY}

\section{Books}

Becker, Russell J. Family Pastoral Care. Englewood Cliffs, N.J.: Prentice-Hall, 1965.

Beigel, Hugo G. Encyclopedia of Sex Education. New York: Wm. Penn Pub. Corp., 1952 .

Berkouwer, G. C. Man: The Image of God. Grand Rapids, Mich.: Wm. B. Eerdmans Pub. Co., 1962.

Blocker, Donald H. Developmental Counseling. New York: Ronald Press Co., 1966.

Brown, Collin, ed. The New International Dictionary of of New Testament. 3 vols. Grand Rapids, Mich.: Zondervan Pub. House, 1976.

Buttrick, Gecrge Arthur. The Interpreter's Dictionary of the Bible. 4 vols. New York: Abingdon Press, 1962 .

Campbe11, Arthur A. ed. The Family in Transition. A Round Table Conference sponsored by the John F. Fogarty International Center for Advanced Studies in Health Sciences. Proceeding No. 3. Bethesda, Md.: National Institute of Health, 1969.

Christenson, Larry. The Christian Family. Minneapolis, Minn.: Bethany Fel1owship, 1970.

Clinebe11, Howard J., Jr., and Clinebel1, Charlotte H. The Intimate Marriage. New York: Harper and Row, Pub., 1970 .

Cooper, David. The Death of the Family. New York: Pantheon Books, A Division of Random House, 1970.

Cooper, Douglas. Living God's Love. Mountain View, Calif.: Pacific Press Pub. Assn., 1975.

Dobson, James. Dare to Discipline. Wheaton, I11.: Tyndale House Pub., 1971.

- Hide or Seek. Old Tappen, N.J.: Fleming H. Revel1 Co., 1974 . 
- What Wives Wish Their Husbands knew about Women.

Wheaton, I11.: Tyndale House Pub., 1975 .

Dodson, Fitzhugh. How to Father. New York: New American Library, Signet Books, 1975.

Eckert, Ralph G. Sex Attitudes in the Home. New York: Association Press, Popular Library Edition, 1963.

Edwards, Josephine C. Children Can Be Taught. Nashville, Tenn.: Southern Pub. Assn., 1960 .

Erickson, Gerald D., and Hogan, Terrance P., eds. Family Therapy: An Introduction to Therapy and Technique. Monterey, Ca1if.: Brooks/Cole Pub. Co., 1972.

Erikson, Erik H. Identity: Youth and Crisis. New York: W. W. Norton \& Co., 1968 .

Fagal, William A., and Fagal, Virginia. Building A Happy Home. New York: Faith for Today, [n.d.].

Fromm, Erich. The Art of Loving. New York: Harper \& Row, Pub., Bantam Books, 1963.

Ginott, Haim G. Between Parent and Child. New York: The Macmillan Co., Avon Books, 1965.

Glasser, William B. Reality Therapy. New York: Harper \& Row, Pub., 1965 .

Gleason, John J., Jr., Growing Up to God: Eight Steps in Religious Development. Nashville, Tenn.: Abingdon Press, 1975 .

Grodon, Thomas. P.E.T.: Parent Effectiveness Training. New York: Peter H. Wyden, Plume Books, 1975.

Guernsey, Dennis. Thoroughly Married. Waco, Tex.: Word Books, Pub., 1976 .

Hine, James R. Alternative to Divorce. Danville, I11.:

Interstate Printers \& Pub., 1957.

Horn, Siegfried H. Seventh-day Adventist Bible Dictionary. Washington, D.C.: Review and Herald Pub. Assn., 1960 .

Huffman, John A., Jr. Becoming A Whole Family. Waco, Tex.: Word. Books, Pub., 1975 . 
Jacobsen, Marion Leach. How to Keep Your Family Together and Still Have Fun. Grand Rapids, Mich.: Zondervan Pub. House, 1973 .

Keniston, Kenneth. Youth and Dissent: The Rise of a New Opposition. New York: Harcourt Brace Jovanovich, A Harvest Book, 1971.

Kittel, Gerhard, ed. Theological Dictionary of the New Testament. 10 vols. Grand Rapids, Mich.: Wm. B. Eerdmans Pub. Co., 1964.

Koller, Marvin R. Families, a Multigenerational Approach. New York: McGraw-Hil1 Book Co., 1974.

La Haye, Tim. How to Be Happy though Married. Wheaton, I11.: Tyndale House Pub., 1976.

La Haye, Tim, and La Haye, Beverly. The Act of Marriage: The Beauty of Sexual Love. Grand Rapids, Mich.: Zondervan Pub. House, 1976.

Landis, Judson T., and Landis, Mary G. Building A Successful Marriage. 6 th ed. Englewood Cliffs, N.J.: Prentice-Ha11, 1973.

Landis, Paul H. Your Marriage and Family Living. 2d ed. St. Louis, Mo.: McGraw-Hi11 Book Co., 1954.

Larson, Bruce. Groups That Work. Grand Rapids, Mich.: Zondervan Pub. House, 1967 .

Leas, Speed, and Kittlaus, Paul. Church Fights: Managing Conflict in the Local Church. Philadelphia: Westminister Press, 1973.

Lee, James Michael. The Shape of Religious Instruction. Mishawaka, Ind.: Religious Education Press, 1971.

Leslie, Robert C. Sharing Groups in the Church: An Invitation to Involvement. Nashville, Tenn.: Abingdon Press, 1971 .

Lewin, S. A., and Gilmore, John. Sex Without Fear. Rev. ed. New York: Medical Research Press, 1962 .

Ligon, Ernest Mayfield. The Psychology of Personality. New York: The Macmillan Co., 1944.

Ligon, Ernest Mayfield, and Smith, Leona Jones. The Marrlage Climate: A Book of Home Dynamics. St. Louis, Mo.: Bethany Press. 
Mace, David R. Hebrew Marriage. London: Epworth Press, 1953 .

- Success in Marriage. Nashville, Tenn.:

Abingdon Press, 1958 .

McGavran, Donald A. How Churches Grow. New York: Friendship Press, 1970 .

McGavran, Donald A., and Arn, Win. How to Grow a Church. Glendale, Calif.: G/L Pub., Regal Books, 1974 .

Merrill, Francis E. Courtship and Marriage. Rev. and ex. ed. New York: Henry Holt \& Co., 1959.

Millet, Genevieve, ed. Guiding Your Child From 5 to 12. New York: Parents' Magazine Enterprises, 1965.

Moore, Raymond S., and Moore, Dorothy N. Better Late Than Early: A New Approach to Your Child's Education. New York: Reader's Digest Press, dist. by E. P. Dutton \& Co., Inc., 1975.

Mudd, Emily Hartshorne, and Krich, Aron, eds. Man and Wife. New York: W. W. Norton \& Co., 1957.

Nichol, Frances D. ed. The Seventh-day Adventist Bible Commentary. 7 vols. Washington, D.C.: Review and Herald Pub. Assn., 1953-1957.

Niebuhr, H. Richard, and Williams, Daniel Day. The Purpose of the Church and Its Ministry. New York: Harper \& Brothers, 1956 .

Ohlsen, Merle M. Group Counseling. New York: Holt, Rinehart and Winston, 1970 .

Palmer, Earl F. Love Has Its Reasons: An Inquiry into New Testament Love. Waco, Tex.: Word Books, Pub., 1977.

Pikunas, Justin. Human Development: A Science of Growth. New York: McGraw-Hill Book Co., 1969 .

Reid, Clyde. Groups Alive--Church Alive: The Effective Use of Small Groups in the Local Church. New York: Harper \& Row Pub., 1969 .

Richards, Lawrence 0 . Sixty-nine Ways to Start a Study Group and Keep it Growing. Grand Rapids, Mich.: Zondervan Pub. House, 1973.

- A Theology of Christian Education. Grand Rapids, Mich.: Zondervan Pub. House, 1975 . 
Schuller, Robert H. Self-Love, The Dynamic Force of Success. New York: Hawthorn Books, 1969 .

Shedd, Charlie W. Lettersto Karen: On Keeping Love in Marriage. Nashville, Tenn.: Abingdon Press, Spire Books, 1973.

- Letters to Philip: On How to Treat a Woman. 01d Tappan, N.J.: Fleming H. Revell Co., Spire Books, 1973.

Sheresky, Norman, and Mannes, Marya. Uncoupling: The Art of Coming Apart, A Guide to Sane Divorce. New York: Viking Press, 1972 .

Sherril1, Lewis H. Guilt and Redemption. Rev. ed. Richmond, Va.: C. D. Deans, 1957.

Shorter, Edward. The Making of the Modern Family. New York: Basic Books, Pub., 1975 .

Shryock, Harold. Happiness for Husbands and Wives. Washington, D.C.: Review and Herald Pub. Assn., 1949.

Shultz, David A., and Wilson, Robert A., eds. Readings on The Changing Family. Englewood Cliffs, N.J.: Prentice-Ha11, 1973 .

Skolnick, Arlene S., and Skolnick, Jerome H. Family in Transition. Boston, Mass.: Little, Brown and Co., 1971.

Smith, Donald P. Clergy in the Cross Fire: Coping with Role Conflicts in the Ministry. Philadelphia: Westminster Press, 1974.

Snaith, Norman Henry. The Distinctive Ideas of the 01d Testament. Philadelphia: Westminster Press, 1974.

Spalding, Arthur W. Love, Courtship and Marriage. Washington, D.C.: Review and Herald Pub. Assn., 1929.

Strommen, Merton P. Five Cries of Youth. New York: Harper \& Row, Pub., 1974.

- ed. Research on Religious Development: A Comprehensive Handbook. New York: Hawthorn Books, 1971 .

Symonds, Percival M. Dynamic Psychology. New York: Appleton-Century-Crofts, 1949 . 
Tenney, Merrill C., ed. The Zondervan Pictorial Encylopedia of the Bible. 5 vols. Grand Rapids, Mich.: Zondervan Pub. House, 1975 .

Tournier, Paul. To Understand Each Other. Richmond, Va.: John Knox Press, 1967.

Towns, Elmer. The Ten Largest Sunday Schools, and what Makes Them Grow. Grand Rapids, Mich.: Baker Book House, 1969 .

Vandeman, George E. Happiness Wa11 to Wa11. Mountain View, Calif.: Pacific Press Pub. Assn., 1968.

Vaughan, Victor V., III, and Vrazelton, T. Berry, eds. The Family--Can It Be Saved? Chicago: Year Book Medical Pub., 1976.

Walton, Richard E. Interpersonal Peacemaking: Confrontation and Third-Party Consultation. Reading, Mass.: Addison-Wesley Pub. Co., 1969 .

White, Ellen G. The Acts of the Apostles. Mountain View, Calif.: Pacific Press Pub. Assn., 1911.

- The Adventist Home. Nashville, Tenn.: Southern Pub. Assn., 1952 .

- Child Guidance. Nashville, Tenn.: Southern

Pub. Assi., 1954 .

- Christ's object Lessons. Washington, D.C.:

Review and Herald Pub. Assn., 1941.

- The Desire of Ages. Mountain View, Calif.:

Pacifc Press Pub. Assn., 1940.

- Education. Mountain View, Calif.: Pacific Press Pub. Assn., 1952 .

- Fundamentals of Christian Education. Nashville, Tenn.: Southern Pub. Assn., 1923.

- The Great Controversy. Mountain View, Calif.: Pacific Press Pub. Assn., 1950.

- The Ministry of Healing. Mountain View, Calif.: Pacific Press Pub. Assn., 1942.

- Patriarchs and Prophets. Mountain View, Calif.: Pacific Press Pub. Assn., 1913. 
- Sons and Daughters of God. Washington, D.C.: Review and Herald Pub. Assn., 1955.

- Testimonies for the Church. 9 vols. Mountain View, Calif.: Pacific Press Pub. Assn., 1948.

- Testimonies to Ministers and Gospel Workers. Mountain View, Calif.: Pacific Press Pub. Assn., 1944 .

Williams, Bertrand. The Christian Boy's Problems. 4 th ed. Grand Rapids, Mich.: Zondervan Pub. House, 1945.

Williams, H. Page. Do Yourself a Favor: Love Your Wife. Plainfield, N.J.: Logos International, 1973.

Young, Robert. Analytical Concordance to the Bible. Grand Rapids, Mich.: Wm. B. Eerdmans Pub. Co., $22 \mathrm{~d}$ American Edition.

\section{$\underline{\text { Periodicals }}$}

Bettelheim, Bruno. "Recreating Family Life: The Means are in Our Hands." Parents' Magazine \& Better Homemaking, October 1976, p. 72 .

Blood, Robert 0. "Research Needs of a Family Life Educator and Marriage Counselor." Journal of Marriage and the Family 38 (February 1976): 10 .

Ensworth, George, Jr. "Biblical Foundations for the Family." Theology, News and Notes 20 (December 1974): 2 .

Mace, David R. "Making Marriage Work." Parents" Magazine \& Better Homemaking, October $1976, \mathrm{p} \cdot 18$.

Roberts, Rita. "A View of the American Family." Viewpoint 7 (Winter 1976): 7 .

Silden, Isobel. "Should You Have Sex with Your Doctor?!" Pageant 32 (January 1977): 48 .

Stoop, David A. "Editorial." Theology, News and Notes 20 (December 1974): 2 .

"The American Family: Future Uncertain." Time, December 28,1970, p. 34 .

"The American Family: Can it Survive Today's Shocks?" U.S. News \& World Report, October 27, 1975, p. 30. 
White, Elien G. Review and Herald, June 10, 1890.

Quoted in Francis D. Nicho1, ed. The Seventh-day Adventist Bible Commentary. 7 vols. Washington, D.C.: Review and Herald Pub. Assn., 1957, 6:1078.

\section{Doctoral Dissertations and Project Reports}

Bender, Ross Thomas. "The Role of the Contemporary Family in Christian Nurture: A Theological Interpretation." Ph.D. dissertation, Yale University, 1962.

Bietz, Gordon G. "The Development and Formative Evaluation of Instructional Materials and Procedures Designed to Teach the Concept of Christian Witness." D.Min. project report, Andrews University, 1976 .

Cox, Samue1 H. "Family Background Effects on Personality Development and Social Acceptance." Ph.D. dissertation, Texas Christian University, 1966.

Doherty, John Frances. "A Study of Change in the Religious and Social Attitudes of 85 Members of the Christian Family Action Movement in a Suburban Parish." Ph.D. dissertation, Fordham University, 1963.

Howe11, Jean Bonner. "A Family Ministry Approach to Christian Education for Southern Baptist Churches." D.R.E. dissertation, Southern Baptist Theological Seminary, 1967 .

Owen, Margaret R. "A Philosophy for Christian Family Life." Ph.D. dissertation, Columbia University, 1952 .

Powe11, Arthur James. "The Influence of Family Life in the Development of Christian Personal Morality." Ph.D. dissertation, Southern Baptist Theological Semin ary, 1963 .

Richards, Lawrence 0. "Pre-evaluative Research on a Church/ Home Christian Education Program." Ph.D. dissertation, Northwestern University, 1972.

Staff, Elwood E. "An Inquiry Into the Needs and Problems of the Seventh-day Adventist One-parent Family." D.Min. project report, Andrews University, 1974.

Stricklin, Ernest. "Christian Family Life Education Implied in the Covenant Life Curriculum of the Presbyterian Church in the United States." Th.D. dissertation, Boston University School of Theology, 1964. 
Youngberg, John B. "A Study of Leadership Concepts and Their Application in Family-life Education Training Courses in a Seventh-day Adventist Community."

Ed.D. dissertation, Western Michigan University, 1974 .

\section{$\underline{\text { Sy } 11 a b i}$}

Gothard, Bill. "The Institute in Basic Youth Conflicts, Basic Seminar." Oak Grove, I11., n.d.

- "The Institute in Basic Youth Conflicts, Advanced Seminar." Oak Grove, I11., n.d.

- "The Institute in Basic Youth Conflicts, Pastor's Seminar." Oak Grove, I11., n.d.

Macaulay, Shirley. "Together Again." 6659 Sunset Circle, Riverside, Calif., n.d.

\section{Tapes}

La Haye, Tim. "The Happy Christian Home." Family Life Sminars, P.0. Box 1299, E1 Cajon, CA 92022 .

Shedd, Charlie. "The Fun Family Forum." Creative Resources, A Division of Word, 4800 West Waco Drive, Waco, TE. 76703 . 
VITA SHEET

\section{Robert Howard Cowan}

August 1977

Born on September 6, 1938 in Rochester, New York, Robert Cowan was the second of three children. He has an older sister and a younger brother. His early childhood family had no specific church connections.

His family moved to Buffalo, New York, when he was of preschool age, to Pacoima, California, when he was six years old, and one year later to China Lake, California, at which places he attended elementary schools.

During his eighth grade year he first attended a Seventh-day Adventist school as a boarding student at Newbury Park Academy in California. He also attended the ninth grade there. His tenth grade year was taken at Monterey Bay Academy, and the last two years of his secondary education were at James Like High School, San Jose, California, where he was graduated in 1956.

He had attended the University of California at Davis for three and one-half years with a Range Management major, when he transferred to Pacific Union College. Three years later, in 1963, he was graduated from P.U.C. with a B.A. degree in Theology. He was graduated from Andrews 
University with a Master of Arts Degree in 1964. He was married to Janet Louise Clift in 1961, and they have two children.

A11 of his ministry has been within the southeastern California Conference of Seventh-day Adventists where he has served as an associate evangelist in the Loma Linda area, associate pastor in Arlington, pastor of the Lakeside, San Marcos, and Corona churches before becoming pastor of the Hemet church in 1975 .

He was ordained to the Gospel ministry in 1970 by the Southeastern California Conference of Seventh-day Adventists. 